\title{
Flora da RESERVA DUCKe, AMAZONAS, BRASIL: RUdiaceae
}

\author{
Charlotte M. Taylor ${ }^{1}$, Marina T. V. A. Campos $^{2} \&$ Daniela Zappi ${ }^{3}$
}

Rubiaceae Juss., Gen. Pl. 196. 1789.

Andersson, L. 1992. A provisional checklist of neotropical Rubiaceae. Scripta Bot. Belg. 1: 1-199.

Andersson, L. \& Taylor, C. M. 1994. Rubiaceae-Cinchoneae-Coptosapelteae. In: G. Harling \& L. Andersson (eds.). Flora of Ecuador 50: 1-114. Council for Nordic Publications in Botany, Copenhagen.

Andersson, L. 1997. Synopsis of the genus Ladenbergia (Rubiaceae). Nordic J. Bot. 17: 255-299.

Boom, B. M. 1984. A revision of Isertia (Isertieae: Rubiaceae). Brittonia 36(4): 425-454.

Boom, B. M. \& Campos, M. T. V. A. 1991. A preliminary account of the Rubiaceae of a Central Amazonian terra firme forest. Bol. Mus. Emilio Goeldi, ser. Bot. 7(2): 223-247.

Boom, B. M. \& Delprete, P. G. 2002. Rubiaceae. In S. A. Mori; G. Cremers; C. Gracie \& J. D. Mitchell (eds.). Guide to the Vascular Plants of Central French Guiana, Part 2. Dicotyledons. Mem. New York Bot. Gard. 76: 606-649.

Campos, M. T. V. \& Brito, J. M. 1999. Rubiaceae. In J. E. L. S. Ribeiro; M. J. G. Hopkins; A. Vincentini; C. A. Sothers; M. A. S. Costa; J. M. Brito; M. A. D. Souza; L. H. P. Martins; L. G. Lohmann; P. A. C. L. Assunção; E. C. Pereira; C. F. Silva; M. R. Mesquita \& L. C. Procópio. Flora da Reserva Ducke: guia de identificação das plantas vasculares de uma floresta de terra-firme na Amazônia Central. INPA. 798 p.

Delprete, P. G. 1999. Rondeletieae (Rubiaceae) - Part I (Rustia, Tresanthera, Condaminea, Picardaea, Pogonopus, Chimarrhis, Dioicodendron, Molopanthera, Dolichodelphys, and Parachimarrhis). Flora Neotropica Monograph 77: 1-226.

Kinupp, V. F. 2002. Riqueza, abundância e distribuição do gênero Psychotria L. (Rubiaceae) na Reserva Florestal Adolpho Ducke, Manaus - AM. Dissertação de Mestrado. Universidade do Amazonas/INPA, Manaus.

Kinupp, V. F. \& Magnusson, W. E. 2005. Spatial patterns in the understorey shrub genus Psychotria in central Amazonia: effects of distance and topography. J. Trop. Ecol. 21: 363-374.

Kirkbride, J. H., Jr. 1985. A revision of the genus Capirona. Acta Amaz. 15: 47-60.

Persson, C. 2005. New combinations in Kutchubaea (Gardenieae - Rubiaceae). Revista de Biologia Neotropical 2(2): $65-74$.

Prado, A. L. 1987. Revisão taxonômica do gênero Tocoyena Aubl. (Rubiaceae) no Brasil. Dissertação de Mestrado. Universidade Estadual de Campinas, Campinas.

Puff, C.; Andersson, L.; Rohrhofer, U. \& Igersheim, A. 1993. The tribe Schradereae (Rubiaceae) reexamined. Bot. Jahrb. Syst. 114(4): 449-479.

Robbrecht, E. 1988. Tropical woody Rubiaceae. Opera Bot. Belg. 1: 1-271.

Rogers, G. K. 1984. Gleasonia, Henriquezia and Platycarpum (Rubiaceae). Flora Neotropica Monograph 39: 1-134.

Müller, J. 1881-1888. Rubiaceae. In C. F. P. von Martius (ed.). Fl. bras. 6(5): 1-486. Fleischer, Leipzig.

Schumann, K. 1888-1889. Rubiaceae. In C. F. P. von Martius \& A. G. Eichler (eds.). Fl. bras. 6(6): 1-466. Fleischer, Leipzig.

Steyermark, J. A. 1964. Rubiaceae. In B. Maguire et al. The Botany of the Guayana Highlands, Part VI. Mem. New York Bot. Gard. 12: 178-285.

Steyermark, J. A. 1967. Rubiaceae. In B. Maguire et al. The Botany of the Guayana Highlands, Part VII. Mem. New York Bot. Gard. 17: 230-486.

${ }^{1}$ Missouri Botanical Garden, P.O. Box 299, St. Louis, MO 63166-0299 USA. charlotte.taylor@ mobot.org ${ }^{2}$ School of Foresty and Environmental Studies, Yale University, 205 Prospect Street, New Haven, CT 065117444 USA. marina.campos@yale.edu

${ }^{3}$ Herbarium, Royal Botanic Gardens, Kew, TW93AA, UK. d.zappi@kew.org 
Steyermark, J. A. 1972. Rubiaceae. In B. Maguire et al. The Botany of the Guayana Higlands, Part IX. Mem. New York Bot. Gard. 23: 227-832.

Steyermark, J. A. 1974. Rubiaceae. In T. Lasser. Flora de Venezuela 9: 1-2070. Instituto Botánico, Caracas.

Steyermark, J. A. 1983. The genus Botryarrhena in Venezuela. Ann. Missouri Bot. Gard. 70: 207-208.

Taylor, C. M. 1992. Revision of Cosmibuena (Rubiaceae). Ann. Missouri Bot. Gard. 79: 886-900.

Taylor, C. M. 1994. Revision of Hillia (Rubiaceae). Ann. Missouri Bot. Gard. 81: 571-609.

Taylor, C. M. 1997a. Conspectus of the genus Palicourea (Rubiaceae-Psychotrieae) with the description of some new species from Ecuador and Colombia. Ann. Missouri Bot. Gard. 84: 224-262.

Taylor, C. M. 1997b. Rubiaceae. In: R. Vásquez Martinez. Flórula de las Reservas Biológicas de Iquitos, Perú. Monogr. Syst. Bot. Missouri Bot. Gard. 63: 602-637.

Taylor, C. M. 2004. The neotropical genus Ronabea (Rubiaceae, Lasiantheae). Syst. Geogr. Pl. 74: 35-42.

Taylor, C. M. 2005. Margaritopsis (Rubiaceae, Psychotrieae) in the Neotropics. Syst. Geogr. Pl. 75: 161-177.

Taylor, C. M. \& Campos, M.T.V.A. 1999. A new species of Psychotria subg. Heteropsychotria (Rubiaceae) from the Adolpho Ducke Forest Reserve, Brazil. Novon 9: 118-199.

Taylor, C. M.; Steyermark, J. A.; Delprete, P. G.; Vincentini, A.; Cortés, R.; Zappi, D.; Persson, C.; Costa, C.B. \& Anunciação, E. 2004. Rubiaceae. In J. A. Steyermark; P. E. Berry; K. Yatskievych \& B. K. Holst (eds.). Flora of the Venezuelan Guayana 8: 497-847.

Taylor, C. M. \& Zappi, D. 2006 [publ. 2007]. Rubiaceae (part 5), Tribe 18. Psychotrieae (2). In G. Harling \& C. Persson (eds.). Flora of Ecuador 79: 1-113. Göteborg University, Sweden.

Árvores, arvoretas, arbustos ou ervas, raramente lianas ou epífitas, hermafroditas ou dióicas. Ramos cilíndricos ou 3-4-angulares, às vezes com exsudado resinoso, às vezes habitados por formigas.

Estípulas interpeciolares, curto-unidas ao redor do caule, unidas ao redor do caule numa bainha (i.e. um tubo), raramente intrapeciolares (Capirona, Henriquezia, Isertia) ou unidas num capuz cônico (i.e. caliptradas), de formas variadas, persistentes ou decíduas. Folhas simples, opostas ou verticiladas, inteiras, decussadas ou às vezes dísticas, geralmente pecioladas, glabras ou pubescentes, ocasionalmente com domácias pequenas nas axilas abaxiais das nervuras laterais; nervação terciária às vezes paralela. Inflorescências terminais ou axilares, cimosas, paniculadas, racemiformes, tirsóides, capitadas ou às vezes reduzidas a uma flor solitária, sésseis ou pedunculadas, com brácteas e bractéolas, às vezes bem desenvolvidas e vistosas. Flores bissexuais ou às vezes unissexuais, actinomorfas ou raramente zigomorfas (Henriquezia), freqüentemente distílicas, às vezes protogínicas; cálice gamossépalo, usualmente 4-5-lobado, às vezes com um dos lobos expandido e colorido (Capirona, Chimarrhis, Warszewiczia), comumente persistente no fruto; corola gamopétala, infundibuliforme, tubulosa ou hipocrateriforme, 4-6(-10)-lobado, prefloração valvar, imbricada ou contorta; estames isômeros, 4 6(-10), alternos e adnatos aos lobos da corola, anteras geralmente lineares ou oblongas, basifixas ou dorsifixas, exsertas ou inclusas, raramente loceladas; ovário ínfero ou raramente súpero (Henriquezia, Pagamea), 2(-8)-locular, óvulos 1 a muitos por lóculo; estigma inteiro ou 2-10-partido. Frutos bacáceos, drupáceos ou capsulares, simples ou raramente sincárpicos (Morinda), carnosos ou secos, deiscentes ou não; bagas multisseminadas; drupas com (1-)2(-5) pirênios; cápsulas 2-loculares septicidas, loculicidas ou circunsisas. Sementes (1-)2 a numerosas, de tamanho variável, aplanadas, subglobosas, cilíndricas ou angulosas, aladas ou não; endosperma bem desenvolvido, raramente ausente. 
Rubiaceae é uma das maiores famílias de angiospermas, com cerca de 10.700 espécies distribuídas em cerca de 640 gêneros (Robbrecht 1988). Ocorre em todas as regiões do mundo, mas principalmente nos trópicos. Na Reserva Ducke constitui uma das maiores famílias, com 99 espécies distribuídas em 36 gêneros. Campos \& Brito (1999) listaram, para o guia de identificação, 90 espécies distribuídas em 35 gêneros; três das quais conhecidas apenas através de coletas estéreis e que não puderam ser identificadas, portanto não estão incluídas no presente trabalho. Após a publicação do guia de identificação, várias outras espécies foram coletadas, identificadas e adicionadas ao presente trabalho, como por exemplo cinco espécies de Psychotria levantadas por Kinupp (2002), mostrando a importância da contribuição de coletas especificamente voltadas para esta família na complementação da amostragem da flora.

A maioria das espécies de Rubiaceae são árvores de pequeno porte ou arbustos muito frequientes no subosque. A família pode ser facilmente reconhecida pelas folhas geralmente opostas e pela presença de estípulas interpeciolares. A grande variação nas formas, tamanhos e cores das flores atrai um grande número de polinizadores para a família, sendo que a polinização pelo vento não ocorre no Neotrópico. Os frutos carnosos também variam nas cores e tamanhos, sendo dispersos por pássaros, morcegos ou ainda por pequenos mamíferos. Várias espécies ocorrentes na Reserva Ducke apresentam associações com formigas.

Entre as referências úteis para identificar as Rubiaceae da região estão Andersson (1992), Boom \& Campos (1991), Boom \& Delprete (2002), Müller Argoviensis (1881-1888), Schumann (1888-1889), Steyermark (1964, 1967, 1972, 1974), Taylor (1997b), e Taylor et al. (2004). Os sinônimos citados no presente trabalho são aqueles publicados recentemente, após o checklist de Andersson (1992). Como em qualquer tratamento florístico, foram encontradas dificuldades com a disponibilidade de material fértil coletado na área de estudo. Muitas espécies foram coletadas apenas em flor ou em fruto, e as descrições das estruturas não vistas na Reserva Ducke foram elaboradas utilizando material herborizado originário da região amazônica disponível nos herbários MO e K, juntamente com as floras e monografias citadas acima.

Achamos interessante estabelecer certos parâmetros para a terminologia utilizada no presente trabalho, especialmente no que diz respeito às estípulas, cálice e frutos. Existem diversas concepções para esses termos na literatura relacionada às Rubiaceae, portanto é importante estabelecer o seu significado em tratamentos taxonômicos.

As estípulas em Rubiaceae são interpeciolares, ou seja, aparecem ligando os pecíolos das folhas opostas (ou às vezes verticiladas), e a observação de estípulas intactas é mais fácil nos nós superiores ou mesmo no ápice dos caules. Em alguns casos (Henriquezia, Capirona, Isertia), as estípulas podem estar unidas na parte interna do pecíolo (fig. 1d), e são denominadas intrapeciolares. As estípulas podem ser livres (fig. 3f) ou unidas por uma bainha, que pode ser truncada (fig. 1g), bi-lobada (fig. 3b, 3d) ou mesmo aristada (fig. 1k).

O termo "cálice" foi usado para designar a parte livre do cálice, ou seja, aquela situada acima do ovário (ou hipanto), variando de muito curto a bem desenvolvido, podendo apresentarse truncado, denteado ou lobado.

O termo "drupa" foi usado para frutos suculentos comportando geralmente dois pirênios (como no caso da maioria das Psychotrieae), ou até cinco (ex. Isertia), ou mesmo um, como ocorre em Faramea e Coussarea. Nos frutos drupáceos as sementes encontram-se protegidas por um endocarpo geralmente rígido, mas que pode apresentar-se até papiráceo ou membranáceo, como no caso dos pirênios solitários de Faramea e Coussarea. 


\section{Chave para os Gêneros de Rubiaceae na Reserva Ducke}

1. Ervas ou lianas herbáceas.

2. Lianas volúveis geralmente com folhas abaxialmente alvas, corola externamente hirsuta 31. Sabicea

2'. Ervas eretas ou prostradas, folhas verdes a pardas na face abaxial, corola externamente glabra a pubescente.

3. Ervas prostradas, com raízes na região dos nós, folhas basalmente cordadas; frutos drupáceos, carnosos.

4. Frutos roxos ou vermelhos

4'. Frutos azuis

3'. Ervas eretas ou decumbentes, desprovidas de raízes na região dos nós, folhas basalmente agudas; frutos capsulares ou mericarpos secos.

5. Estípulas livres, interpeciolares, triangulares, agudas a acuminadas, com margem inteira; corola 5-6-mera, 15-30 mm compr., rosa

5'. Estípulas com bainha unida aos pecíolos, arredondada até truncada, com margem setosa; corola 4-mera, até $5 \mathrm{~mm}$ compr., alva 34. Spermacoce

1'. Arbustos, arvoretas, árvores ou lianas lenhosas ou com caule suculento e espessado.

6. Estípulas bilobadas.

7. Estípulas intrapeciolares; frutos multisseminados; corola com mais de $2,5 \mathrm{~cm}$ compr.

8. Corola zigomorfa; ovário parcialmente a completamente súpero; pecíolos com glândulas na base; sementes $40-45 \mathrm{~mm}$ compr.

14. Henriquezia

8'. Corola actinomorfa; ovário ínfero; pecíolos sem glândulas; sementes 1-8 mm compr.

9. Árvores com casca esfoliante, desprendendo-se em placas arredondadas; cálice com um lobo expandido; frutos capsulares, secos

4. Capirona

9'. Arvoretas ou arbustos sem casca esfoliante; lobos do cálice todos iguais; frutos drupáceos, suculentos

17. Isertia

7'. Estípulas interpeciolares; frutos com 2-5 pirênios unisseminados; corola geralmente menor que $2,5 \mathrm{~cm}$ compr.

10. Inflorescências axilares

23. Morinda

10'. Inflorescências terminais.

11. Corola com tubo dilatado na base; inflorescências e flores geralmente amarelas, vermelhas ou rosadas

11'. Corola com tubo estreito na base; inflorescências e flores geralmente verdes, alvas ou creme.

12. Frutos alaranjados ou roxos

22. Margaritopsis

12 '. Frutos azuis, alvos ou negros

27. Psychotria

6'. Estípulas inteiras (agudas, aristadas, obtusas, arredondadas ou truncadas, interpeciolares ou unidas em um tubo ou capuz).

13. Ovário súpero

24. Pagamea

13. Ovário ínfero.

14. Estípulas unidas em um capuz cônico, seríceas, caducas.

15. Flores pistiladas e frutos agrupados em inflorêscencia

2. Amaioua

15'. Flores pistiladas e frutos solitários

10. Duroia

14'. Estípulas interpeciolares, caducas ou persistentes, glabras ou pubescentes.

16. Estípulas laciniadas na margem ou abaxialmente apendiculadas ... 30. Rudgea

16'. Estípulas agudas, acuminadas, obtusas ou arredondadas, não laciniadas ou apendiculadas (melhor observadas no ápice dos ramos). 
17. Estípulas no ápice dos ramos firmemente convolutas e torcidas, agudas até acuminadas.

18. Flores sem lobos calicíneos expandidos e petalóides; cápsulas $15-45 \mathrm{~mm}$ compr.

12. Ferdinandusa

18'. Flores às vezes com lobos calicíneos expandidos e petalóides; cápsulas 2-10 mm compr. 19. Inflorescências axilares

5. Chimarrhis

19'. Inflorescências terminais e às vezes produzidas nas axilas superiores

36. Warszewiczia

17'. Estípulas no ápice dos ramos complanadas, imbricadas ou abertas, não torcidas, agudas, aristadas ou obtusas até arredondadas.

20. Inflorescências axilares.

21. Frutos secos, capsulares

28. Remijia

21'. Frutos drupáceos, carnosos.

22. Folhas com a venação terciária não paralela

29. Ronabea

22 '. Folhas com a venação terciária paralela.

23. Estípulas agudas

6. Chomelia

23 '. Estípulas obtusas até arredondadas

21. Malanea

20'. Inflorescências terminais.

24. Plantas dióicas com flores unissexuais.

25. Corola com 8-10 lobos, tubo 3-6 cm compr.

19. Kutchubaea

25'. Corola com 4-6 lobos, tubo 1,3-2,8 cm compr.

26. Corola com o tubo constrito abaixo dos lobos

7. Cordiera

26'. Corola com o tubo reto.

27. Caule geralmente resinoso no ápice

1. Alibertia

27 '. Caule não resinoso

16. Ibetralia

24'. Plantas com flores bissexuais.

28. Plantas trepadoras ou epífitas, geralmente suculentas; sementes orbiculares, não aladas.

29. Frutos carnosos

32. Schradera

29'. Frutos capsulares, secos, sementes aladas

30. Flores em grupo de 3-5; corola com os lobos imbricados, sementes glabras

8. Cosmibuena

30'. Flores solitárias; corola com lobos convolutos, sementes comosas .......

28'. Arbustos, arvoretas ou árvores (não epifíticos), não suculentos.

15. Hillia

31. Frutos drupáceos ou bacáceos, com 1-2(-5) sementes ou pirênios.

32. Frutos bacáceos, com sementes solitárias e endocarpo papiráceo.

33. Folhas decussadas; estípulas obtusas a arredondadas .... 9. Coussarea

33'. Folhas dísticas; estípulas obtusas a acuminadas, geralmente aristadas

11. Faramea

32'. Frutos drupáceos, com 2-5 pirênios uniseminados e endocarpo duro.

34. Corola com prefloração contorta; pecíolos articulados na base ....

18. Ixora

34'. Corola com prefloração valvar; pecíolos não articulados 27. Psychotria

31'. Frutos bacáceos ou capsulares, com sementes numerosas.

35. Frutos capsulares, cilíndricos 20. Ladenbergia

$35^{\prime}$. Frutos bacáceos, subglobosos.

36. Inflorescências em espiga ou estreitamente cilíndricas

3. Botryarrhena 
36'. Inflorescências cimosas, arredondadas até largamente piramidais.

37. Corola com prefloração imbricada, sementes angulosas a subglobosas .... 26. Posoqueria

37'. Corola com prefloração contorta, sementes comprimidas 35. Tocoyena

1. Alibertia A. Rich.

Árvores, arvoretas ou arbustos, dióicos. Ramos cilíndricos, às vezes com exsudado resinoso. Estípulas unidas ao redor do caule ou às vezes interpeciolares, persistentes ou decíduas, ovadas ou triangulares. Folhas opostas, pecioladas, decussadas. Inflorescências estaminadas terminais, capitadas, fasciculadas, cimosas ou tirsóides. Flores estaminadas com cálice truncado ou 4-6-denteado; corola hipocrateriforme, alva ou alvo-esverdeada, serícea externamente, serícea na porção distal internamente, lobos 4-6 (-8), prefloração contorta; estames 4-6(-8), inseridos na porção mediana do tubo da corola, anteras dorsifixas; pistilódio semelhante ao estigma; ovário estéril. Inflorescências pistiladas terminais, flores solitárias. Flores pistiladas com cálice e corola semelhantes aos das flores estaminadas ou freqüentemente de tamanho menor e com mais lobos; estaminódios semelhantes aos estames; ovário 3-7-locular, óvulos muitos por lóculo, estigma 3-7-partido. Frutos bacáceos, globosos, carnosos ou coriáceos, geralmente pardos; sementes numerosas, comprimidas, envolvidas numa polpa gelatinosa.

Alibertia compreende cerca de 21 espécies distribuídas do México, América Central e o Caribe até a América do Sul (Taylor et al. 2004), assemelhando-se a Cordiera e Ibetralia.

\section{Chave para as espécies de Alibertia da Reserva Ducke}

1. Folhas glabras em ambas as faces; estípulas 1,7-2,5 cm compr., glabras, persistentes 1. A. claviflora

1'. Folhas com nervuras hirsutas em ambas as faces; estípulas 2,8-4,2 cm compr., hirsutas, decíduas 2. A. hispida

1.1 Alibertia claviflora K. Schum., Fl. bras. 6(6): 387. 1889.

Fig. 1a

Árvores ou arvoretas 7-8 m alt., 7-10 $\mathrm{cm}$ diâm. Tronco circular ou acanalado, base acanalada. Ritidoma marrom claro ou marromavermelhado, finamente estriado, escamoso; exterior da casca marrom, ca. $1 \mathrm{~mm}$ de espessura; casca internamente bege, fibrosa, 1-2 mm de espessura; alburno bege. Ramos marrons, cilíndricos, glabros. Estípulas unidas curtamente ao redor do caule, lanceoladas, persistentes, 1,7-2,5 × 0,7-1 cm, glabras. Folhas pecioladas; pecíolo $2-2,5 \mathrm{~cm}$ compr., glabro; lâmina elíptica, $28-34 \times 14-21 \mathrm{~cm}$, ápice agudo, base obtusa, glabra em ambas as faces; nervuras laterais 9-11 pares. Inflorescências estaminadas subcapitadas, 4-10-floras. Flores estaminadas subsésseis; cálice subtruncado, $8-10 \times 7-8 \mathrm{~mm}$, glabro; corola creme, 6-lobada, 2,5-2,8 cm compr., tubo 4-6 mm larg., externamente serícea. Inflorescências e flores pistiladas não vistas. Bagas solitárias, globosas, 6,5-8,5 $\times$ 7-8,5 cm, coriáceas, glabras.

Esta espécie ocorre na região amazônica, na Colômbia, Equador, Peru, Bolívia e Brasil. Existem problemas de delimitação entre as espécies do gênero. Na Reserva ocorre na floresta de platô, e foi coletada em flor em setembro e em fruto em março e agosto. Campos \& Brito (1999: pág. 645, como Borojoa claviflora).

20.III.1996 (fr) Campos et al. 561 (SPF); 4.IX.1996

(fl) Campos et al. 610 (INPAMO SPF); 31.VIII.1966

(fr) Prance 2136 (INPA K NY).

Material adicional examinado: PERU. LORETO: Maynas, Distr. Sargento Lores, 040. $7^{\prime} 04^{\prime \prime}$, 7255'17' 'W, 116 m, 17.IV.1997 (fl), Vásquez et al. 23346 (K MO). 


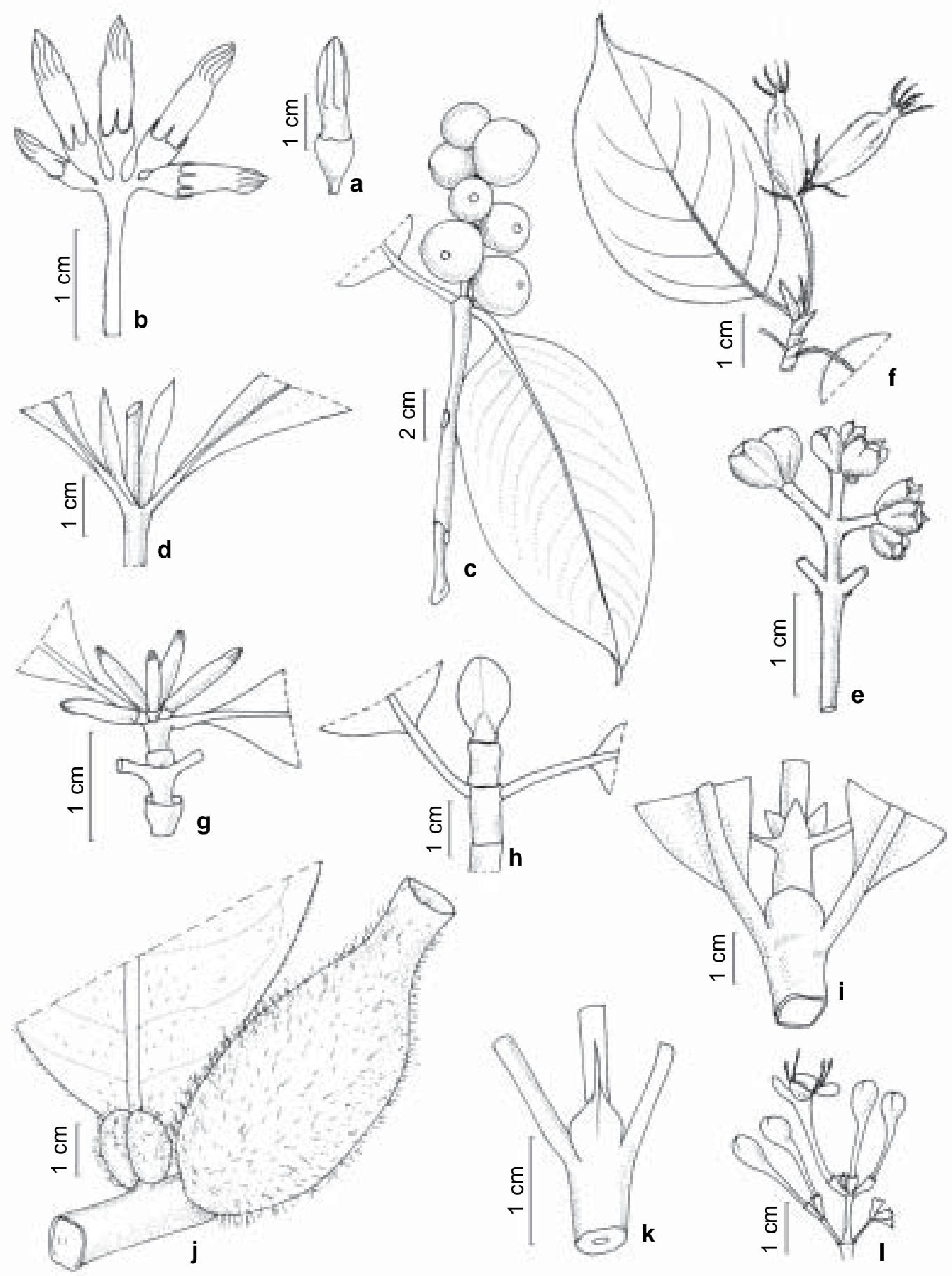

Figura 1 - a. Alibertia claviflora, botão floral (Vásquez 23346); b. Amaioua corymbosa, detalhe da inflorescência masculina (Vicentini 855); c. Botryarrhena pendula, infrutescência (Campos 29); d. Capirona decorticans, estípulas intrapeciolares (Sasaki 1378); e. Chimarrhis barbata, infrutescência (Assunção 369); f. Chomelia estrellana, ramo com frutos (Campos 575); g. Cordiera myrciifolia, inflorescência masculina (Assunção 242); h. Cosmibuena grandiflora, ramo com estípula (Prance 4413); i. Coussarea ampla, parte do ramo mostrando estípulas e gemas laterais (Martins 04); j. Duroia saccifera, fruto e base da folha com domácias (Prance 4689); k. Faramea platyneura, estípula aristada (Sothers 318); 1. Ferdinandusa goudotiana, detalhe da inflorescência (Costa 357). 
1.2 Alibertia hispida Ducke, Notizbl. Bot. Gart. Berlin-Dahlem 11: 481. 1932.

Arvoretas ou árvores, 3,5-10 m alt., 2,5$5 \mathrm{~cm}$ diâm. Tronco circular, base reta. Ritidoma marrom-acinzentado, estriado ou eventualmente fissurado; exterior da casca marromavermelhado, fina, ca. $0,5 \mathrm{~mm}$ de espessura; casca internamente alvo-amarelada a creme, $1-$ $3 \mathrm{~mm}$ de espessura, alburno bege. Ramos cilíndricos, hirsutos, fistulosos. Estípulas interpeciolares, lanceoladas, decíduas, 2,8-4,2× $1-1,4 \mathrm{~cm}$, externamente hirsutas, internamente glabras, margem ciliada. Folhas pecioladas; pecíolo hirsuto, 2,3-4,5 cm compr.; lâmina estreito-lanceolada, 19-32 × 4,3-8,4 cm, ápice agudo a acuminado, base cuneada, esparsamente pubérula na face abaxial, nervuras hirsutas em ambas as faces; nervuras laterais 12-21 pares. Inflorescências estaminadas terminais, cimosas ou tirsóides, até $8,5 \mathrm{~cm}$ compr., subsésseis ou curto-pedunculadas, hirsutas. Flores estaminadas subsésseis ou curtopediceladas; cálice 6-lobado, lobos subulados, 6$8 \times 4-5 \mathrm{~mm}$, hirsutos; corola alvo-esverdeada, esparsamente pubérula, ca. $3 \mathrm{~cm}$ compr., 6lobada, lobos mais longos que o tubo; estames 6 , anteras oblongas. Flores pistiladas solitárias, pedunculadas; cálice e corola semelhantes aos das flores estaminadas. Bagas elipsóides, 9-10 $\times 3,8-4,7 \mathrm{~cm}$, verde-amareladas, hirsutas.

Esta espécie ocorre da Colômbia ao Brasil e Peru. Está incluída provisionalmente dentro do gênero Alibertia. Na Reserva Ducke, ocorre em floresta de baixio e em campinarana. Floresce em dezembro e frutifica de março a maio (Campos \& Brito 1999: pág. 626, 645). 21.XII.1994 (fl), Nascimento \& Silva 678 (INPA, MO, NY, SPF); 15.V.1995 (fr), Cordeiro et al. 1559 (INPA, MO, NY, SFP); 31.V.1995 (fr), Vicentini et al. 986 (INPA MO NY SFP); 23 III. 1995 (fr), Ribeiro \& Assunção 1581 (INPA MO NY SPF).

\section{Amaioua Aubl.}

Árvores ou arbustos dióicos. Ramos geralmente seríceos. Estípulas unidas num capuz cônico sobre a gema terminal, decíduas, seríceas. Folhas opostas ou ternadas, pecioladas, decussadas. Inflorescências estaminadas terminais, geralmente fasciculadas. Flores estaminadas com cálice truncado ou (5-) 6-lobado; corola hipocrateriforme, cremeesverdeada, lobos (5-)6, prefloração contorta; estames (5-)6, inseridos na porção mediana do tubo da corola; anteras dorsifixas; pistilódio semelhante ao estigma; ovário estéril. Inflorescências pistiladas terminais, cimosas ou capitadas. Flores pistiladas com cálice e corola semelhantes aos das flores estaminadas; estaminódios semelhantes aos estames; ovário 2-locular, óvulos muitos por lóculo, estigma 1-partido. Frutos bacáceos, elipsóides ou subglobosos, carnosos, negros ou roxos; sementes numerosas, achatadas, envolvidas numa polpa gelatinosa.

Este gênero compreende cerca de sete espécies, ocorrendo na sua maioria na América do Sul (Taylor et al. 2004), reconhecido pelas estípulas caliptradas, inflorescências terminais, compactas com flores unissexuais e bagas com muitas sementes. Amaioua é um gênero próximo de Duroia. Apesar de tradicionalmente aceitas (Steyermark 1964, 1974), as duas espécies de Amaioua tratadas aqui são de difícil diferenciação e necessitam ser estudadas de modo mais aprofundado para verificar se são mesmo espécies diferentes ou trata-se de variação morfológica.

\section{Chave para as espécies de Amaioua da Reserva Ducke}

1. Bagas pedunculadas; folhas com as nervuras laterais 9-11 pares

1. A. corymbosa

1'. Bagas sésseis; folhas com as nervuras laterais 8-16 pares

2. A. guianensis 
2.1 Amaioua corymbosa Kunth, Nov. Gen. Sp. 3: 419, t. 294.1818 [publ. 1820].

Fig. 1b

Árvores ou arvoretas até $20 \mathrm{~m}$ alt., 30 cm diâm. Tronco sulcado. Ritidoma marrom escuro, fissurado; exterior da casca marrom, ca. $2 \mathrm{~mm}$ de espessura; casca internamente marrom claro, ca. $2 \mathrm{~mm}$ de espessura; alburno bege. Ramos cilíndricos, glabrescentes. Estípulas caliptradas, lanceoladas, externamente seríceas, internamente glabras, até $1,5 \times 7 \mathrm{~mm}$. Folhas opostas, decussadas, pecioladas; pecíolo 2,5-3 cm compr.; lâmina lanceolada a elíptica, $18-20 \times 9-10 \mathrm{~cm}$, ápice agudo, base cuneada, glabra em ambas as faces, nervuras tomentosas na face abaxial; nervuras laterais 9-11 pares, impressas na face adaxial. Inflorescências estaminadas pedunculadas, tomentosas, multifloras, 2,7-3,7 cm compr. Flores estaminadas alvas a creme; cálice 6-lobado, 6-7 × 3-4 mm; corola 6-mera, 1,2-1,5 × 0,2$0,3 \mathrm{~cm}$, serícea. Inflorescências pistiladas pedunculadas, $2,5-3,5 \mathrm{~cm}$ compr. Flores pistiladas pediceladas; cálice 6-lobado, 2,5-4 $\times 0,2-0,3 \mathrm{~cm}$, seríceo, lobos subulados; corola alvo-esverdeada, $1-1,5 \times 0,5-0,7 \mathrm{~cm}$, externamente serícea, internamente glabra. Bagas oblongo-ovóides, pedunculadas, 1,5-2× $0,5-1 \mathrm{~cm}$.

Esta espécie apresenta uma ampla distribuição geográfica, ocorrendo em florestas decíduas ou perenifólias do México, América Central, Colômbia, Venezuela, Guianas, Bolívia e Brasil (Taylor et al. 2004). Na Reserva Ducke foi coletada nas florestas de platô com flores em fevereiro. Campos \& Brito (1999: pág. 646).

8.II.1995 (fl) Vicentini et al. 855 (INPA KMONY SPF).

2.2 Amaioua guianensis Aubl., Hist. Pl. Gui. Franç., suppl. 13, t. 375. 1775.

Arvoretas até 5-6 m alt., $5 \mathrm{~cm}$ diâm. Tronco circular ou ligeiramente sulcado. Ritidoma marrom, estriado, escamoso; exterior da casca marrom, 1-2 mm de espessura, casca internamente creme ou marrom-avermelhada, ca. $1 \mathrm{~mm}$ de espessura; alburno bege, odor agradável. Estípulas caliptradas, lanceoladas, externamente seríceas, internamente glabras, 3-10 × 2-4 mm. Folhas opostas; pecíolo 5-12 mm compr., lâmina lanceolada, 9,5-18,5 ×3$6,5 \mathrm{~cm}$, ápice acuminado a aristado, base cuneada, face adaxial glabra, esparsamente pubescente com as nervuras tomentosas na face abaxial; nervuras laterais 8-16 pares. Inflorescências estaminadas fasciculadas ou corimbosas, multifloras, pedunculadas, $1,5-2 \mathrm{~cm}$ compr. Flores estaminadas pediceladas; cálice 2-4 × 4-5 mm, lobos subulados, densamente seríceos; corola 6-lobada, $1,2-1,5 \mathrm{~cm}$ compr., serícea. Inflorescências pistiladas capitadas ou densamente fasciculadas, multifloras, sésseis. Flores pistiladas sésseis; cálice 6lobado, 5-7,5 × 2,5-3 mm, subulados, densamente seríceos; corola 6-mera, 1-2×0,4$0,5 \mathrm{~mm}$. Bagas vermelhas a arroxeadas, oblongas, sésseis, 9-15 × 8-12 mm; sementes $4-5,5 \times 3-5 \mathrm{~mm}$.

Apresenta ampla distribuição na região amazônica, ocorrendo nas Guianas, Venezuela, Bolívia, Peru e Brasil. Na Reserva Ducke foi coletada nas florestas de platô, baixio e campinarana, apenas com frutos, de fevereiro a maio (Campos \& Brito 1999: pág. 646). 27.IV.1988 (fr) Ramos 1879 (INPA K MO NY SPF); 26.II.1996 (fr) Campos \& Pereira 523 (INPA MO NY SPF);21.II.1996 (fr) Campos et al. 505 (INPAMONY); 14.II.1996 (fr) Campos et al. 490 (INPA K NY SPF); 21.V.1996 (fr) Sothers \& Silva 865 (INPAMO SPF).

\section{Botryarrhena Ducke}

Árvores hermafroditas. Ramos cilíndricos, às vezes com exsudado resinoso. Estípulas curtamente unidas ao redor do caule, persistentes, triangulares. Folhas opostas, decussadas, pecioladas. Inflorescências terminais, em racemos ou racemiformepaniculadas. Flores bissexuais; cálice curto, 5denteado ou truncado; corola hipocrateriforme, alva, tubo curto, densamente serícea na região da fauce, 5-lobada, prefloração contorta; estames 5 , inseridos na região da fauce da corola, anteras dorsifixas; ovário 2-locular, 2- ou 4-ovulado em cada lóculo, estigma 2-partido. Frutos bacáceos, globosos, coriáceos, de cor desconhecida; sementes numerosas, subglobosas, lisas. 
Este gênero compreende apenas duas espécies, ocorrendo na região amazônica da Venezuela, Peru, Colômbia e Brasil (Steyermark 1983; Taylor et al. 2004). As flores bissexuais, em racemo, ovário bilocular e bagas com poucas sementes caracterizam este gênero. É muito semelhante a Stachyarrhena, também de distribuição amazônica, porém este possui flores unissexuais, sendo que as flores estaminadas dispostas em racemos similares aos de Botryarrhena, enquanto que as flores pistiladas e os frutos são solitários.

3.1 Botryarrhena pendula Ducke, Notizbl. Bot. Gart. Berlin-Dahlem 11: 476. 1932.

Fig 1c

Árvores $10-25 \mathrm{~m}$ alt., $12-20 \mathrm{~cm}$ diâm. Tronco cilíndrico, base reta. Ritidoma marromescuro, fissurado; exterior da casca marrom com manchas alvas, ca. $4 \mathrm{~mm}$ de espessura; casca internamente avermelhada ou rosada, ca. $5 \mathrm{~mm}$ de espessura, fibrosa; alburno alvorosado; odor forte. Estípulas 2-3 × 3-4 mm. Folhas enegrecidas quando secas; pecíolo 2,5$3,5 \mathrm{~cm}$, canaliculado, glabro; lâmina oblongoelíptica, oblanceolada ou lanceolada, 15-22,5× $6,3-8,5 \mathrm{~cm}$, ápice longamente acuminado a obtuso, base cuneada, glabra em ambas as faces; nervuras laterais 15-17 pares, impressas na face abaxial, salientes na face abaxial. Inflorescências em racemos, 4-8,5 cm compr. Flores subsésseis ou com pedicelos até $3 \mathrm{~mm}$ compr.; cálice truncado, 1-2 $1 \mathrm{~mm}$, glabro; corola 5-8 × $3 \mathrm{~mm}$. Bagas 1,2-1,6 × 1,2-1,6 $\mathrm{cm}$; sementes $8-10 \times 6-8 \mathrm{~mm}$.

Esta espécie ocorre na região amazônica do Brasil, Peru, Colômbia e Venezuela. Na Reserva Ducke foi coletada na floresta de platô apenas com frutos, nos meses abril e dezembro (Campos \& Brito 1999: pág. 641). 12.XII.1968 (fr) Prance et al. 9032 (NY); 28.IV.1994 (fr) Vicentini et al. 511 (INPA K MO NY SPF).

Material adicional examinado: BRASIL. AMAZONAS: Manaus, Distrito Agropecuário,

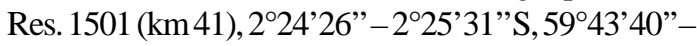
59 45'50"W, 50-125 m, 13.XI.1989 (fr) Campos \& Boom 29 (INPA K).

\section{Capirona Spruce}

Árvores freqüentemente de grande porte, hermafroditas. Tronco liso, com casca esfoliante. Ramos cilíndricos. Estípulas completamente fundidas em botão, dividindose em duas metades intrapeciolares, lanceoladas, conspíquas, decíduas. Folhas opostas, pecioladas, decussadas, bem desenvolvidas. Inflorescências terminais e nas axilas das folhas distais, em panículas geralmente 3-partidas. Flores bissexuais, vistosas; cálice subtruncado ou 5-lobado, em algumas flores com um dos lobos frequientemente expandido e petalóide, róseo ou avermelhado; corola campanulada ou infundibuliforme, alva ou rosada, com um anel de tricomas internamente, próximo à base, 5lobada, prefloração contorta; estames 5, inseridos na porção inferior do tubo da corola, anteras basifixas, inclusas; ovário 2-locular, óvulos muitos por lóculo, estigma 2-partido. Frutos capsulares, oblongos, cartáceos ou lenhosos, deiscência septicida; sementes numerosas, aplanadas, aladas.

Este gênero monotípico ocorre no Equador, Guianas, Venezuela, Bolívia e Brasil (Kirkbride 1985; Andersson \& Taylor 1994). As principais características que permitem a rápida identificação deste gênero são: tronco liso esfoliante, com ritidoma desprendendo-se em placas circulares, folhas bem desenvolvidas com estípulas intrapeciolares bem evidentes e flores com um dos lobos do cálice expandido e petalóide.

4.1 Capirona decorticans Spruce, J. Linn. Soc., Bot 3: 299. $1859 . \quad$ Fig 1d Capirona leiophloea Benoist, Bull. Mus. Hist. Nat. (Paris) 27: 367. 1921.

Árvores de 5-20 m alt., 10-35 cm diâm. Tronco circular, às vezes acanalado nas regiões mais superiores, base acanalada; raízes tabulares quando presentes pequenas. Ritidoma marrom a marrom-avermelhado, esfoliante, desprendendo-se em placas circulares, às vezes com lenticelas circulares em pequenas quantidades; exterior da casca verde, lisa, ca. $0,5 \mathrm{~mm}$ de espessura; casca internamente bege 
ou amarelada, 4-10 mm de espessura; alburno creme ou bege; exsudato em pequena quantidade, hialino, odor agradável. Ramos cilíndricos, glabros. Estípulas 1,5-2,5 × 0,8-1 cm, glabras ou esparsamente pilosas. Folhas pecioladas; pecíolo 1-3,5 cm compr., glabro ou esparsamente pubescente; lâmina lanceolada, elíptica a oval, $10-40 \times 5-25 \mathrm{~cm}$, ápice agudo a arredondado, base arredondada a acuminada, glabra a esparsamente pubescente; nervuras laterais $7-$ 10 pares, proeminentes em ambas as faces. Inflorescências 12-20 cm compr. Flores subsésseis ou com pedicelos até $5 \mathrm{~mm}$ compr.; cálice 3-7 mm compr., glabro ou externamente pubescente; lobo expandido rosado ou esverdeado, 3,5-12 × 1,5-4 cm; corola alva ou rosada, tubo $2,5-5 \mathrm{~cm}$ compr., fauce $2-3 \mathrm{~cm}$ diâm. Cápsulas obovóides, costadas, 2,5-3,5 $\times 0,1-0,13 \mathrm{~cm}$; sementes $5-8 \times 1-2 \mathrm{~mm}$.

Apresenta ampla distribuição, ocorrendo na Colômbia, Venezuela, Bolívia, Peru, Equador, Guianas e na Amazônia Brasileira, atingindo o norte do estado do Mato Grosso. Kirkbride (1985) na revisão do gênero reconheceu duas espécies, Capirona decorticans e C. leiophloea, diferenciadas pela presença e densidade de indumento nas folhas. Andersson \& Taylor (1994) consideraram C. leiophloea como um sinônimo de $C$. decorticans por observarem uma variação contínua no indumento. $\mathrm{O}$ tronco muito distinto, marrom a marrom-avermelhado, liso e desprendendo-se em placas permite a sua fácil identificação em campo mesmo em estado vegetativo. Na Reserva Ducke é uma espécie ocasional, a qual ocorre geralmente nas florestas de vertente ou baixio, sendo conhecida popularmente por "mulateiro" ou "pau-mulato", devido à distinta coloração do tronco. Coletada com frutos em junho de 1964, e não foi recoletada em estado fértil recentemente (Campos \& Brito 1999: pág. 645, 647).
5.VI.1964 (fr) Rodrigues \& Loureiro 5838 (INPA). Material adicional examinado: BRASIL. MATO GROSSO: Alta Floresta, Parque Estadual do Cristalino, 9³6'24"'S, 5555'40”'W, 252m, VIII.2006, Sasaki et al. 1378 (INPA K).

\section{Chimarrhis Jacq.}

Árvores hermafroditas, geralmente emergentes, freqüentemente com raízes tabulares. Ramos cilíndricos, às vezes com exsudado resinoso. Estípulas interpeciolares, triangulares, persistentes ou decíduas deixando um cicatriz circular acima do nó. Folhas opostas, sésseis ou pecioladas, decussadas. Inflorescências axilares, paniculadas a corimbosas. Flores bissexuais, protogínicas, odoríferas; cálice reduzido, truncado ou com (4-)5(-6) lobos reduzidos, em algumas flores de algumas espécies um dos lobos é expandido num calicofilo petalóide, alvo ou esverdeado; corola infundibuliforme a rotácea, alva ou esverdeada, internamente vilosa, lobos (4-)5 (-6), prefloração imbricada (difícil de observar, e dando aparência de valvar); estames 5, inseridos na parte distal do tubo da corola, filamentos vilosos, anteras dorsifixas, exsertas; ovário 2-locular, óvulos muitos por lóculo; estigma 2-partido. Frutos capsulares, globosos, elipsóides ou ovóides, pequenos, lenhosos, deiscência septicida; sementes numerosas, angulosas, com ala muito estreita.

Este gênero compreende cerca de 14 espécies distribuídas nas florestas tropicais da América Central, Caribe e América do Sul, sendo algumas endêmicas da Bacia Amazônica (Delprete 1999). As principais características que permitem a rápida identificação deste gênero são: tronco acanalado, estípulas interpeciolares e flores com um dos lobos do cálice expandido e petalóide.

\section{Chave para as espécies de Chimarrhis na Reserva Ducke}

1. Lâminas 5,5-14 × 4-7 cm; pecíolos 6-20 mm compr.; ramos do estigma 0,6-1 mm compr... 1. C. barbata

1'. Lâminas 8-32 × 7-18 cm; pecíolos $15-43 \mathrm{~mm}$ compr.; ramos do estigma $0,3-0,5 \mathrm{~mm}$ compr. 2. C. duckeana 
5.1 Chimarrhis barbata (Ducke) Bremek., Recueil Trav. Bot. Neerl. 31: 260. 1934.

Fig 1e

Árvores emergentes, 22-35 m alt., (25-) 40-45 cm diâm. Tronco acanalado, base acanalada ou com raízes tabulares pequenas. Ritidoma marrom-avermelhado ou marromacinzentado, fissurado; exterior da casca bege, estriada, ca. $15 \mathrm{~mm}$ de espessura, com desprendimento em placas papiráceas; casca internamente creme a amarelo-alaranjada, ca. $6 \mathrm{~mm}$ de espessura; alburno amarelo-alaranjado. Ramos glabros, cilíndricos, escamosos. Estípulas deltóides a estreito-triangulares, conatas, 4-5 $(-10) \times 4-5 \mathrm{~mm}$. Folhas pecioladas; pecíolo 2 $\times 0,6-0,8 \mathrm{~cm}$, glabro; lâmina elíptica, oval a obovada, 8-10(-17) ×4,5-7,5(-12) cm, ápice agudo a arredondado, base aguda, arredondada a obtusa; nervuras laterais 6-10 pares. Inflorescência 6-8 cm compr. Flores sésseis ou curtamente pediceladas; cálice reduzido, curtamente denteado, 0,5-1 × 2-3,5 mm; corola esverdeada a creme, barbelata, tubo 1-2 mm compr., 5-lobada, pubescente, de aparência lustrosa, 2-3,5 cm compr; anteras elípticas; estigma rosado. Cápsulas pubérulas, 7-10 × 4-6 mm; sementes 1-2 mm compr.

Esta espécie ocorre na amazônia brasileira, nos estados do Pará e Amazonas (Delprete 1996, 1999). Na Reserva ocorre na floresta de vertente. Floresce de setembro a outubro e frutifica em janeiro e fevereiro (Campos \& Brito 1999: pág. 626, 641).

26.IX.1995 (fl) Sothers et al. 568 (INPA K MO NY SPF); 12.X.1995 (fl) Sothers \& Pereira 625 (INPA K MO NY SPF); 9.II.1996 (fr) Campos et al. 468 (INPA MO NY SPF); 17.I.1996 (fr) Sothers et al. 750 (INPA K MO NY SPF); 14.VIII.1996 Assunção et al. 369 (INPA K MO SPF).

5.2 Chimarrhis duckeana Delprete, Fl. Neotropica 77: 179, fig. 79. 1999.

Árvores 20-25 m alt., 30-55 cm diâm. Ritidoma marrom claro, fissurado; casca internamente amarelo-alaranjada; odor suave. Ramos glabros, aplanados, acinzentados, com lenticelas lineares. Estípulas deltóides a estreitotriangulares, livres ou curto-conatas, $0,7-1,9 \times$ 0,7-1 cm, glabras. Folhas pecioladas; pecíolo
7-10 mm compr., glabro; lâmina largamente elíptica ou ovada, 8-32 ×7-18 cm, ápice obtuso a arredondado, base obtusa ou cordada; nervuras laterais 8-10 pares. Inflorescência $6,5-22 \mathrm{~cm}$ compr. Flores pediceladas; pedicelos 1-2 mm compr.; cálice reduzido, ca. 0,5 mm compr., ondulado; corola alva, barbelata, tubo 1-1,5 mm compr., 5-lobada, ca. 2,5 cm compr.; anteras ca. $1 \mathrm{~mm}$ compr. Cápsulas pubérulas, 6-12 × 4-6 mm; sementes 1-2 mm compr.

Esta espécie ocorre na região de Manaus (Delprete, 1999), onde floresce de dezembro a fevereiro e frutifica de julho a outubro. $\mathrm{Na}$ Reserva, foi coletada com flores em dezembro, na floresta de vertente (Campos \& Brito 1999: pág. 641).

12.XII.1995 (fl) Ribeiro \& Assunção 1776 (INPA MONY).

\section{Chomelia Jacq.}

Arbustos, arvoretas ou lianas hermafroditas. Ramos cilíndricos, às vezes com espinhos. Estípulas interpeciolares, triangulares, persistentes ou decíduas, geralmente seríceas na face adaxial. Folhas opostas, pecioladas, decussadas, com nervação terciária paralela. Inflorescências axilares, cimosas até subcapitadas. Flores bissexuais, geralmente distílicas; cálice 4-lobado; corola hipocrateriforme ou infundibuliforme, alva ou alvo-amarelada, tubo estreito, freqüentemente seríceo externamente, internamente usualmente glabro, 4-lobada, prefloração valvar; estames 4 , inseridos na região da fauce do tubo da corola, anteras dorsifixas, inclusas ou exsertas; ovário 2-locular, óvulos 1 por lóculo; estigma 2-partido. Frutos drupáceos, elipsóides ou oblongos, carnosos, roxos ou negros; pirênio solitário, 1-3-locular, liso ou costado; sementes cilíndricas.

Chomelia é neotropical e compreende ca. 50 espécies que ocorrem na América Central e do Sul (Taylor et al. 2004). Caracteriza-se por folhas com nervação terciária paralela, inflorescências axilares, corola longa, estreita e serícea e fruto drupáceo. Pode ser confundido com Guettarda (que não possui espinhos e cujas inflorescências são escorpióides) e Malanea (lianas sem espinhos e com flores menores). 


\section{Chave para as espécies de Chomelia na Reserva Ducke}

1. Folhas sem domácias, hirsutas em ambas as faces 1. C. estrellana

1'. Folhas com domácias, glabras na face adaxial, esparsamente pubescentes na face abaxial.

2. Plantas geralmente com espinhos; pecíolos $12-26 \mathrm{~mm}$ compr. 2. C. malaneoides

2'. Plantas geralmente inermes; pecíolos $4-8 \mathrm{~mm}$ compr. 3. C. tenuiflora

\subsection{Chomelia estrellana Müll. Arg., Flora 58:} 452. 1875 .

Fig. 1f

Árvores com ramos escandentes ou lianas lenhosas. Tronco circular, de base reta, com espinhos. Ritidoma marrom escuro, estriado, com lenticelas grandes, transversais, salientes; exterior da casca marrom escuro, fina, ca. $1 \mathrm{~mm}$ de espessura; casca internamente pálida com estrias marrons, fibrosa, ca. $1 \mathrm{~mm}$ de espessura; alburno creme. Ramos cilíndricos, com espinhos, escamosos, hirsutos a glabrescentes. Estípulas persistentes, $5-8 \mathrm{~mm} \times 2-3 \mathrm{~mm}$, hirsutas. Folhas pecioladas; pecíolo hirsuto, $1-1,2 \mathrm{~cm}$ compr.; lâmina lanceolada, ovada ou elíptica, 9,5$12,7 \times 4,5-5,8 \mathrm{~cm}$, ápice acuminado, base aguda a obtusa, hirsuta em ambas as faces, principalmente nas nervuras; nervuras laterais 5-7 pares, impressas na face adaxial, sem domácias. Inflorescências capitadas, 2-3floras, pedunculadas, pendentes, pedúnculo 6-8,5 cm compr, hirsuto. Flores sésseis; hipanto lanoso; cálice com lobos longamente subulados, 1-1,5 × 0,15-0,2 cm, hirsutos; corola hipocrateriforme, creme a alva ou alvo-esverdeada, externamente hirsuta ou estrigosa, 2,5-3 $30,2-0,3 \mathrm{~cm}$, lobos ca. $5 \mathrm{~mm}$ compr. Drupas elipsóides, 1,5-2 $2 \times 0,5-0,8 \mathrm{~cm}$, hirsutas, violáceas; pirênio 1 , levemente costado.

Espécie registrada na Guiana Francesa, e no Brasil no estado do Amazonas. Na Reserva Ducke ocorre nas florestas de baixio, vertente e platô. Floresce em outubro e frutifica nos meses de janeiro a maio (Campos \& Brito 1999: pág. 262, 643).

30.X.1996 (fl) Assunção 420 (INPA K MO NY SPF); 22.III.1996 (fr) Campos et al. 575 (INPA K MO NY, SPF); 19.I.1996 (fr) Costa \& Silva 723 (INPA K MO NY SPF); 4.V.1994 (fr) Ribeiro et al. 1304 (INPA K MONY SPF).
6.2 Chomelia malaneoides Müll. Arg., Flora 58: 452.1875.

Lianas lenhosas ou arvoretas com ramos escandentes. Tronco cilíndrico, base reta. Ritidoma marrom-avermelhado, rígido, rugoso, de desprendimento pulverulento, com lenticelas salientes, esbranquiçadas, elípticas a circulares; exterior da casca marrom escura, fina, ca. $0,5 \mathrm{~mm}$ de espessura; casca internamente amarelada, fibrosa. Ramos cilíndricos, com espinhos, glabros, fistulosos ou não. Estípulas decíduas, 3-4×2$3 \mathrm{~mm}$, pubérulas externamente, seríceas internamente. Folhas pecioladas; pecíolo 1,22,6 cm compr., pubérulo; lâmina elíptica a lanceolada ou obovada, $13-18 \times 5-8,5 \mathrm{~cm}$, ápice agudo, base cuneada a atenuada, face abaxial glabra, exceto a nervura central esparsamente pubérula, face adaxial esparsamente pubérula com as nervuras pubescentes; nervuras laterais 6-7 pares, com domácias. Inflorescências em dicásios subcapitados até ramificados, multifloras, pilosas, pedunculadas, $10-12 \mathrm{~cm}$ compr. Flores sésseis; hipanto sedoso-seríceo a lanoso; cálice com lobos triangulares, 3-4×1-1,5 mm, seríceo; corola hipocrateriforme, alva, externamente serícea, tubo 3-3,5×0,2-0,3 cm, lobos 4-5 mm compr. Drupas oblongas, ligeiramente comprimidas, $3-3,5 \times 1,5-2 \mathrm{~cm}$, pubérulas, negras a violáceas; pirênio 1 , levemente costado.

Esta espécie ocorre na Venezuela, Guianas, Equador, Peru, Bolívia e Brasil. No Brasil ocorre nos estados do Amazonas, Mato Grosso e Pará. Alguns indivíduos desta espécie na Reserva possuem inflorescências ramificadas desenvolvidas, ao invés das inflorescências subcapitadas mais comumente encontradas em outras localidades. $\mathrm{Na}$ Reserva Ducke foi coletada apenas nas florestas de baixio. Floresce no mês de novembro e frutifica no mês de março (Campos \&Brito 1999: pág. 626, 643). 
24.III.1995 (fr) Brito et al. 4 (INPA K MO NY SPF); 3.XI.1994 (fl) Ribeiro et al. 1482 (INPA K MO NY SPF).

6.3 Chomelia tenuiflora Benth., J. Bot. (Hooker) 3: 235. 1841.

Arvoretas 3-4 m alt., 5-9 cm diâm. Tronco circular, às vezes levemente acanalado, base reta ou acanalada, raramente com raízes tabulares. Ritidoma marrom escuro, com lenticelas em pequena quantidade, elípticas, transversais; exterior da casca marrom-escura ou marrom-acinzentada, ca. $0,5 \mathrm{~mm}$ de espessura; casca internamente alaranjada a avermelhada, ca. $3 \mathrm{~mm}$ de espessura, alburno amarelo ou marrom. Ramos cilíndricos, inermes, pubescentes a glabrescentes. Estípulas decíduas, 2-4×1-2 mm, tomentosas ou seríceas. Folhas pecioladas; pecíolo 4 $8 \mathrm{~mm}$ compr., pubescente; lâmina lanceolada ou elíptica, 7,2-10 × 3-5,2 cm, ápice acuminado, base aguda, face adaxial glabra exceto as nervuras estrigosas, face abaxial esparsamente pubescente com as nervuras estrigosas; nervuras laterais 5-7 pares, com domácias. Inflorescências 2-3-floras, fasciculadas a subcapitadas, curtopedunculadas, 4-11 mm compr. Flores sésseis; hipanto seríceo; cálice com lobos subulados, $2-4 \times 2-4 \mathrm{~mm}$, seríceos; corola hipocrateriforme, alva, externamente serícea, tubo $1,5-2,5 \times 0,1-0,2 \mathrm{~mm}$, lobos 5-6 mm compr. Drupas elipsóides, 1,1-1,6 × 0,3$0,4 \mathrm{~cm}$, tomentosas a glabrescentes, negras.

Ocorre nas florestas tropicais do México ao Brasil e Bolívia. Os espécimes coletados na Reserva não apresentam espinhos, apesar desta espécie ser frequentemente armada em outras localidades. Na Reserva Ducke é frequiente no subosque das florestas de platô; foi coletada com flores em setembro e com frutos de fevereiro a abril (Campos \& Brito 1999: pág. 643).

5.IV.1994 (fr) Vicentini et al. 476 (INPA, K, MO, NY); $10 . I I .1996$ (fr) Campos et al. 476 (INPA, MO, NY SPF); 4.IX.1996 (fl) Campos \& Assunção 608 (INPA K MO NY SPF); 5.XI.1996 (est) Ribeiro \& Pereira 1848 (INPA K MO SPF).
7. Cordiera A. Rich.

Árvores, arvoretas ou arbustos, dióicos. Ramos cilíndricos, às vezes com exsudado resinoso. Estípulas interpeciolares ou às vezes unidas ao redor do caule, persistentes, ovadas ou triangulares. Folhas opostas, pecioladas, decussadas. Inflorescências estaminadas terminais, cimosas, fasciculadas ou capitadas. Flores estaminadas com cálice truncado ou 4-5(7)-denticulado; corola hipocrateriforme, alva ou alvo-esverdeada, externamente serícea, internamente glabra, tubo às vezes com constricção no ápice, lobos (3)4-5(-7), prefloração contorta; estames (3)4-5(-7), inseridos na porção mediana ou distal do tubo da corola, anteras dorsifixas; pistilódio semelhante ao estigma; ovário estéril. Inflorescências pistiladas terminais, com flores poucas ou solitárias. Flores pistiladas com cálice e corola semelhantes aos das flores estaminadas, freqüentemente de tamanho menor e com um lobo a mais; estaminódios semelhantes aos estames; ovário 2-3(-5)locular, óvulos 3 a muitos por lóculo, estigma 2-3(-5)-partido. Frutos bacáceos, globosos, carnosos, geralmente negros; sementes geralmente numerosas, comprimidas, envolvidas numa polpa gelatinosa.

Compreende ca. 24 espécies distribuídas na América Central e do Sul (Taylor et al. 2004), antes incluídas dentro de Alibertia, com o qual apresentam bastante afinidade.

7.1 Cordiera myrciifolia (Spruce ex K. Schum.) C. Persson \& Delprete, Fl. Venez. Guayana 8: 559. 2004.

Fig 19 Alibertia myrciifolia Spruce ex K. Schum., Fl. bras. 6(6): 393. 1889.

Arvoretas ou arvoretas, 4-6 $\mathrm{m}$ alt. Tronco acanalado, base acanalada. Ritidoma marromclaro; exterior da casca marrom-clara, ca. $1 \mathrm{~mm}$ de espessura; casca internamente bege, fibrosa; alburno marrom. Ramos cilíndricos, glabros. Estípulas truncadas ou largamente triangulares, 3-4 $\times 2-3 \mathrm{~mm}$, glabras. Folhas pecioladas; pecíolo glabro, 7-11 mm compr.; lâmina elíptica, 6,5-12 × 0,2-0,4 cm, ápice acuminado, base atenuada, glabra; nervuras laterais 8-10 pares. 
Inflorescências estaminadas fasciculadas, 4-8-floras, subsésseis. Flores estaminadas sésseis; cálice truncado, glabro, ca. $1 \times 1 \mathrm{~mm}$; corola alva, 13-15 mm compr., 4-lobada; estames 4. Flores pistiladas não vistas. Bagas globosas, 10-12 × 10-12 mm, glabras. Ocorre no Panamá, Venezuela, Colômbia, Guianas, Bolívia e Brasil (Taylor et al. 2004). No Brasil apresenta uma ampla distribuição ocorrendo nos estados do Amazonas, Rondônia, Roraima, Amapá, Maranhão, Ceará, Mato Grosso e Minas Gerais. Na Reserva Ducke foi coletada em floreta de baixio e floresta de platô, apenas com flores estaminadas, em setembro. 20.IX.1995 (fl) Assunção \& Costa 242 (INPA K MO NY SPF); 22.III.1996 (est) Costa \& Pereira 770 (INPAMO).

\section{Cosmibuena Aubl.}

Arbustos ou árvores hermafroditas, geralmente suculentos, às vezes epifíticos. Ramos cilíndricos. Estípulas parcialmente unidas ao redor do caule, oblanceoladas ou obovadas, decíduas. Folhas opostas, decussadas, suculentas, pecioladas. Inflorescências terminais, brevemente cimosas. Flores bissexuais, homostilas, noturnas; cálice truncado ou 5-6-denteado; corola hipocrateriforme, alva, passando a amarela quando velha, glabra, 5-6-lobada, prefloração imbricada; estames 5-6, inseridos na porção superior do tubo da corola, anteras basifixas; ovário 2-locular, óvulos muitos por lóculo; estigma 1-partido. Frutos capsulares, cilíndricos ou oblongos, lenhosos, deiscência septicida; sementes numerosas, comprimidas, aladas.

Cosmibuena apresenta quatro espécies e ocorre do México à Bolívia (Taylor 1992). As principais características que permitem a rápida identificação deste gênero são: ramos e folhas suculentos, estípulas interpeciolares, grandes e decíduas, poucas flores grandes com a corola alva e os frutos capsulares com sementes pequenas e aladas. Hillia é semelhante, porém esse possui flores solitárias e sementes com tufo de tricomas.
8.1 Cosmibuena grandiflora (Ruiz \& Pav.) Rusby, Bull. New York Bot. Gard. 4: 368. 1907.

Fig $1 \mathrm{~h}$

Arbustos suculentos até $3 \mathrm{~m}$ alt., terrestres ou epifíticos. Estípulas obovadas ou elípticas, 8-30 mm compr. Folhas pecioladas; pecíolo 0,5-4 cm compr.; lâmina elíptica, 6,5$19 \times 3,5-16 \mathrm{~cm}$, ápice agudo, base cuneada ou aguda, cartácea, glabra; nervuras laterais 4-6 pares. Inflorescências cimosas, 3-5flora em 1-2 grupos, ebracteadas; pedúnculo 6-30 mm compr.; pedicelos $0,5-3 \mathrm{~cm}$ compr. Flores aromáticas; cálice $0,4-1,5 \mathrm{~cm}$ compr., glabro, brevemente denteado; corola alva, passando a amarela quando velha, tubo 6-9 cm compr., lobos elíptico-oblongos, 1,5-3,5 cm compr. Cápsulas oblongos ou elipsóides, 4 $6,5 \times 0,6-1,3 \mathrm{~cm}$; sementes 5-6×1-2 mm.

Ocorre esporadicamente nas florestas úmidas tropicais, do sul da Nicarágua até a Bolívia. Provavelmente trata-se do táxon tratado por Campos \& Brito (1999: pág. 631) como "Hillia sp. 1". Na Reserva Ducke foi encontrada com flores em abril.

9.IV.1962 (fl), Rodrigues et al. 3581 (INPA).

Material adicional examinado: BRASIL. RORAIMA: Serra Tepequem, 1500 m, 16.II.1967 (fr) Prance et al. 4413 (INPA K NY).

\section{Coussarea Aubl.}

Arbustos ou arvoretas hermafroditas. Ramos quadrangulares quando jovens, tornando-se cilíndricos, às vezes com exsudado resinoso. Estípulas interpeciolares ou às vezes unidas ao redor do caule, triangulares a largamente triangulares, persistentes ou decíduas deixando um cicatriz circular acima do nó. Folhas opostas ou raramente ternadas, pecioladas ou sésseis, decussadas. Inflorescências terminais ou às vezes axilares, paniculadas, tirsóides, racemiformes ou umbeliformes. Flores bissexuais, geralmente noturnas, às vezes distílicas; cálice truncado ou 4-5-denteado; corola hipocrateriforme a tubulosa, alva, glabra no interior, 4-lobada, prefloração valvar; estames 4 , inseridos na região mediana ou superior do tubo da corola, anteras dorsifixas; 
ovário incompletamente 1-locular, óvulos 1(-2); estigma inteiro ou bífido. Frutos drupáceos, elipsóides ou globosos, carnosos ou espongosos, alvos ou amarelos, geralmente com 1 semente grande.

Este gênero neotropical ocorre no México, América Central e do Sul e compreende cerca de 100 espécies (Taylor et al. 2004). Coussarea é reconhecível pelos frutos alvos ou amarelos unisseminados, folhas decussadas, flores alvas e estípulas triangulares, mas nunca aristadas. Pode ser confundido com Faramea, Psychotria ou Rudgea. Uma terceira espécie de Coussarea foi citada por Campos \& Brito (1999: pág. 642) como "Coussarea aff. grandis", porém infelizmente não foi possível tratá-la aqui pois o material não foi revisado pela primeira autora e as informações disponíveis sobre tal espécime não eram adequadas para efetuar uma determinação confiável.

\section{Chave para as espécies de Coussarea na Reserva Ducke}

1. Folhas $21-29 \times 8,5-13 \mathrm{~cm}$, enegrecidas quando secas; estípulas 6-8 mm compr. ..... 1. C. ampla

1'. Folhas 7-10 × $-5 \mathrm{~cm}$, verdes ou verde-acinzentas quando secas; estípulas 1-3 mm compr.....

2. Coussarea sp.

9.1 Coussarea ampla Müll. Arg., Flora $58: 466.1875$.

Fig 1i

Arvoretas 6-7 $\mathrm{m}$ alt., 7,5-12 cm de diâm. Tronco circular, base reta. Ritidoma marrom, estriado, às vezes reticulado; exterior da casca marrom, ca. $1 \mathrm{~mm}$ de espessura; casca internamente marrom-clara, ca. $8 \mathrm{~mm}$ de espessura; alburno bege, fibroso. Ramos quadrangulares a aplanados, glabros. Estípulas unidas ao redor do caule, deltóides, $6-8 \times 7-$ $9 \mathrm{~mm}$, glabras, persistentes ou decíduas. Folhas opostas, pecioladas, enegrecidas quando secas; pecíolo 1,5-3 cm compr., glabro a esparsamente pubérulo; lâmina oblonga ou elíptica, $21-29 \times 8,5-13 \mathrm{~cm}$, ápice acuminado, base aguda a obtusa, glabra na face adaxial, esparsamente pubérula na face abaxial; nervuras laterais 8-9 pares. Inflorescências terminais, paniculadas, ca. $6 \mathrm{~cm}$ compr., pedunculadas. Flores subsésseis ou curtopediceladas; cálice 1-1,5 mm compr., pubérulo; corola tubulosa, alva, glabra externamente, tubo ca. 2,7 cm compr., ca. $1 \mathrm{~mm}$ diâm., lobos ca. 5 $\mathrm{mm}$ compr. Drupas oblongas a globosas, 2 2,6 $\times 1,5-2 \mathrm{~cm}$, lisas; semente oblonga a cilíndrica, $1,5-1,7 \times 1-1,3 \mathrm{~cm}$.

Esta espécie só foi registrada até o momento no Brasil. Na Reserva Ducke só foi coletada na floresta de platô, florescendo em maio e com frutos em março e julho (Campos \& Brito 1999: pág. 626, 640).
19.III.1996 (fr) Campos \& Silva 538 (INPA K MG MO NY SPF); 2.VII.1997 (fr) Assunção et al. 534 (IAN INPA MO); 15.V.1997 (fl) Martins \& Pereira 04 (INPA K).

\subsection{Coussarea sp.}

Arbustos ou arvoretas até $2,5 \mathrm{~m}$ alt. Ramos cilíndricos, glabros. Estípulas unidas ao redor do caule, $1-3 \times 1-2 \mathrm{~mm}$, glabras, decíduas. Folhas opostas, pecioladas; pecíolo 9-12 mm compr., glabro; lâmina elíptica, 7$10 \times 2-5 \mathrm{~cm}$, ápice acuminado, base agudo ou atenuada, glabra em ambas as faces; nervuras laterais 5-7 pares, com domácias pilosas nas axilas abaxiais. Inflorescências terminais, pedunculadas, subcapitadas ou congestocimosas, 3-4,2 cm compr. Flores subsésseis ou curto-pediceladas; cálice ca. 1,5 mm compr., esparsamente pubérulo, truncado; corola não vista. Drupas jovens oblongas, $12-$ $15 \times 0,7-0,9 \mathrm{~mm}$, glabras.

Este táxon foi determinado erroneamente como $C$. revoluta Steyerm. em herbários e no guia de identificação da Reserva (Campos \& Brito 1999: pág. 642). O único espécime coletado na Reserva apresenta futos imaturos e não foi possível confirmar sua identidade. De modo geral este espécime assemelha-se a C. violacea Aubl. e C. granvillei Delprete \& B.M. Boom, no entanto diferindo das mesmas devido à presença de domácias pilosas na 
superfície abaxial da folha. Na Reserva Ducke foi coletada apenas uma vez na floresta de platô, com frutos em fevereiro.

8.II.1996 (fr) Campos et al. 464 (INPA MO NY SPF).

\section{Duroia L.f.}

Árvores, arvoretas ou arbustos, dióicos, freqüentemente com formigas nos ramos ou folhas. Ramos quadrangulares ou cilíndricos, freqüentemente fistulosos, glabros ou pilosos. Estípulas unidas num capuz cônico sobre a gema terminal, decíduas, seríceas ou pilosas. Folhas opostas ou 2-5-verticiladas, decussadas, sésseis ou pecioladas, às vezes dotadas de protuberâncias basais cuja presença está associada com a presença de formigas. Inflorescências estaminadas terminais, cimosas, fasciculadas ou capitadas. Flores estaminadas com cálice truncado ou 5-8-lobado; corola hipocrateriforme, alva a amarelada, geralmente carnosa, serícea externamente, glabra a pilosa internamente, 58-lobada, prefloração contorta; estames 5-8, inseridos no tubo da corola, anteras dorsifixas; pistilódio semelhante ao estigma, ovário estéril. Inflorescências pistiladas 1-3-floras, capitadas. Flores pistiladas com cálice e corola semelhantes ao das flores estaminadas ou freqüentemente de tamanho maior; estaminódios semelhantes aos estames; ovário 1-locular, óvulos muitos por lóculo; estigma inteiro. Frutos bacáceos, bem desenvolvidos, ovóides ou oblongos, coriáceos ou lenhosos, geralmente pardos; sementes numerosas, comprimidas ou suborbiculares, envolvidas numa polpa gelatinosa.

Este gênero apresenta cerca de 30 espécies neotropicais, uma no Costa Rica e as demais na América do Sul (Taylor et al. 2004). Este gênero é semelhante à Amaioua, porém as flores pistiladas e os frutos solitários caracterizam Duroia.

\section{Chave para as espécies de Duroia na Reserva Ducke}

1. Folhas opostas

1. D. gransabanensis

1'. Folhas ternadas.

2. Folhas sésseis, com um par de domácias em forma de bolsa na base ..... 4. D. saccifera

2'. Folhas pecioladas, sem domácias conspícuas base.

3. Folhas lanceoladas a elípticas ou obovadas, cartáceas, $25-30 \times 8-11 \mathrm{~cm}$; pecíolo $1,5-2 \mathrm{~cm}$ compr.

2. D. longiflora

3'. Folhas ovadas a lanceoladas, coriáceas, 30-40×14-24 cm; pecíolo 5-8,5 cm compr. 3. D. macrophylla

10.1 Duroia gransabanensis Steyerm., Mem. New York Bot. Gard. 12(3): 205. 1965.

Árvores até $18 \mathrm{~m}$ alt., $15-22 \mathrm{~cm}$ de diâm. Tronco circular, base reta. Ritidoma marrom-avermelhado, finamente estriado, duro; exterior da casca marrom, fina, ca. 0,5 $\mathrm{mm}$ de espessura; casca internamente bege, fibrosa, ca. $2 \mathrm{~mm}$ de espessura; alburno creme. Ramos fistulosos ou não, escamosos, glabros. Estípulas seríceas, $10-15 \mathrm{~mm}$ compr. Folhas opostas, pecioladas; pecíolo 1,2-2 cm compr., pubérulo; lâmina obovada a lanceolada, $24-30 \times 13-18 \mathrm{~cm}$, coriácea, glabra ou as nervuras esparsamente pubérulas na face abaxial, ápice agudo a obtuso, base cuneada, margem revoluta; nervuras laterais 9-13 pares, impressas na face abaxial. Inflorescências estaminadas fasciculadas ou curto-pedunculadas. Flores estaminadas pediceladas, pedicelos $0,2-1,3 \mathrm{~cm}$ compr.; cálice 6-7 ×5,5-6 mm, truncado; corola creme, $1-1,5 \times 0,5 \mathrm{~cm}$. Inflorescências e flores pistiladas não vistas. Bagas solitárias, sésseis, elipsóides a globosas, 3,3-4,5 ×3,1$3,8 \mathrm{~cm}$, pubérulas.

Ocorre em florestas de galeria na região da Grande Savana Venezolana, sendo este o primeiro registro para o Brasil. É facilmente reconhecível pelas folhas opostas, bem desenvolvidas, coriáceas e glabras e as estípulas 
caliptradas e decíduas. Nos ramos fistulosos habitam pequenas formigas marrons, inofensivas que também fazem ninhos sobre os ramos e as folhas. Na Reserva Ducke foi coletada na floresta de platô apenas com frutos, nos meses de abril e maio (Campos \& Brito 1999: pág. 626, 646).

1.IV.1996 (fr) Campos \& Silva 591 (INPAKMGMONY SPF); 12.V.1964(fr) Rodrigues \& Loureiro 5813 (INPA).

10.2 Duroia longiflora Ducke, Arch. Jard. Bot. Rio de Janeiro 4: 181. 1925.

Árvores até $17 \mathrm{~m}$ alt., ca. $15 \mathrm{~cm}$ diâm. Tronco circular, base acanalada, com pequenas raízes tabulares de até $50 \mathrm{~cm}$ alt. Ritidoma marrom escuro, estriado a fissurado; exterior da casca marrom com estrias creme, fibrosa, ca. $2 \mathrm{~mm}$ de espessura; alburno creme-rosado. Ramos ligeiramente quadrangulares, glabros. Folhas ternadas, pecioladas; pecíolo 1,5-2 cm compr.; lâmina lanceolada a elíptica ou obovada, 25-30×8-11 cm, ápice curto-acuminado, base cuneada, margem revoluta, glabra em ambas as faces a esparsamente pubescente na face abaxial; nervuras laterais ca. 12 pares, impressas na face adaxial. Inflorescências estaminadas cimosas. Flores estaminadas com cálice ca. $3 \mathrm{~mm}$ compr.; corola $3.5-4 \mathrm{~cm}$ compr., tubo alvo, lobos esverdeados. Flores pistiladas não vistas. Bagas solitárias, subglobosas a obovóides, ca. 5,5 ×4,5 cm.

Ocorre nas Guianas e Amazônia Central. Na Reserva Ducke foi encontrada apenas em estado estéril, sendo que o nome aplica-se provisoriamente. Seus registros no interior da Reserva baseiam-se na determinação dos materiais de espécimes numerados como \#3635, \#3678, e \#3679. A presente descrição baseia-se no trabalho de Boom \& Delprete (2002). Na Reserva, foi encontrada na floresta de platô e floresta de vertente (Campos \& Brito 1999: pág. 633).

10.3 Duroia macrophylla Huber, Bull. Soc. Bot. Geneve 6: 205. 1914.

Árvores 15-20 m alt., 12-25 cm diâm. Tronco circular, base às vezes acanalada, digitada. Ritidoma marrom a marrom- avermelhado, levemente fissurado, escamoso; exterior da casca marrom ou bege, fibrosa, 2$3 \mathrm{~mm}$ de espessura; casca internamente marrom, alaranjada ou rosada, 3-5 $\mathrm{mm}$ de espessura; alburno bege ou alvo-alaranjado; odor forte. Ramos quadrangulares, espessos, fistulosos, ferrugíneo-hirsutos. Estípulas 3-4× $1,5 \mathrm{~cm}$, ferrugíneo-tomentosas. Folhas ternadas, longamente pecioladas; pecíolo 58,5 cm compr.; lâmina ovada a lanceolada, 30$40 \times 14-24 \mathrm{~cm}$, coriácea, ápice acuminado, base obtusa, face adaxial glabra exceto as nervuras seríceas, face abaxial pubérula com as nervuras tomentosas; nervuras laterais (16-) 18-21 pares, impressas na face adaxial. Inflorescências estaminadas umbeladas, multifloras, 4,5-5,5 cm compr. Flores estaminadas pediceladas, pedicelos $0,5-3 \mathrm{~cm}$ compr.; cálice truncado ou 6-denticulado, ca. 1,5 cm compr., seríceo; corola creme, 3,3-4 cm compr., serícea, 6-lobada. Flores pistiladas não vistas. Bagas solitárias, sésseis, subglobosas ou elipsóides, 5,5-7,6×7-7,6 cm, ferrugíneo-tomentosas; sementes orbiculares, comprimidas, pubescentes, ca. $6 \times 7 \mathrm{~mm}$.

Esta espécie ocorre nas Guianas e no Brasil, nos estados do Pará, Amapá, Rondônia e Amazonas. Na Reserva Ducke ocorre nas florestas de baixio, vertente e platô; floresce em novembro e dezembro e frutifica de janeiro a junho (Campos \& Brito 1999: pág. 626, 633). 26.I.1995 (fr) Vicentini et al. 807 (INPAMO NY SPF); 3.VI.1995 (fr) Ribeiro et al. 811 (INPA MO NY); 10.XI.1995 (fl) Costa 29 (INPA K MO NY SPF), 24.X.1988(fl)Assunção419(INPAMONY); 6.XII.1994 (fl) Vicentini \& Pereira 775 (INPA K MO NY SPF); 24.IV.1995 (fr) Vicentini et al. 938 (INPA MO NY SPF); 14.XII.1966, Prance et al. 3645 (INPA K NY).

10.4 Duroia saccifera (Roem. \& Schult.) K. Schum., Fl. bras. 6(6): 362. $1889 . \quad$ Fig 1j

Árvores 8-10 m alt., 5-9 cm diâm. Tronco circular, base reta ou acanalada. Ritidoma marrom, estriado, escamoso; exterior da casca marrom, 1-2 $\mathrm{mm}$ de espessura; casca internamente marrom com estrias bege, ca. $2 \mathrm{~mm}$ de espessura; alburno esbranquiçado. Ramos quadrangulares ou 
cilíndricos, hirsutos, escamosos. Estípulas 1$3 \mathrm{~cm}$ compr., externamente hirsutas. Folhas ternadas, sésseis; lâmina lanceolada, oblanceolada a obovada, 20-40 ×9-18 cm, hirsuta, ápice agudo, base aguda com um par de domácias sacciformes, 8-15 mm compr.; nervuras laterais 18-19 pares. Inflorescências estaminadas cimosas ou umbeladas, 10-12-floras, 3-3,5 cm compr. Flores estaminadas pediceladas; pedicelos 5-10 mm compr.; cálice $1-2 \times 0,5-0,8 \mathrm{~cm}$, externamente hirsuto, curtamente 5-7-lobado; corola creme, 1,9-3 cm compr., esparsamente pilosa. Flores pistiladas solitárias, sésseis ; cálice 1,4-1,7 × 1-1,2 cm, pubescente, 6-9denteado; corola 2-3 × 1-1,5 cm, 6-lobada. Bagas subglobosas ou elipsóides, ligeiramente costadas, 6,5-7,6 × 3,5-4 cm, hirsutas.

Ocorre na Venezuela, Colômbia, Peru e Brasil, nos estados do Amazonas, Pará, Roraima e Acre. É facilmente reconhecível mesmo em estado vegetativo pelo par de domácias conspícuas na base das folhas, habitadas por formigas muito pequenas, vermelhas e agressivas (Azteca sp.), além das folhas sésseis, ternadas e hirsutas. $\mathrm{Na}$ Reserva ocorre em florestas de platô, campinarana e até mesmo em capoeiras; foi coletada com botões jovens em outubro, em flor em novembro, e frutifica de dezembro a março (Campos \& Brito 1999: pág. 626, 633, 647). 8.XII.1994 (fr) Sothers et al. 290 (INPA K MO SPF); 22.III.1994 (fr) Vicentini et al. 431 (INPA K MO SPF); 13.II.1996 (fr) Campos et al. 486 (INPAMO); 5.III.1991 (fr) Mota \& Coelho 59 (INPA MO); 29.X.1997 (fl) Ribeiro et al. 1926 (INPA K);
10.XI.1966 (fl) Prance et al. 3049 (INPA K NY); 20.III.1967 (fr) Prance et al. 4689 (INPA K NY); 8.II.2000 (fr) Anunciação \& Pereira 794 (SP SPF).

\section{Faramea Aubl.}

Arbustos ou arvoretas hermafroditas. Ramos geralmente aplanados. Estípulas interpeciolares ou às vezes unidas ao redor do caule ou num capuz cônico sobre a gema terminal, triangulares, geralmente aristadas, persistentes ou decíduas. Folhas opostas, pecioladas ou sésseis, geralmente dísticas, às vezes com as nervuras submarginais bem desenvolvidas. Inflorescências terminais e/ ou às vezes axilares, paniculadas, tirsóides, racemiformes ou umbeliformes. Flores bissexuais, às vezes distílicas; cálice truncado ou 4-denteado; corola hipocrateriforme a tubular, alva ou azul, glabra no interior,4-lobada, prefloração valvar; estames 4 , inseridos na região mediana ou superior do tubo da corola, anteras dorsifixas; ovário 1-locular ou incompletamente 2-locular, óvulos 1(-2), estigma inteira ou 2-partido. Frutos drupáceos, elipsóides, globosos ou frequientemente oblatos a reniformes, carnosos, negros, atrovioláceos ou azuis, unisseminados.

Gênero com cerca de 150 espécies, ocorrendo no México, América Central, Caribe e América do Sul (Taylor et al. 2004). Suas características mais marcantes são os ramos freqüentemente aplanados, as estípulas freqüentemente de ápice longo-aristado, as folhas dísticas, as flores 4-meras e os frutos negros, atrovioláceos ou azuis, globosos a reniformes, unisseminados.

\section{Chave para as espécies de Faramea na reserva Ducke}

1. Estípulas triangulares ou deltóides, ápice não ou somente curtamente aristado ...... 4. F. torquata

1'. Estípulas triangulares, ápice marcadamente aristado.

2. Inflorescências terminais em umbelas

2. F. corymbosa

2'. Inflorescências terminais ou axilares, em cimeiras ou panículas.

3. Folhas com nervação secundária pouco evidente e terciária obscura .... 5. Faramea sp.

3'. Folhas com a nervação secundária e terciária bem evidentes.

4. Folhas $8-13 \times 2,8-4,5 \mathrm{~cm}$; flores e frutos pendentes, poucos, em cimeiras com pedicelos ou pedúnculos longos, 1-3 cm compr.

1. F. capillipes

4'. Folhas 15,5-21 × 5,4-9,2 cm; flores e frutos eretos, numerosos, em panículas com pedicelos curtos, 1-2,5(-3) mm compr.

3. F. platyneura 
11.1 Faramea capillipes Müll.Arg., Flora 58: 470. 1875.

Arvoretas 2-5 m alt., 2-3 cm diâm., glabras. Tronco circular, às vezes achatado, de base reta. Ritidoma marrom, liso ou finamente estriado, com anéis transversais no tronco; exterior da casca marrom-clara, $0,2-0,5 \mathrm{~mm}$ de espessura; casca internamente bege a amarelada, ca. $1 \mathrm{~mm}$ de espessura; alburno creme ou ligeiramente acinzentado, fibroso, de odor agradável. Ramos cilíndricos. Estípulas unidas ao redor do caule, estreitamente triangulares, aristadas, 5-7 × 3-4 $\mathrm{mm}$, geralmente persistentes. Folhas sésseis a curtopecioladas; pecíolo 0-4 mm compr.; lâmina oblanceolada a elíptica, $8-13 \times 2,8-4,5 \mathrm{~cm}$, ápice acuminado, base aguda ou decurrente; nervuras laterais 7-8 pares. Inflorescências terminais, cimosas ou umbeladas, ca. $5 \mathrm{~cm}$ compr. Flores odoríferas, pêndulas, pedicelos 1-3 cm compr.; cálice ca. $0,5 \mathrm{~mm}$ compr., curtamente denteado; corola amarela, 5-7 $\times 3$ $-5 \mathrm{~mm}$. Drupas globosas, pêndulas, $7-8 \times 7-8$ $\mathrm{mm}$; semente $2-3 \times 4 \mathrm{~mm}$.

Apresenta ampla distribuição pela região amazônica da América do Sul, ocorrendo na Venezuela, Equador, Brasil, Peru, Colômbia, Bolívia, Suriname e Guiana Francesa. No Brasil ocorre nos estados do Pará, Amazonas, Roraima, Rondônia e Mato Grosso. Na Reserva Ducke ocorre nas florestas de platô e vertente e nas áreas perturbadas como beira de estradas; floresce de setembro a outubro e frutifica de outubro a março. Campos \& Brito (1999: pág. 626, 644, 647). 5.III.1996, (fr) Campos \& Silva 529 (INPA K NY SPF); 7.X.1994 (fr) Sothers 225 (INPA K NY SPF); 5.I.1996 (fr) Assunção 277 (INPA K NY SPF); 19.III.1996 (fr) Campos et al. 558 (INPA K NY SPF); 17.X.1995 (fl fr) Souza \& Assunção 120 (INPA NY SPF); 9.IX.1995 (fl) Sothers \& Silva 679(INPA KNY SPF); 18.XII.1997 (fr) Souza \& Assunção 497 (INPA MO); 6.X.1966, Prance et al. 2603 (INPA K NY).

11.2 Faramea corymbosa Aubl., Hist. Pl. Guiane 1: 102, t. 40. 1775.

Árvores ca. $15 \mathrm{~m}$ alt., ca. $16 \mathrm{~cm}$ diâm., glabras. Tronco circular, de base levemente acanalada. Ritidoma cinza-escuro, rugoso, finamente estriado; exterior da casca fina; casca internamente amarelo-escura, ca. $3 \mathrm{~mm}$ de espessura; alburno amarelo, de cheiro desagradável. Ramos cilíndricos. Estípulas unidas ao redor do ramo, estreitamente triangulares, longamente aristadas, 4-6×2-4 mm, decíduas. Folhas sésseis a subsésseis; lâmina elíptica a oblanceolada, 6-12×2,5-5,2 cm, ápice acuminado, base decurrente; nervuras laterais 7-9 pares. Inflorescências terminais, umbeladas, $2,5-4 \mathrm{~cm}$ compr., com mais de um pedúnculo de $1-1,8 \mathrm{~cm}$ compr. Flores com pedicelos 3-6 mm compr.; cálice ca. 0,5 mm compr., curto-denteado; corola alva, ca. $5 \mathrm{~mm}$ compr. Drupas oblatas, achatadas horizontalmente, 4-6×5-7 mm.

Ocorre na Venezuela, Guiana Francesa e Brasil, nos estados do Amazonas, Acre, Amapá, Pará e Rondônia. Na Reserva Ducke foi coletada apenas na floresta de vertente; floresce em outubro e frutifica em novembro (Campos \& Brito 1999: pág. 644).

3.X1995 (fl) Costa \& Assunção 375 (INPA K MO NY SPF); $16 . X I .1994$ (fr) Nascimento et al. 650 (INPA MONY SPF); 9.IX.1997 (fl) Brito et al. 32 (INPAMO).

11.3 Faramea platyneura Müll. Arg., Flora 58: 470.1875.

Fig. 1k

Arbustos ou arvoretas 1-3 m alt., glabras. Ramos cilíndricos. Estípulas conatas ao redor do ramo, triangulares, longamente aristadas, 8-10 × 4-7 mm. Folhas pecioladas; pecíolo 0,8-1,2 cm compr.; lâmina elíptica a ovada, 15,5$21 \times 5,4-9,2 \mathrm{~cm}$, ápice acuminado a aristado, base atenuada a decurrente; nervuras laterais 10-12 pares. Inflorescências terminais, em panículas, 3-5 cm compr., azuladas; pedúnculo 1,5-3 cm compr. Flores pediceladas, pedicelos 1-2,5(-3) mm compr;; cálice ca. $0,5 \mathrm{~mm}$ compr., curtamente denteado; corola lilás a azul, 1-1,5 cm compr., tubo ca. 2 mm larg.; estigma alvo. Drupas oblatas, ligeiramente achatadas horizontalmente, 6-8 $\times 10 \mathrm{~mm}$; semente $3-4 \times 5-7 \mathrm{~mm}$.

Ocorre na amazônia brasileira nos estados do Pará e Amazonas. Faz parte do complexo "Faramea multifora Rich.". Steyermark (1967) e Taylor et al. (2004) enfatizam a grande variabilidade morfológica desta espécie. $\mathrm{Na}$ Reserva Ducke é muito freqüente no subosque da floresta de platô e em capoeira; floresce de 
fevereiro a abril e frutifica de abril a julho (Campos \& Brito 1999: pág. 626, 644).

7.VII.1994 (fr) Hopkins et al. 1440 (INPA NY SPF); 9.IV.1995 (fl fr) Costa et al. 187 (INPA NY); 13.II.1995 (fl) Sothers \& Nascimento 318 (INPA K NY SPF); 22.III.1994 (fl) Vicentini et al. 434 (INPA NY SPF); 9.II.1996 (fl) Campos et al. 473 (INPA NY); 22.III. 1994 (fl) Hopkins et al. 1402 (INPA NY); 7.VI.1988 (fr) Santos \& Lima 958 (INPANY); 8.VIII.1997 (fr) Assunção et al. 607 (INPA MO).

11.4 Faramea torquata Müll. Arg., Flora 58: 471. 1875 .

Arbustos ou arvoretas 3-6 m alt., 3-6 $\mathrm{cm}$ diâm., glabras. Tronco circular ou acanalado, de base reta ou acanalada. Ritidoma marrom, estriado, com anéis transversais distribuídos irregularmente. Ramos cilíndricos ou fracamente quadrangulares, glabros. Estípulas unidas ao redor do caule, triangulares ou deltóides, 5-7 ×3-6 mm, agudas ou curtoaristadas, decíduas. Folhas pecioladas; pecíolo 1-1,5 cm compr.; lâmina elíptica, oblonga ou raramente oval, 14-25 × 4-9 cm; ápice acuminado, base atenuada a obtusa; nervuras laterais (12-)14-16 pares, amareladas quando secas, impressas na face adaxial; nervação terciária proeminente $\mathrm{e}$ reticulada. Inflorescências terminais, paniculadas, tripartidas, 4,5-10 cm compr.; pedúnculo 1-3 $\mathrm{cm}$ compr. Flores pediceladas, pedicelos 1-2 mm compr.; cálice 2-3 3 2-3 $\mathrm{mm}$, truncado; corola creme-esverdeada ou alva, 1,6-2 cm compr., o tubo 3-4 mm larg. Drupas globosas, 5-10 $\times 4-7 \mathrm{~mm}$; semente globosa, lisa, 4-6 $\times 4-6 \mathrm{~mm}$.

Esta espécie ocorre na Venezuela, Equador, Peru, Bolívia, Colômbia e Brasil. Na Reserva Ducke apresenta uma grande variação morfológica com relação à forma e tamanho das folhas. Ocorre nas florestas de baixio, vertente e platô; floresce em outubro e frutifica de fevereiro a junho (Campos \& Brito 1999: pág. 626, 641).

8.II.1996 (fr) Campos et al. 459 (INPA MO NY); 15.II.1996 (fr) Campos et al. 499 (INPA K MO NY); 22.III.1996 (fr) Campos et al. 576 (INPA K MO NY SPF); 9.X.1995 (fl) Sothers \& Pereira 607 (INPA MO NY); 23.X.1995 (fl) Sothers \& Silva 635 (INPA
MO NY SPF); 9.VI.1994 (fr) Vicentini \& Assunção 571 (INPA K MO NY SPF); (fr) Vicentini \& Silva 1077 (INPA MO NY).

\subsection{Faramea sp.}

Arbustos ca. 1,5 m alt., glabros. Ramos cilíndricos. Estípulas interpeciolares ou curtamente unidas ao redor do caule, triangulares ou ovadas, aristadas, $3-5 \times 2-4$ $\mathrm{mm}$, persistentes. Folhas pecioladas; pecíolo 3-5 mm compr.; lâmina estreito-elíptica ou estreito-lanceolada, 6-11,5×1,3-2 cm, ápice agudo, base aguda ou decurrente; nervuras laterais 10-14 pares, pouco evidentes; nervação terciária obscura. Inflorescências e flores não vistas. Infrutescências terminais, paniculadas. Bagas globosas ou oblatas, azuladas, 7-10 $\times 8-10 \mathrm{~mm}$.

O material disponível não é suficiente para identificar o táxon até o nível de espécie. É possível que se trate de Faramea angustifolia Spruce ex Müll Arg. (Flora 58: 474, 1875), no caso desta espécie ser realmente distinta de $F$. multiflora A. Rich. s. str. (Taylor et al. 2004). O grupo de espécies que inclui Faramea multiflora é amplamente distribuído nos Neotrópicos; ver também comentários acima, sob Faramea platyneura, também parte desse complexo de espécies. $\mathrm{Na}$ Reserva, este exemplar foi coletado em floresta de vertente e floresta de campinarana; frutifica no mês de setembro.

c. 27.VI.1997 (fr) Sothers 1031, 1032, 1033 (INPA).

\section{Ferdinandusa Pohl.}

Árvores, arvoretas ou arbustos hermafroditas. Ramos quadrangulares ou cilíndricos. Estípulas interpeciolares, triangulares, torcidas, decíduas. Folhas opostas, pecioladas, decussadas. Inflorescências terminais ou na axila das folhas distais, cimosas. Flores bissexuais, homostílicas; cálice 4-5-denteado; corola alva ou avermelhada, hipocrateriforme ou infundibuliforme, glabra no interior, lobos 4 5 , emarginados até bífidos, prefloração contorta; estames 4-5, inseridos na porção mediana do tubo da corola, inclusos ou exsertos, anteras dorsifixas; ovário 2-locular, óvulos muitos por lóculo, estigma 
2-partido. Frutos capsulares, oblongos ou cilíndricos, lenhosos, deiscência septicida; sementes numerosas, achatadas, aladas.

Possui cerca de 26 espécies distribuídas no América Central e do Sul (Taylor et al. 2004). Suas principais características são as estípulas retorcidas e decíduas, as inflorescências cimosas terminais, as flores vistosas e o fruto capsular com numerosas sementes aladas. Confunde-se freqüentemente com Ladenbergia, que possui flores mais numerosas e estípulas planas e eretas.

\section{Chave para as espécies de Ferdinandusa na Reserva Ducke}

1. Folhas glabras, coriáceas, de ápice arredondado. 1. F. elliptica

1'. Folhas glabras ou hirsutas, cartáceas ou subcoriáceas, de ápice acuminado a obtuso.

2. Pecíolo e folhas glabros em ambas as faces 2. F. goudotiana

2'. Pecíolo hirsuto; folhas com nervuras hirsutas em ambas as faces 3. F. hirsuta

12.1 Ferdinandusa elliptica Pohl, Pl. Bras. Icon. Descr. 2: 9, t. 106. 1828.

Árvores até $25 \mathrm{~m}$ alt. Tronco com base reta. Ritidoma marrom, sulcado; exterior da casca marrom, ca. $2 \mathrm{~mm}$ de espessura; alburno amarelado, duro. Ramos quadrangulares ou cilíndricos, glabros. Estípulas 12-25 mm compr., agudas. Folhas com pecíolo 5-20 mm compr., glabro; lâmina elíptica ou orbicular, 8-24×5,5$17 \mathrm{~cm}$, ápice arredondado, base obtusa até truncada, glabra em ambas as faces, coriácea; nervuras laterais 7-12 pares, planas em ambas as faces. Inflorescências piramidais ou arredondadas, 6-9 $\mathrm{cm}$ compr. Flores com cálice 1-2 mm compr., glabro, denteado; corola creme ou amarela, tubo estreito, 2,2-3,2 $\times 0,5$ $\mathrm{cm}$, lobos 4, 8-11 mm compr. Cápsulas 2,3$4,5 \times 1,6 \mathrm{~cm}$; sementes $1,1-1,7 \times 0,4-0,6 \mathrm{~cm}$.

Ocorre no Equador, Bolívia e Brasil. Na Reserva Ducke foi coletada em floresta de platô, com frutos jovens em junho.

27.VI.1997 (fr) Sothers et al. 1035 (INPA MO).

\subsection{Ferdinandusa goudotiana K. Schum.,} Fl. bras. 6(6): 211. 1889.

Fig 11

Arvoretas ou arbustos, 2-18 m alt. Ramos cilíndricos, glabros. Estípulas 10-25 mm compr., glabras, agudas. Folhas com pecíolo 4-7 mm compr., glabro; lâmina ovada a elíptica, 10-16×3,5-7 cm, ápice acuminado, base obtusa a subcordada, glabra em ambas as faces, cartácea; nervuras laterais 6-8 pares, salientes em ambas as faces. Inflorescências piramidais ou corimbosas, $15-20 \mathrm{~cm}$ compr. Flores com cálice 2-3,5 mm compr., glabro; corola alva ou creme, tubo estreito, 1,5-2,5 $\times$ 1-2,5 mm, lobos 4, ca. $5 \mathrm{~mm}$ compr. Cápsulas oblongas ou elipsóides, 3,5-4,5 ×0,4-0,6 mm; sementes, $1,5-2 \times 0,5-0,7 \mathrm{~cm}$.

Ocorre nas Guianas, Venezuela e no Brasil. Na Reserva Ducke foi coletada apenas em florestas de baixio, com flores em setembro e frutos em dezembro (Campos \& Brito 1999: pág. 642).

14.IX.1995 (fl) Costa \& Assunção 357 (INPA K MO NY SPF); 7.XII.1994 (fr) Vicentini \& Pereira 782 (INPA K NY SPF).

12.3 Ferdinandusa hirsuta Standl., Publ. Field Columbian Mus., Bot. Ser. 8: 158. 1930.

Árvores até $13 \mathrm{~m}$ alt. Tronco circular com pequenas raízes tabulares. Ritidoma nitidamente reticulado. Ramos quadrangulares, hirsutos. Estípulas decíduas, desconhecidas. Folhas com pecíolo 3-8 mm compr., hirsuto; lâmina elíptica ou ovada, $8-15 \times 4,5-10 \mathrm{~cm}$, ápice obtuso, agudo ou curto-acuminado, base obtusa, arredondada ou ligeiramente cordada, cartácea a subcoriácea, com nervuras principais hirsutas em ambas as faces; nervuras laterais 5-11 pares. Inflorescências corimbosas ou piramidais, 1-2,5 cm compr. Flores com cálice ca. $0,8 \mathrm{~mm}$ compr., 4-denteado, glabro; corola alva, 3,1-4,3 cm compr., tubo $1-3 \mathrm{~mm}$ larg., lobos 4. Cápsulas estreitamente oblongas, 4 $4,5 \times 2,6 \mathrm{~cm}$, glabras.

Ocorre em Manaus (Brasil) e no sudeste da Colômbia. Na Reserva, foi coletada em floresta de baixio, apenas em estado estéril, o presente registro baseia-se na determinação da 
árvore marcada como \#3750 (Campos \& Brito 1999: pág. 646).

\section{Geophila D.Don}

Ervas prostradas, hermafroditas, perenes. Ramos prostrados, com raízes na região dos nós. Estípulas interpeciolares, triangulares, inteiras ou levemente bilobadas, persistentes. Folhas opostas, geralmente longipecioladas, com lâminas arredondas a freqüentemente cordiformes. Inflorescências terminais ou axilares, subcapitadas, paucifloras, geralmente com um invólucro de brácteas. Flores bissexuais, homostilas; cálice (4)5(-7)-lobado; corola alva, infundibuliforme ou hipocrateriforme, pubescente na região da fauce, lobos (4)5(-7), prefloração valvar; estames (4)5(-7), inseridos no tubo da corola, anteras dorsifixas; ovário 2-locular, óvulos 1 por lóculo; estigma 2-partido. Frutos drupáceos, subglobosos ou elipsóides, carnosos, alaranjados a avermelhados; pirênios 2, planoconvexos, geralmente costados e torcidos.

Gênero pantropical com cerca de 20 espécies, das quais cinco ocorrem na América (Taylor et al. 2004). É facilmente reconhecível pelo hábito prostrado, folhas longipecioladas e cordiformes, inflorescência pauciflora e drupas alaranjadas a avermelhadas com dois pirênios. É semelhante à Coccocypselum no hábito herbáceo e aspecto das flores, porém Coccocypselum possui frutos bacáceos, azuis com sementes numerosas e pequenas.

\section{Chave para as espécies de Geophila na Reserva Ducke}

1 Estípulas hirsutas; ovário e frutos conspicuamente pilosos ............................. 1. G. cordifolia

1'. Estípulas glabras; ovário e frutos glabrescentes .................................................. 2. G. repens

13.1 Geophila cordifolia Miq., Stirp. Surinam. Select. 176. 1850 [1851]. $\quad$ Fig. 2a

Ervas prostradas. Ramos cilíndricos, delgados, pilosos. Estípulas deltóides, 2-3 $\times$ 1-2 mm, hirsutas. Folhas com pecíolo delgado, 2-4 cm compr., hirsuto; lâmina oval-cordada a oblongo-cordada, 2-5×1,6-3 cm, ápice obtuso a curto-acuminado, base cordada, esparsamente pilosa, nervuras pubescentes em ambas as faces; nervuras laterais 4-6 pares. Inflorescências 7-17-floras, ca. $6 \mathrm{~mm}$ compr.; pedúnculo 15 $30 \mathrm{~mm}$ compr., hirsuto. Flores com cálice 4 $5 \times 0,5-2 \mathrm{~mm}$, hirsuto, 5-lobado; corola 8-12 $\times 2 \mathrm{~mm}$, esparsamente pubescente, 5 -lobada; estames 5 , subsésseis, inseridos na porção mediana do tubo da corola; ovário hirsuto, estigma alvo. Drupas $8-12 \times 5-8 \mathrm{~mm}$, pilosas; pirênios costados, $4-5 \times 2-3 \mathrm{~mm}$.

Apresenta ampla distribuição geográfica, ocorrendo da América Central até a Colômbia, Venezuela, Peru, Equador, Guianas, Bolívia e Brasil. No Brasil ocorre principalmente na Região Norte do país. Na Reserva Ducke ocorre em florestas de baixio, vertente e platô, e floresce de dezembro a abril e frutifica de dezembro a julho (Campos \& Brito 1999: pág. 627, 631).
8.XII.1994 (fl fr) Costa et al. 35 (INPA K NY SPF); 18.III.1996 (fl fr) Campos et al. 553 (INPA NY); 1.VII.1994 (fr) Ribeiro et al. 969 (INPA NY SPF); 7.IV.1994 (fl fr) Ribeiro et al. 1256(INPANY); 9.IV.1996 (fl fr) Ribeiro et al. 1817 (INPA K MO SPF).

13.2 Geophila repens (L.) I.M.Johnst., Sargentia 8: 281. 1949.

Ervas prostradas. Ramos cilíndricos, delgados, glabros. Estípulas deltóides, orbiculares a ovadas, 1,5-2 × 1,5-2 mm, glabras. Folhas pecioladas; pecíolo 0,7-4,7 cm compr., pubescente; lâmina orbicular-cordada a oval-cordada ou subreniforme, $0,8-2,4 \times 0,9$ $2,5 \mathrm{~cm}$, ápice arredondado a agudo, base cordada, face adaxial glabra a esparsamente pubérula, face adaxial glabra, pubérulo ou estrigosa; nervuras laterais 3-5 pares. Inflorescências 2-4-floras, 1-3 cm compr.; pedúnculo 5-35 mm long. Flores com cálice 4-5 × 1-2 mm, 5-lobado, lobos lanceolados, esparsamente pubescentes; corola alva, 9-14 mm compr., glabra; estames 5, subsésseis, inseridos na porção mediana do tubo da corola; ovário glabro. Drupas 7-12 $\times 4-8 \mathrm{~mm}$, glabras; pirênios 3-4×2-3 mm. 
Pantropical, ocorrendo desde o México até a América do Sul nas Guianas, Venezuela, Colômbia, Equador, Bolívia e Brasil e também no Oeste da África, Filipinas e oeste do Pacífico. Na Reserva Ducke ocorre preferencialmente em florestas de campinaranas e beira de trilhas, e floresce e frutifica em agosto e janeiro (Campos \& Brito 1999: pág. 631). 6.I.1995 (fl fr) Costa et al. 80 (INPANY); 3.VIII.1994 (fl fr) Ribeiro \& Silva 1374 (INPA MO NY SPF).

\section{Henriquezia Spruce ex Benth.}

Árvores, arvoretas ou arbustos hermafroditas. Ramos cilíndricos, com exsudado resinoso. Estípulas interpeciolares, profundamente 1-lobadas, aparentemente livres, persistentes, segmentos estreito-deltóides a lineares. Folhas 3-6-verticiladas ou raramente pareadas, pecioladas, decussadas, com 1-2 glândulas na base do pecíolo. Inflorescências terminais, paniculiformes, em cimeiras complexas constituída de um eixo central ramificado em vários dicásios. Flores bissexuais, homostilas, levemente zigomorfas, vistosas; cálice 4-lobado, lobos ligeiramente desiguais; corola infundibuliforme, 5-lobada, prefloração imbricada, esverdeada, creme, rosada ou alva, fauce manchada e estriada e dotada de anel de tricomas; estames 5, inseridos desigualmente no tubo da corola, anteras dorsifixas, inclusas; ovário parcialmente súpero, 2-locular, óvulos 4 por lóculo. Frutos cápsulas, oblongos, achatados, lenhosos, parcialmente súperos, deiscência loculicida; sementes elípticas, achatadas, conspícuas, não aladas.

Gênero com três espécies ocorrendo preferencialmente ao longo dos rios da região amazônica das Guianas, Venezuela, Colômbia e Brasil (Rogers 1984). Este gênero, já tratado como um família distinta, pode ser reconhecido através das folhas verticiladas com o dobro do número de estípulas e 1-2 glândulas na base do pecíolo, pelas inflorescências vistosas em dicásios espiralados dispostos num eixo central, flores bem desenvolvidas, levemente zigomorfas com ovário parcialmente supero e pelas as cápsulas achatadas e relativamente grandes.
14.1 Henriquezia verticillata Spruce ex Benth., Hooker's J. Bot. Kew Gard. Misc. 6: 338. 1854.

Fig. 2b

Árvores de grande porte, emergentes, até $35 \mathrm{~m}$ alt., $75 \mathrm{~cm}$ diâm. Tronco circular, base reta, às vezes levemente acanalada, raízes tabulares presentes, assimétricas, até $1,5 \mathrm{~m}$ alt., ca. $50 \mathrm{~cm}$ larg. na base. Ritidoma marrom-avermelhado a marrom claro-alaranjado; lenticelas circulares, dispersas por todo o tronco; exterior da casca marrom, fina, ca. $0,5 \mathrm{~mm}$ de espessura; casca internamente bege-clara ou alaranjada, $8-10 \mathrm{~mm}$ de espessura; alburno alvo ou amarelado, fibroso. Ramos cilíndricos, estriados, glabros, com resina vermelha, pegajosa, principalmente nos jovens. Estípulas estreitamente triangulares ou lineares, $2,2-4,2 \times 0,1-0,2 \mathrm{~cm}$, glabras. Folhas 5-7verticiladas, pecioladas; pecíolo $1,5-2,8 \mathrm{~cm}$ compr., glabro, com uma glândula circular na base; lâmina oblonga a obovada, 11,7-17,2×3,4$8 \mathrm{~cm}$, ápice truncado a retuso e apiculado, base obtusa a subcordada, glabra em ambas as faces; nervuras laterais 9-13 pares, impressas na face adaxial, salientes na face abaxial, nervação terciária geralmente obscura. Inflorescências (6,5-) 9-11,5 cm compr. Flores odoríferas; cálice $1-1,4 \times 0,5-0,7 \mathrm{~cm}$, lobos deltóides a lanceolados, seríceos ou tomentosos em ambas as faces; corola esverdeada a alvo-rosada com máculas vermelhas e estrias amarelas na região da fauce, 4,2-6,5 × 1,1-1,7 cm., densamente tomentosa. Cápsulas 7-9 $\times 10 \mathrm{~cm}$; sementes suborbiculares a orbiculares, 4-4,5 ×5-5,5 cm.

Apresenta flores muito semelhantes àquelas observadas nas Bignoniaceae, mas pode ser facilmente diferenciada pela presença das estípulas, folhas simples e verticiladas e os estames nunca didínamos (em Henriquezia a diferença na posição dos estames deve-se ao diferente nível de inserção no tubo da corola e não ao diferente comprimento dos filamentos). Ocorre freqüentemente nas florestas de baixio às margens de igarapés e rios na região sudoeste da Venezuela e na região do rio Negro no Brasil. Na Reserva Ducke ocorre ao longo do curso dos igarapés Barro Branco e principalmente no Acará, tendo sido coletada apenas com flores nos meses de outubro e novembro (Campos \& Brito 1999: pág. 626, 632). 


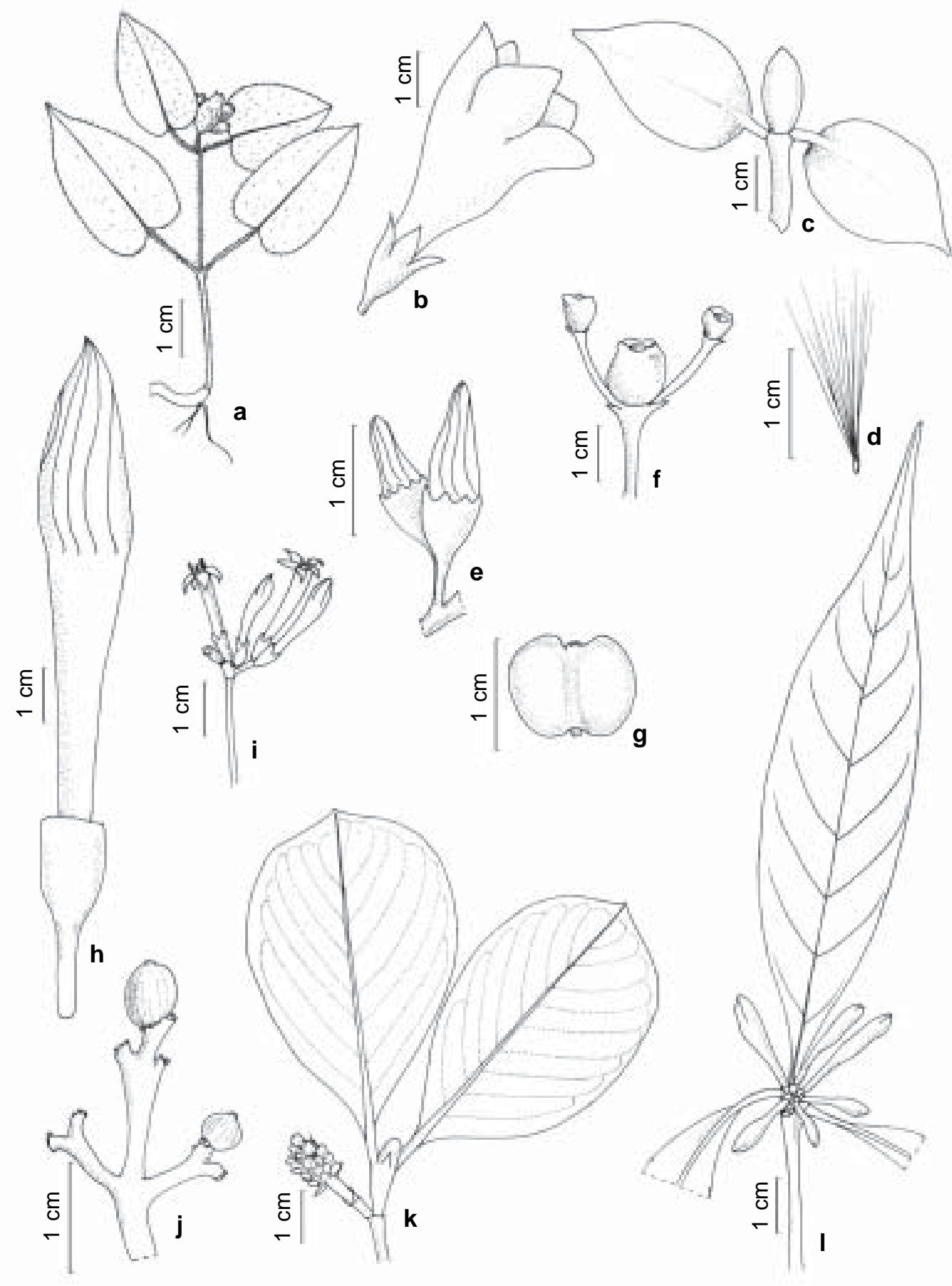

Figura 2 - a. Geophila cordifolia, planta em fruto (Costa 35); b. Henriquezia verticillata, vista lateral da flor zigomorfa (Vicentini 370); c-d. Hillia ulei, c. ápice do ramo com estípula, d. Semente comosa (Egler 46683); e. Ibetralia surinamensis, detalhe da inflorescência (Ducke 22916); f. Isertia hypoleuca, detalhe da infrutescência (Campos 531); g. Ixora ulei, fruto (Ferreira 118); h. Kutchubaea sericantha, botão floral (Ribeiro 1831); i. Ladenbergia amazonensis, detalhe da inflorescência (Cordeiro 1554); j. Margaritopsis boliviana, detalhe da infrutescência (Campos 526); k. Malanea sarmentosa, parte apical do ramo com inflorescência (Ackerly 117); 1. Morinda triphylla, parte apical do ramo com inflorescência (Ducke 23210). 
25.XI.1994 (fl) Assunção 91 (INPA K MO NY SPF); 12.XI.1993 (fl) Vicentini \& Assunção 370 (INPA K MO NY SPF); 28.X.1994 (fl) Sothers \& Silva 252 (INPA K MONY).

\section{Hillia Jacq.}

Arbustos hermafroditas, suculentos, geralmente epifíticos. Ramos quadrangulares ou cilíndricos. Estípulas interpeciolares, liguladas a oblanceoladas, decíduas. Folhas opostas, decussadas, subsésseis ou pecioladas, suculentas. Inflorescências terminais, 1(3)floras. Flores bissexuais, homostílicas; cálice reduzido ou 4-10-lobado; corola salverforme a infundibuliforme, alva, esverdeada, amarela, laranja ou vermelha, glabra, 4-10-lobada, prefloração contorta; estames 4-7, inseridos na porção mediana ou superior do tubo da corola, anteras basifixas; ovário 2-locular, óvulos muitos por lóculo; estigma 2-partido. Frutos capsulares, estreitamente oblongos, cartáceos, deiscência septicida; sementes numerosas, fusiformes a elípticas, comprimidas, aladas, comosas (dotadas de um tufo de tricomas no ápice).

Gênero com 24 espécies de arbustos epifíticos amplamente distribuídas no neotrópico (Taylor 1994), Hillia é facilmente reconhecido pelo hábito epifítico, as folhas suculentas com a nervação pouco evidente, flores vistosas, solitárias, e as sementes com tufo de tricomas. Cosmibuena é semelhante, porém distingue-se por suas flores agrupadas em cimeiras e pelas sementes sem tufo de tricomas. Campos \& Brito (1999: pág. 631) incluíram uma outra espécie no Guia de Identificação, como "Hillia sp. 1"; porém estudos mais aprofundados mostraram tratar-se de Cosmibuena grandiflora.

15.1 Hillia ulei K. Krause, Verh. Bot. Vereins Prov. Brandenburg 50: 97. 1908. Fig 2c-d Hillia viridiflora Kuhlm. \& Silveira, Arch. Jard. Bot. Rio de Janeiro 4: 370, t. 34. 1925.

Hillia irwinii Steyerm., Mem. New York Bot. Gard. 23: 287. 1972.

Hillia schultesii Steyerm., Mem. New York Bot. Gard. 23: 287. 1972.

Arbustos epifíticos, suculentos. Ramos glabros, cilíndricos. Estípulas oblanceoladas ou obovadas, $0,5-1,7 \times 0,1-0,8 \mathrm{~mm}$, glabras. Folhas pecioladas; pecíolo 1-1,5 cm compr.; lâmina elíptica a estreito lanceolada, 6-8,5 $\times$ $1,5-2,5 \mathrm{~cm}$, glabra, ápice agudo, base cuneada; nervuras laterais 5-7 pares, com origem na metade basal da lâmina. Flores aparentemente noturnas; cálice glabro, ca. $1 \mathrm{~cm}$ compr., $7-$ 10-lobado; corola infundibuliforme, amareloesverdeada, 3,4-4,3 cm compr., 7-10-lobada, lobos arredondados. Cápsulas oblongas, ca. 10 $\times 1 \mathrm{~cm}$, glabras; sementes numerosas, ca. $1 \times$ $0,5 \mathrm{~mm}$, tricomas ca. $1 \mathrm{~cm}$ compr.

Ocorre esporadicamente nas florestas tropicais, frequientemente ao longo dos rios da América do Sul: na Bolívia, Colômbia, Equador, Peru, Guiana Francesa, Suriname, Venezuela e Brasil (Taylor 1994). No Brasil, sua ocorrência é conhecida no Paraná, Rio de Janeiro, Amapá e Amazonas. Na Reserva Ducke foi encontrada na floresta de vertente, tendo sido coletado apenas com frutos em janeiro. Floresce de dezembro a janeiro e maio a julho e frutifica de janeiro a março (Taylor 1994). Campos \& Brito (1999: pág. 627, 631). 30.I.1996 (fr) Ribeiro et al. 1789 (INPA NY).

Material adicional examinado: BRASIL. AMAPÁ: Rio Jari, Cachoeira Macacoara $0^{\circ} 53^{\prime} \mathrm{N}, 53^{\circ} 21^{\prime} \mathrm{W}$, 200 m, 26.VIII.1961 (fr) Egler \& Irwin 46683 (INPA K NY - material-tipo de H. irwinii).

\section{Ibetralia Bremek.}

Arvoretas ou arbustos dióicos. Ramos cilíndricos, sem exsudato resinoso. Estípulas unidas ao redor do caule, triangulares ou liguladas, decíduas. Folhas opostas, pecioladas, decussadas. Inflorescências estaminadas terminais, cimosas a subcapitadas. Flores estaminadas com cálice seríceo no interior, 56-lobado; corola salverforme, alva, serícea externamente, serícea no interior na porção distal, 6-lobada, prefloração contorta; estames 6, inseridos na região da fauce, anteras dorsifixas; pistilódio similar ao estigma; ovário estéril. Inflorescências pistiladas terminais, 1-floras. Flores pistiladas com cálice e corola semelhantes aos das flores estaminadas ou de tamanho menor; estaminódios semelhantes aos estames; ovário 1-2-locular, óvulos muitos por 
lóculo; estigma 2-partido. Frutos bacáceos, globosos a elipsóides, coriáceos, de cor desconhecida; sementes numerosas, comprimidas, envolvidas numa polpa gelatinosa.

Gênero monotípico registrado nas Guianas no Brasil (Boom \& Delprete 2002). As estípulas decíduas, flores unissexuais e frutos globosos são características marcantes do gênero. Ibetralia é próxima de Alibertia e Kutchubaea; diferindo de ambas por não apresentar ramos resinosos, e particularmente de Kutchubaea devido ao seu porte arbustivo ou de arvoreta. Estas entidades taxonômicas são pouco conhecidas e existe a possibilidade de que um estudo mais aprofundado não apresente argumentos suficientes para reconhecê-las a nível genérico.

16.1 Ibetralia surinamensis Bremek., Recueil Trav. Bot. Néerl. 31: 266. $1934 . \quad$ Fig. 2e Alibertia surinamensis (Bremek.) Steyerm., Mem. N.Y. Bot. Gard. 23: 355. 1972. Kutchubaea surinamensis (Bremek.) C.H. Perss., Revista de Biologia Neotropical 2(2): 67.2005.

Alibertia dolichophylla Standl., Publ. Field Mus. Bot. 22: 107. 1940.

Arvoretas ou arbustos, ca. $5 \mathrm{~m}$ alt., ca. $3 \mathrm{~cm}$ diâm. Ritidoma marrom-acinzentado, liso; exterior da casca fina; casca internamente alva, ca. $1 \mathrm{~mm}$ de espessura; alburno alvo; odor suave. Ramos glabros, escamosos. Estípulas 5-11×4 $5 \mathrm{~mm}$, glabras a esparsamente pubescentes. Folhas com pecíolo de 1,2-1,5 cm compr.; lâmina lanceolada a estreito-lanceolada, 20-25 $\times 7-8,2 \mathrm{~cm}$, ápice acuminado, base cuneada a decurrente, glabra na face adaxial, densamente pubérula na face abaxial; nervuras laterais 9-12 pares. Inflorescências estaminadas 1-2 cm compr. Flores estaminadas com tubo do cálice sinuoso, 4-5 mm compr.; corola com tubo ca. 1 cm compr., 3-4 mm diâm., lobos estreitamente triangulares, ca. $1 \mathrm{~cm}$ compr. Flores pistiladas com pedúnculo 5-8 mm compr.; cálice ca. $6 \mathrm{~mm}$ compr.; corola com tubo ca. $1 \mathrm{~cm}$ compr., 3-4 mm diâm., lobos ca. 1 cm compr. Bagas 3,5$5,5 \times 2,5-3 \mathrm{~cm}$.

Este táxon foi previamente determinado de maneira errônea como Kutchubaea insignis Fisch. ex DC. (Campos \& Brito, 1999: pág. 626, 640), e o nome I. surinamensis é utilizado aqui de modo provisório. De acordo com Persson (2005), esta espécie pertence ao gênero Kutchubaea, mas a classificação do mesmo permanece instável e optamos por posicioná-la em Ibetralia. De qualquer modo, é fácil distinguir as espécies de Kutchubaea e Ibetralia na Reserva Ducke através de características da corola, que é 8-10-lobada e com tubo longo em Kutchubaea e 4-6-lobada e com tubo curto em Ibetralia. Na Reserva Ducke, I. surinamensis foi coletada na floresta de vertente e floresta de baixio, com flores em agosto e frutos em abril. 3.IV.1996 (fr) Vicentini \& Silva 1173 (INPA MO NY SPF); 29.VIII.1996 (fl) Costa \& Silva 563 (INPAMO). Material adicional examinado: BRASIL. PARÁ: Juruty Velho, 29.VII.1927 (fl) Ducke 22916 (K RB - material-tipo de Alibertia dolichophylla Standl.).

\section{Isertia Schreb.}

Árvores ou arbustos hermafroditas. Ramos cilíndricos ou quadrangulares, às vezes com exsudado resinoso. Estípulas persistentes, intrapeciolares, às vezes profundamente bilobadas na região interpeciolar e então aparentando 4 estípulas livres. Folhas opostas ou verticiladas, pecioladas, decussadas. Inflorescências terminais, em tirsos subpaniculados ou tirsos racemosos, os ramos terminais em dicásios ou cimeiras escorpióides. Flores bissexuais, homostílicas, vistosas; cálice truncado ou 4-6-lobado; corola tubulosa ou hipocrateriforme, alva, laranja ou vermelha, vilosa na fauce, 5-6 (7)-lobada, prefloração valvar ou imbricada; estames 4-7, inseridos na região da fauce da corola, anteras dorsifixas, loceladas; ovário 2-6 (7)-locular, óvulos muitos por lóculo; estigma 2-6 (7)-partido. Frutos drupáceos ou bacáceos, globosos, carnosos, quando drupáceos com 2-6 pirênios 1-loculares; sementes numerosas, angulosas.

Compreende 14 espécies neotropicais, ocorrendo principalmente em florestas secundárias da América Central e no norte da América do Sul (Boom 1984). Pode ser reconhecido pelas estípulas intrapeciolares (às vezes profundamente bilobadas e 
aparentemente livres), inflorescências terminais multifloras, flores vistosas com tubo da corola bem desenvolvido, anteras loceladas, cujas tecas não são contínuas e, sim, divididas em pequenas celas, frutos bacáceos com muitas sementes pequenas imersas na polpa ou drupas com pirênios multisseminados. Isertia é superficialmente semelhante a Palicourea, que difere na presença de estípulas interpeciolares (não intrapeciolares), anteras não loceladas, e pirênios unisseminados.

\section{Chave para as espécies de Isertia na Reserva Ducke}

1. Estípulas 4 por nó, quase completamente livres; lâmina discolor, elíptica a oval, 9-12 cm larg ... 1. I. hypoleuca

1'. Estípulas 2 por nó, inteiras na região intrapeciolar; lâmina concolor, estreito-lanceolada, 5-7,5 cm larg.

2. I. rosea

17.1 Isertia hypoleuca Benth., Hooker's J. Bot. Kew Gard. Misc. 3: 220. 1841. Fig. 2f Árvores ou arvoretas até $15 \mathrm{~m}$ alt., 20-35 cm diâm. Tronco circular, base digitada. Ritidoma marrom, liso, escamoso; exterior da casca marrom, ca. $1 \mathrm{~mm}$ de espessura; casca internamente avermelhada, rígida, ca. $5 \mathrm{~mm}$ de espessura; alburno alaranjado, fibroso; odor agradável. Ramos fracamente quadrangulares, glabros a esparsamente pubescentes, estriados. Estípulas 4, quase completamente livres, estreito-triangulares, $8-11 \times 0,8 \mathrm{~cm}$. Folhas opostas ou raramente verticiladas, discolores, longamente pecioladas; pecíolo $3-5,5 \mathrm{~cm}$ compr.; lâmina elíptica a oval, 18-31 ×9$12 \mathrm{~cm}$, ápice acuminado, base atenuada a decurrente, face adaxial glabra, face abaxial alvo-canescente; nervuras laterais 24-27 pares. Inflorescências ca. $16 \mathrm{~cm}$ compr., ramos terminais em cimeiras escorpióides 3-floras. Flores subsésseis ou pediceladas; cálice verde-amarelado, 4-6 mm compr., truncado, pubérulo; corola vermelha, 4,56,5 cm compr., pubérula, 6-7-lobada; estames 6-7, anteras oblongas; estigma 5-6-partido. Frutos drupáceos, ovóides, ca. $1 \times 1 \mathrm{~cm}$, negros; pirênios multisseminados, $8-11 \mathrm{~mm}$ compr.; sementes ca. $1 \mathrm{~mm}$ compr.

Esta espécie ocorre nas regiões amazônicas do Venezuela, Guianas, Colômbia, Peru, Bolívia e Brasil, nos estados de Rondônia e Amazonas onde é chamada popularmente de "jambo da mata". Na Reserva ocorre nas áreas degradadas e floresce em março (Campos \& Brito 1999: pág. 626, 638). 5.III.1996, Campos \& Silva 531 (INPA MO NY SPF).

17.2 Isertia rosea Spruce ex K.Schum., Fl. bras. 6(6): 284. 1889.

Árvores, ca. $10 \mathrm{~m}$ alt. Ramos cilíndricos, glabros a esparsamente pubescentes, resinosos. Estípulas 2, intrapeciolares, ca. $4 \times$ $5 \mathrm{~mm}$. Folhas opostas, concolores, pecioladas; pecíolo 4-5 cm; lâmina estreito-lanceolada, 24-32 × 5-7,5 cm, glabra a esparsamente pubescente, ápice acuminado, base atenuada a decurrente; nervuras laterais 11-16 pares. Inflorescência ca. $8,5 \mathrm{~cm}$ compr., em dicásios, com ramos terminais escorpióides. Flores subsésseis ou pediceladas; cálice avermelhado, 3-3,5 cm compr., truncado, geralmente glabro; corola rosada a vermelha, $3,5-5,5 \mathrm{~cm}$ compr., com tricomas amarelos na região da fauce, 5-6-lobada; estigma 4-6partido. Frutos drupáceos, globosos, 8-9 mm diâm., negros, glabros; pirênios triangulares; sementes numerosas, 1,2-1,4 mm compr.

Esta espécie ocorre na região amazônica da Colômbia, Peru, Venezuela e Brasil, nos estados do Acre e Amazonas (Boom 1984). Foi coletada com flores na Reserva em maio, não tendo sido recoletada recentemente. 25.V.1961 (fl) Rodrigues \& Lima 2646 (INPA). 
18. Ixora L.

Arbustos ou arvoretas hermafroditas. Ramos cilíndricos ou quadrangulares. Estípulas interpeciolares ou às vezes curtamente unidas ao redor do caule, triangulares, persistentes. Folhas opostas ou ternadas, sésseis ou pecioladas, decussadas, com pecíolos articulados na base. Inflorescências terminais, às vezes produzidas num ramo curto $\mathrm{e}$ aparentemente axilar, cimosas, fasciculadas, paniculadas ou subcapitadas. Flores bissexuais, distílicas, freqüentemente odoríferas; cálice 4lobado; corola salverforme, alva, rosada, avermelhada ou amarela, tubo estreito, 4-lobada, prefloração contorta; estames 4 , inseridos na região da fauce da corola, anteras dorsifixas, exsertas; ovário 2-locular, óvulos 1 por lóculo; estigma 2-partido. Frutos drupáceos, subglobosos, carnosos ou coriáceos, vermelhos a negros; pirênios 2, plano-convexos, lisos, 1loculares.

Gênero pantropical com cerca de 400 espécies, a maior parte delas registradas na África e nas ilhas do Pacífico (Taylor et al. 2004), com aproximadamente 50 espécies neotropicais, ocorrendo no Caribe, México, Brasil, Bolívia e Paraguai. O gênero Ixora pode ser facilmente reconhecido através dos pecíolos articulados na base, estípulas persistentes com ápice agudo ou aristado, inflorescências cimosas às vezes coloridas, corola com 4 lobos e frutos drupáceos com 2 pirênios. Algumas espécies asiáticas são freqüentemente utilizadas como plantas ornamentais, devido à beleza e o colorido das flores. Trata-se de um gênero pouco estudado nos Neotrópicos e é possível que existam outras espécies na área da Reserva, além daquelas descritas abaixo.

\section{Chave para as espécies de Ixora na reserva Ducke}

1. Corola com tubo 9-10 mm compr.; folhas elípticas, 8,5-13 cm larg., nervuras laterais $6-10$ pares

1'. Corola com tubo ca. $11 \mathrm{~mm}$ compr.; folhas lanceoladas, elíptico-oblongas ou estreitamente elípticas, 5-9 cm larg., nervuras laterais 13-17 pares 2. I. ulei

18.1 Ixora panurensis Müll. Arg., Flora 58: 454, 458. 1875.

Arvoretas ou arvoretas 3-10 m alt., 5$10 \mathrm{~cm}$ diâm. Tronco circular, de base reta, digitada ou dilatada. Ritidoma marrom, reticulado, escamoso ou rígido, com lenticelas em pequena quantidade; casca internamente bege a marrom-alaranjada, escurecendo externamente; alburno creme ou esbranquiçado. Ramos cilíndricos, escamosos, glabros. Estípulas 9-10 $\times 4-6 \mathrm{~mm}$, glabras. Folhas opostas, pecioladas; pecíolo $0,8-1,8 \mathrm{~cm}$ compr., glabro; lâmina elíptica, 18-25×8,5-13 cm, subcoriácea, ápice acuminado, base obtusa a cuneada, margem revoluta, glabra em ambas as faces; nervuras laterais 6-8(-10) pares. Inflorescências terminais ou aparentemente axilares, em panículas 3-ramificadas, 3-4,5 cm compr., pedunculadas, pubérulas. Flores subsésseis; cálice curtodenteado, ca. $1 \times 1 \mathrm{~mm}$; corola amarelo-parda ou rosada, externamente pubérula, tubo $9-10 \times 1 \mathrm{~mm}$, lobos arredondados, ca. $4 \mathrm{~mm}$ compr. Drupas vermelhas, 5-10×8-11 mm, glabras, às vezes ligeiramente bilobadas; pirênios 4-6×3-4 mm.

Amplamente distribuída na região amazônica. No Brasil ocorre nos estados do Amazonas, Roraima, Acre e Maranhão. Foi inicialmente determinada erroneamente por Campos \& Brito (1999: pág. 626, 642) sob o nome I. ulei K. Krause. Na Reserva Ducke, I. panurensis apresenta variação no tamanho e forma das folhas e no número de nervuras laterais. Ocorre nas florestas de baixio, vertente, campinarana e platô. Floresce em julho e frutifica em fevereiro, março, julho e outubro.

15.II.1996 (fr) Campos et al. 495 (INPA NY); 20.VII.1995 (fl) Costa et al. 325 (INPA NY); 19.III.1996 (fr) Campos et al. 556 (INPA NY); 22.VII.1994 (fr) Vicentini et al. 645 (INPA MO NY); 15.II.1996 (fr) Campos et al. 498 (INPA NY SPF); 13.IX.1996 (fl) Assunção et al. 392 (MO SPF). 
18.2 Ixora ulei K. Krause, Notizbl. Bot. Gart. Berlin-Dahlem 6: 205.1914.

Fig. $2 \mathrm{~g}$

Arbustos ou arvoretas 0,5-2,5 m alt. Tronco irregular, base reta ou digitada. Ritidoma marrom ou marrom-escuro, desprendendo-se por placas, sem lenticelas; finamente reticulado; exterior da casca marrom, fina; casca internamente castanha, bege a alaranjada, alburno amareloesbranquicado, fibroso. Ramos cilíndricos, glabros. Estípulas 2-5 × 7-10 mm, glabras, aristadas. Folhas opostas, pecioladas; pecíolo 0,7-1,5 cm; lâmina lanceolada, estreito-elíptica ou elíptico-oblonga, 16-26 × 5-9 cm, ápice agudo a acuminado, base cuneada a aguda, margem às vezes revoluta, glabra em ambas as faces; nervuras laterais 13-17 pares. Inflorescências terminais, em panículas 3ramificadas, $3-5 \mathrm{~cm}$ compr., pedunculadas, hirtelas ou pubérulas. Flores subsésseis; cálice curto-denteado, ca. $1 \times 1 \mathrm{~mm}$; corola amarela com tubo às vezes avermelhado, externamente pubérula, tubo ca. $11 \mathrm{~mm}$ compr., ca. 1 mm diâm., lobos arredondados, 3-4 mm compr. Drupas vermelhas passando a enegrecidas quando maduras, $8-10 \times 8 \mathrm{~mm}$, ligeiramente bilobadas.

Amplamente distribuída na região amazônica. Foi erroneamente identificada por Campos \& Brito (1999: pág. 626, 642) como I. intensa K. Krause. Na Reserva Ducke ocorre nas florestas de platô e vertente. Foi coletada com flores em julho e com frutos de fevereiro a julho e novembro.

27.IV.1994 (fr) Ribeiro et al. 1285 (INPA NY); 6.VII.1993 (fl) Ribeiro et al. 1043 (INPA NY); 15.II.1996 (fr) Campos 495 (INPA SPF); 19.III.1996 (fr) Campos 556 (INPA SPF); 20.VII.1995 (fr) Costa 325 (INPA SPF) 10.II.1994 (fr) Ribeiro 1203 (INPA NY SPF); 25.IV.1996 (fl) Sothers et al. 853 (INPA SPF). 3.VII.1997 (fl) Souza 371 (INPA MO); 17.XI.1999 (fr) André et al. 3188 (INPA SP).
Material adicional examinado: BRASIL. AMAZONAS: Manaus, Com. Nossa Senhora de Fátima, Rio Tarumã-Mirim, $3^{\circ} 02^{\prime \prime} \mathrm{S}, 60^{\circ} 17^{\prime} \mathrm{W}$, 31.I.1992, L.V. Ferreira 118 (INPA K).

19. Kutchubaea Fisch. ex DC.

Árvores dióicas. Ramos cilíndricos, com exsudado resinoso amarelado. Estípulas interpeciolares ou às vezes unidas ao redor do caule, triangulares ou liguladas, persistentes. Folhas opostas, pecioladas, decussadas. Inflorescências estaminadas terminais, corimbosas, fasciculadas ou raramente capitadas. Flores estaminadas vistosas; cálice truncado ou curto-6-10-denteado; corola hipocrateriforme, alva, creme ou amarela, serícea ou vilosa no interior da fauce, 6-11-lobada, prefloração contorta; estames 611, inseridos na região da fauce, anteras dorsifixas; pistilódio similar ao estigma; ovário estéril. Inflorescências pistiladas terminais, 1(-3)-floras. Flores pistiladas com cálice e corola semelhantes aos das flores estaminadas ou de tamanho menor; estaminódios semelhantes aos estames; ovário 1-2-locular, óvulos muitos por lóculo, estigma inteiro ou 2-partido. Frutos bacáceos, globosos a elipsóides, coriáceos a lenhosos, de cor desconhecida; sementes numerosas, comprimidas, envolvidas numa polpa gelatinosa.

Gênero com cerca de 11 espécies distribuídas na região tropical da América do Sul, principalmente no Brasil (Taylor 2004), caracterizado pela presença de exsudato amarelado nos ramos jovens, estípulas persistentes e unidas ao redor do caule, flores vistosas, unissexuais, com grande número de lobos e os frutos globosos bem desenvolvidos. Kutchubaea é próximo do gênero Ibetralia (ver comentários acima). O epíteto genérico aparece erroneamente como "Kotchubaea" na literatura.

\section{Chave para as espécies de Kutchubaea na Reserva Ducke}

1. Folhas elípticas; nervuras laterais livres; estípulas 4-7 mm compr.

1. K. duckei

1'. Folhas oblanceoladas; nervuras laterais unidas às nervuras submarginais; estípulas 12-15 mm compr. 2. K. sericantha 
19.1 Kutchubaea duckei Steyerm., Mem. New York Bot. Gard. 10(5): 216. 1963.

Árvores $15-30 \mathrm{~m}$ alt., $30 \mathrm{~cm}$ diâm. Tronco circular com raízes tabulares. Ritidoma marrom escuro, fibroso; exterior da casca marrom-escura, 1-2 $\mathrm{mm}$ de espessura; casca internamente creme com estrias alaranjadas, ca. $5 \mathrm{~mm}$ de espessura; alburno creme; exsudato amarelo, escasso, hialino, pegajoso. Ramos cilíndricos, glabros, os jovens resinosos. Estípulas deltóides, 4-7 × 5-7 mm. Folhas pecioladas; pecíolo 1-2 cm compr.; lâmina elíptica, $11-25 \times 6,5-15 \mathrm{~cm}$, ápice obtuso a curto-acuminado, base cuneada a obtusa, glabra em ambas as faces; nervuras laterais 7-13 pares, distalmente livres. Inflorescências estaminadas cimosas, pedunculadas; pedúnculo 1-10 $\mathrm{mm}$ compr. Flores estaminadas com pedicelos $0,2-2 \mathrm{~cm}$ compr.; cálice truncado, 0,9-1,3 cm compr.; corola creme ou alvo-amarelada, externamente serícea, tubo 2,5-4,5 ×0,3-0,5 mm, 7-9-lobada, estreitamente triangulares, $3-3,2 \mathrm{~cm}$ compr.

Flores pistiladas e frutos não vistos.

Ocorre apenas na amazônia brasileira e, no Guia de Identificação, Campos \& Brito (1999: pág. 640) a determinaram erroneamente sob o nome $K$. semisericea. Na Reserva Ducke, ocorre nas florestas de baixio e de vertente. Foi coletada apenas com flores estaminadas em março e junho.

22.III.1994 (fl) Ribeiro et al. 1237 (INPA MO NY

SPF); 23.VI.1994 (fl) Vicentini \& Assunção 584 (INPAMO NY SPF).

19.2 Kutchubaea sericantha Standl., Publ. Field Columbian Mus., Bot. Ser. 8(5): 355. 1931.

Fig. 2h

Árvores $12-18 \mathrm{~m}$ alt., $15-25 \mathrm{~cm}$ diâm. Tronco circular de base acanalada. Ritidoma marrom-avermelhado, estriado; exterior da casca marrom, ca. 0,5 $\mathrm{mm}$ de espessura; casca internamente rosada, 3-4 $\mathrm{mm}$ de espessura; alburno amarelo. Ramos cilíndricos, estriados, glabros. Estípulas deltóides, 1,2-1,5×1-1,2 cm, glabras a pubérulas. Folhas coriáceas, pecioladas; pecíolo $2-4 \mathrm{~cm}$ compr., glabro ou pubérulo; lâmina oblanceolada, 24,3-34,8 × 7,6-15,3 cm., ápice agudo a acuminado, base cuneada a decurrente, glabra em ambas as faces ou pubérula na face abaxial; nervuras laterais 12 18 (-22) pares, unidas distalmente às nervuras submarginais. Inflorescências estaminadas fasciculadas, 7-11-floras; pedúnculo 1-2,5 cm compr. Flores estaminadas com pedicelos 1,5-2 cm compr.; cálice truncado ou sinuoso, 1-1,1 cm compr.; corola creme-amarelada, densamente serícea externamente, tubo 4,55,5 cm compr., 6-8 mm diâm., 8(9)-lobada, lobos estreitamente triangulares, $0,8-3 \mathrm{~cm}$ compr. Flores pistiladas solitárias, subsésseis; cálice e corola semelhantes aos das flores estaminadas. Bagas oblongo-elipsóides, ca. $7 \times 3,5 \mathrm{~cm}$; sementes $1-1,5 \mathrm{~cm}$ compr.

Ocorre na região amazônica da Venezuela, Peru, Colômbia e Brasil. Na Reserva Ducke foi coletada nas florestas de baixio, vertente, platô e campinarana. Floresce de maio a julho e frutifica em fevereiro, maio e julho (Campos \& Brito 1999: pág. 640).

10.II.1996 (fr) Campos et al. 475 (INPA MO NY); 12.V.1988 (fl) Nelson 1601 (INPA NY); 3.V.1994 (fr) Ribeiro et al. 1300 (INPA NY); 3.VII.1995 (fl) Sothers et al. 504 (INPA NY); 31.V.1994 (fl) Vicentini et al. 562 (INPA MO NY SPF); 29.V.1996 (fl) Ribeiro \& Assunção 1831 (INPA K MO SPF).

\section{Ladenbergia Klotzsch}

Árvores ou arvoretas hermafroditas. Ramos cilíndricos ou quadrangulares. Estípulas interpeciolares e às vezes unidas ao redor do caule, geralmente bem desenvolvidas, triangulares a obovadas, decíduas. Folhas opostas ou raramente ternadas, pecioladas, decussadas. Inflorescências terminais ou nas axilas das folhas distais, paniculadas. Flores bissexuais, odoríferas, noturnas, distílicas; cálice truncado ou 5-6-denteado; corola salverforme, alva, glabra no interior, 5-7lobada, lobos frequentemente papilosos, prefloração valvar; estames 5-7, inseridos na porção mediana do tubo da corola, anteras dorsifixas, inclusas; ovário 2-locular, óvulos muitos por lóculo; estigma 2-partido. Frutos capsulares, oblongos ou cilíndricos, cartáceos ou lenhosos, deiscência septicida; sementes numerosas, achatadas, aladas. 
Gênero com cerca de 35 espécies distribuídas na América Central e do Sul (Andersson 1997, Taylor et al. 2004). As principais características deste gênero são as estípulas bem desenvolvidas, eretas e decíduas, as inflorescências terminais, flores alvas, noturnas e glabras internamente e o fruto capsular com numerosas sementes aladas.

\subsection{Ladenbergia amazonensis Ducke,} Trop. Woods 31: 21. 1932.

Fig. 2i

Árvores, 20-30 m alt., 35-50 cm diâm. Tronco circular ou acanalado. Ritidoma fissurado ou levemente sulcado, com lenticelas conspícuas, circulares, salientes; exterior da casca marrom-escura, ca. $2 \mathrm{~mm}$ de espessura; casca internamente avermelhada, 5-6 $\mathrm{mm}$ de espessura; alburno creme, com exsudato transparente, escasso, pegajoso. Ramos cilíndricos, glabros, marrom-acinzentados. Estípulas triangulares, $1,5-3 \times 0,6-0,8 \mathrm{~cm}$, externamente estrigulosas. Folhas opostas, pecioladas; pecíolo 1,5-3,5 cm compr.; lâmina elíptica, $10-13 \times 5-8,5 \mathrm{~cm}$, coriácea, ápice arredondado, base arredondada a obtusa, glabra em ambas as faces; nervuras laterais 7-9 pares, impressas na face adaxial, salientes na face abaxial. Inflorescências multifloras, $10-18 \mathrm{~cm}$ compr. Flores pediceladas; pedicelos $1-3 \mathrm{~mm}$ compr.; cálice 3-5 × 1,5-3 mm, lobos 5, triangulares; corola alva a creme, ca. $3 \times 0,15$ $\mathrm{mm}$, lobos 5; estames 5, subsésseis; estigma bipartido. Cápsulas lanceolóides, 4-6×1-2 cm, papiráceas; sementes 1,5-2 $\times 1-1,5 \mathrm{~mm}$.

Ocorre na Venezuela, Peru e Brasil, nos estados do Acre, Rondônia, Roraima e Amazonas. $\mathrm{NaReserva} \mathrm{foi} \mathrm{coletada} \mathrm{na} \mathrm{floresta} \mathrm{de} \mathrm{campinarana,}$ com flores de março a maio e com frutos em agosto (Campos \& Brito 1999: pág. 645).
12.III.1996 (fl) Campos \& Silva 541 (INPA K MO NY SPF); 14.V.1995 (fl) Cordeiro et al. 1554(INPAKMONY SPF), 27.VIII.1995 (fr) Vicentini et al. 1237 (INPAMO).

\section{Malanea Aubl.}

Lianas ou às vezes arbustos escandentes, hermafroditas. Ramos cilíndricos. Estípulas interpeciolares, triangulares a liguladas, decíduas, frequientemente seríceas ou velutinas. Folhas opostas, pecioladas, decussadas, com a nervação terciária paralela. Inflorescências axilares, cimosas, espiciformes ou paniculadas. Flores bissexuais, homostílicas ou distílicas; cálice truncado ou 4-lobado; corola rotácea ou infundibuliforme, alva, creme, esverdeada ou alvo-amarelada, vilosa na fauce e nos lobos, 4lobada, prefloração valvar; estames 4 , inseridos na região da fauce do tubo da corola, anteras dorsifixas, inclusas ou exsertas; ovário 2-locular, óvulos 1 por lóculo, estigma 2-partido. Frutos drupáceos, elipsóides, cilíndricos ou oblongos, carnosos, roxos ou negros; pirênio 1 ou 2, 1-2locular, liso ou costado; sementes cilíndricas.

Gênero neotropical com cerca de 35 espécies nativas da América Central e do Sul (Taylor et al. 2004). As principais características de Malanea são a nervação terciária paralela o hábito escandente, estípulas interpeciolares arredondadas a espatuladas (raramente agudas), inflorescências axilares e frutos drupáceos. Pode ser confundido com Chomelia (que possui flores maiores e frequientemente ramos armados) e Sabicea (que possui bagas com muitas sementes). Campos \& Brito (1999: pág. 629) incluíram uma outra espécie sob "Malanea sp. 2". Trata-se de apenas uma coleta de material estéril, cuja identidade ainda não foi possível confirmar, portanto este táxon não foi incluído no presente trabalho.

\section{Chave para as espécies de Malanea}

1. Estípulas agudas 1. M. duckei

1'. Estípulas arredondadas.

2. Estípulas e folhas estrigosas na face abaxial, nervuras secundárias 10-11 pares

2'. Estípulas hirsutas; folhas densamente velutinas na face abaxial, nervuras secundárias 6-8 pares 
21.1 Malanea duckei Steyerm., Publ. Field Mus. Nat. Hist., Bot. Ser. 22: 117. 1940.

Lianas lenhosas. Ramos cilíndricos ou ligeiramente quadrangulares, hirsutos ou tomentosos. Estípulas ligulado-lanceoladas a triangulares, decíduas, hirsutas na face abaxial, 4-7 $\times 3-4 \mathrm{~mm}$, agudas. Folhas com pecíolo 0,8$1,6 \mathrm{~cm}$ compr., hirsuto ou tomentoso; lâmina elíptica, $10-13,2 \times 5,5-7,6 \mathrm{~cm}$, face adaxial glabra, exceto pelas nervuras seríceas, face abaxial hirsuta, ápice obtuso, base obtusa a aguda; nervuras laterais 9-10 pares, impressas na face adaxial. Inflorescências tirsóides a paniculadas, piramidais, 4-9 cm compr.; ramos velutinos. Flores pequenas; cálice campanulado, glabro, ca. $1 \mathrm{~mm}$ compr., subtruncado; corola alva, externamente serícea, internamente com tricomas alvos, 4-5 mm compr. Drupas jovens cilíndricas, ca. $10 \times 3 \mathrm{~mm}$.

Ocorre na região de Manaus, e foi tratada em Campos \& Brito (1999: pág. 629) como "Malanea cf. macrophylla", tendo sido registrada por eles como componente da floresta de vertente. No entanto, o único espécime coletado na Reserva Ducke foi encontrado na floresta de baixio, com frutos jovens em julho. 15.VII.1998 (fr) Sothers 1103 (INPAMO).

21.2 Malanea hypoleuca Steyerm., Mem. New York Bot. Gard. 12: 251. 1965.

Lianas lenhosas, até $3 \mathrm{~cm}$ diâm. Tronco acanalado. Ritidoma esbranquiçado, com lenticelas elípticas, transversais; exterior da casca bege. Ramos quadrangulares ou cilíndricos, esparsamente pubescentes a glabros, com lenticelas. Estípulas elípticas a liguladas, obtusas, decíduas, estrigosas na face abaxial, 10-16×4-9 mm. Folhas com pecíolo 1-2,7 cm compr., estrigoso; lâmina elíptica a amplamente elíptica, $8,5-18 \times 6-11,7 \mathrm{~cm}$, glabra ou esparsamente pubescente na face adaxial, densamente estrigosa e esbranquiçada na face abaxial, ápice obtuso, às vezes curtamente acuminado, base obtusa a truncada; nervuras laterais 10-11 pares, impressas na face adaxial. Inflorescências tirsóides a paniculadas, piramidais, 3-5 cm compr.; ramos seríceos. Flores pequenas; cálice campanulado, seríceo, ca. $1 \times 1-1,5 \mathrm{~mm}$; corola amarela, densamente serícea externamente, internamente com tricomas alvos, 3-4 x1-1,5 mm; estames alvos. Drupas oblongas, 9-11 $\times 3-4 \mathrm{~mm}$.

Ocorre na região amazônica na Venezuela, Guianas, Brasil e possivelmente no Peru, e é muito semelhante a Malanea macrophylla Bartl. ex Griseb. (ver Taylor et al. 2004). De fato estes nomes foram sinonimizados por Boom \& Delprete (2002), porém, como os espécimes coletados na Reserva Ducke encaixam-se melhor dentro de M. hypoleuca conforme a circunscrição de Steyermark, este nome é utilizado aqui até que o gênero possa ser estudado de modo mais aprofundado. Na Reserva Ducke esta espécie foi coletada uma única vez na floresta de vertente, com flores em setembro (Campos \& Brito 1999: pág. 627, 629). 22.IX.1995 (fl) Vicentini \& Silva 1057 (INPA MO NY SPF).

21.3 Malanea sarmentosa Aubl., Hist. Pl. Guiane 1: 106, t. 41. $1775 . \quad$ Fig. 2k

Lianas lenhosas, ca. 4 cm diâm. Ramos acanalados. Ritidoma ferrugíneo ou marrom, com lenticelas orbiculares, espaçadas; casca internamente vermelho-ferrugínea ou bege, ca. $3 \mathrm{~mm}$ de espessura; alburno amarelo ou creme, depois de oxidado verde; exterior da casca marrom, ca. $1 \mathrm{~mm}$ de espessura. Estípulas elípticas a suborbiculares, decíduas, densamente hirsutas na face abaxial, 5-6 × 4-6 mm, arredondadas. Folhas com pecíolo $0,6-1,5 \mathrm{~cm}$ compr., hirsuto; lâmina amplamente elíptica a suborbicular, 5-9,5 × 4-7,6 cm, face adaxial glabra exceto pelas nervuras estrigosa, na face abaxial esbranquiçada e densamente velutina, ápice arredondado a truncado, base obtusa a subtruncada; nervuras laterais 6-8 pares, impressas na face adaxial. Inflorescências tirsóides a subcapitadas, 1,5-2,5 cm compr.; ramos hirsutos. Flores pequenas; cálice campanulado, seríceo, ca. $1 \mathrm{~mm}$ compr., denteado; corola amarelo-escura, densamente serícea ou hirsuta externamente, $4-5 \mathrm{~mm}$ compr. Drupas cilíndricas, $11-12 \times 4-5 \mathrm{~mm}$.

Ocorre no noroeste do América do Sul, Trinidad, Venezuela, Guianas, Brasil e 
possivelmente no Peru. Foi tratada por Campos \& Brito (1999: pág. 627, 629) sob “Malanea sp. 1". Na Reserva Ducke foi coletada na floresta de platô; floresce de junho a setembro. 28.VI.1996 (fl) Assunção et al. 323 (INPA MO SPF), 3.IX.1996 (fl) Campos \& Assunção 607 (INPA MO SPF).

Material adicional examinado: BRASIL. AMAZONAS: Manaus, BR 174, km 64, Fazenda Esteio, 18.XI.1986 (fl) Ackerly 117 (INPA K NY).

\section{Margaritopsis $\mathrm{C}$. Wright}

Arvoretas ou arbustos hermafroditas. Ramos cilíndricos, aplanados ou quadrangulares. Estípulas interpeciolares ou geralmente unidas ao redor do caule numa bainha, triangulares, aristadas ou bilobadas, persistentes ou decíduas às vezes por fragmentação. Folhas opostas, decussadas, subsésseis ou usualmente pecioladas. Inflorescências terminais, paniculadas a cimosas ou capitadas. Flores bissexuais, geralmente distílicas; cálice truncado a 5denteado; corola tubulosa ou infundibuliforme, alva ou amarela, de base estreita, glabra ou pubescente no interior, lobos 5, triangulares, prefloração valvar; estames 5, inseridos na porção mediana a superior do tubo da corola, anteras dorsifixas, inclusas ou exsertas; ovário 2-locular, óvulos 1 por lóculo; estigma 2-partido. Frutos drupáceos, carnosos, arroxeados ou alaranjados; pirênios 2, plano-convexos, costados ou lisos, cada um com uma semente.

Gênero pantropical com mais de 50 espécies, das quais cerca de 27 espécies são Neotropicais, ocorrendo no Caribe, México, América Central e América do Sul, atingindo a Bolívia e o Paraguai (Taylor 2005). Este gênero fazia parte de Psychotria (e.g., Campos \& Brito 1999), e pode ser reconhecido através de suas estípulas persistentes, flores pequenas, alvas a amarelas, em inflorescências terminais, e frutos drupáceos vermelhos. A distribuição espacial, habitat e riqueza local de várias espécies de Margaritopsis foram estudadas em detalhe por Kinupp (2002) and Kinupp \& Magnusson (2005).

\section{Chave para as espécies de Margaritopsis na Reserva Ducke}

1. Inflorescências cimosas, corimbiformes, 1,5-4 cm compr., com pedúnculos 1-3 cm compr... 1. M. boliviana

1'. Inflorescências capitadas ou subcapitadas, 4-10 mm compr., subsésseis.

2. Flores e frutos subsésseis ou curto-pedicelados; frutos ca. 4 mm diâm 3. M. nana

2'. Flores e frutos sésseis; frutos 5-11 mm diâm.

3. Cálice ca. $1 \mathrm{~mm}$ compr.; frutos 5-8 mm diâm. 2. M. cephalantha

3'. Cálice 2,5-5 mm compr.; frutos 8-11 mm diâm. 4. M. podocephala

22.1 Margaritopsis boliviana (Standl.) C.M. Taylor, Syst. Geogr. Pl. 75: 170. 2005. Fig. 2j

Psychotria boliviana Standl., Publ. Field Columbian Mus., Bot. Ser. 7: 302. 1931.

Árvores, arvoretas ou arbustos até 6 $\mathrm{m}$ alt., $6 \mathrm{~cm}$ diâm. Tronco circular, às vezes levemente tortuoso, com base reta. Ritidoma amarelo, marrom ou marrom-acinzentado, frágil, liso, com lenticelas; exterior da casca marrom, ca. $1 \mathrm{~mm}$ de espessura; casca internamente bege ou alaranjada, fibrosa, 2-3 $\mathrm{mm}$ de espessura; alburno amarelo, creme ou creme-amarelado; odoríferas. Ramos cilíndricos ou quadrangulares, glabros.
Estípulas glabras, 1-2 mm compr., truncadas ou arredondadas. Folhas opostas, pecioladas; pecíolo 3-10 mm compr.; lâmina elíptica ou elíptico-oblonga, $8-21 \times 2,8-8 \mathrm{~cm}$, ápice acuminado, base cuneada ou obtusa, papirácea, glabra; nervuras laterais 7-12 pares. Inflorescências corimbiformes, cimosas, glabras, pedúnculo 1-3 cm compr., panícula $1,5-4 \times 2,5-4 \mathrm{~cm}$, brácteas reduzidas. Flores subsésseis; cálice ca. $1 \mathrm{~mm}$ compr., subtruncado; corola infundibuliforme, alva, externamente glabra, vilosa na fauce, tubo ca. 2 mm compr., lobos 3-3,5 mm compr. Drupas elipsóides, $8-10 \times 8-10 \mathrm{~mm}$, alaranjadas ou 
vermelhas, passando a arroxeadas ou negras; pirênios com 3-5 costas longitudinais.

Esta espécie ocorre na Colômbia, Peru, Guianas, Venezuela, Bolívia e na amazônia brasileira. Previamente foi confundida $\operatorname{com} M$. astrellantha (Wernham) C.M. Taylor (sob o name de Psychotria astrellantha Wernham em Campos \& Brito 1999: pág. 629, 639), porém um estudo recente esclareceu a identidade dos espécimes coletados na Reserva Ducke (Taylor 2005). Kinupp (2002, fig. 5A) caracterizou esta espécie (sob o nome equivocado de "Psychotria astrellantha") como uma das espécies de mais comuns e amplamente distribuídas do grupo de Psychotria e gêneros afins dentro da reserva, e também registrou a presença de galhas nas folhas dos indivíduos. Na Reserva Ducke, foi coletada na floresta de platô, vertente e campinarana, com flores em agosto e com frutos de janeiro a maio, julho e dezembro. 9.I.1995 (fr) Assunção 126A (INPAMOSPF); 27.II.1996 (fr) Campos \& Pereira 526 (INPA K MO SPF), 5.III.1996 (fr) Campos \& Silva 535 (INPAK MO SPF), 3.V.1996 (fr) Hopkins et al. 1589 (INPAMO); 7.III.1996 (fr) Campos \& Silva 540 (INPA K MO SPF); $21 . I 11996$ (fr) Campos et al. 510 (INPA KMOSPF); 30.VIII.1994 (fl) Sothers 150 (INPA K MO SPF); 23.III.1995 (fr) Sothers \& Pereira 359 (INPAMO SPF); 25.I.1995 (fr) Nascimento \& Silva 717(INPA K MO SPF); 30.I.1996 (fr) Ribeiro et al. 1784 (INPA K MO SPF); 24.IV.1995 (fr) Sothers \& Silva 408 (INPAK MO SPF); 9.XII.1994 (fr) Sothers et al. 301 (INPA K MO); 11.III.1994 (fr) Ribeiro et al. 1228 (INPA K MO SPF); 5.VII.1993 (fr) Ribeiro et al. 1017 (INPA K MO SPF), 13.V.1997, Sothers \& Assunção 981 (INPA MO); 10.II.2000 (fr) Anunciação \& Pereira 805 (SP).

22.2 Margaritopsis cephalantha (Müll. Arg.) C.M. Taylor, Syst. Geogr. Pl. 75: 171. 2005. Psychotria cephalantha Müll. Arg., Flora 59: 495, 497. 1876.

Arbustos até $2 \mathrm{~m}$ alt., $3 \mathrm{~cm}$ diâm. Tronco circular, base reta. Ritidoma marrom com estrias longitudinais; exterior da casca marrom; casca internamente creme; alburno creme, odor fraco e agradável. Ramos cilíndricos ou quadrangulares, glabros. Estípulas glabras, 1-2 mm compr., truncadas ou arredondadas. Folhas opostas, pecioladas; pecíolo 5-18 mm compr.; lâmina elíptica, 6$22 \times 2,5-8 \mathrm{~cm}$, ápice acuminado, base cuneada ou obtusa, papirácea, glabra; nervuras laterais 9-12 pares. Inflorescências glabras, capitadas, subsésseis, 4-10 mm compr. Flores sésseis; cálice ca. $1 \mathrm{~mm}$ compr., truncado ou curto-denteado; corola infundibuliforme, alva, glabra externamente, fauce vilosa, tubo 3,5-4,5 $\mathrm{mm}$ compr., lobos 1,5-2 mm compr. Drupas elipsóides, 5-8 $\times$ 5-8 mm, vermelhas ou alaranjadas; pirênios com 3-5 costas longitudinais.

Ocorre na Colômbia, Peru, Guianas, Venezuela, Bolívia e na amazônia brasileira. Juntamente com $M$. nana (ver discussão abaixo), foi previamente confundida $\operatorname{com} M$. deinocalyx (Sandwith) C.M. Taylor (como Psychotria deinocalyx Sandwith, e.g., Campos \& Brito 1999: pág. 627, 647), mas um estudo recente do gênero esclareceu a identidade das plantas da Reserva (Taylor 2005). Em M. deinocalyx a parte livre, ou tubo, do cálice apresenta-se truncada a subtruncada e mais longa, atingindo $2-3 \mathrm{~mm}$ compr. Tanto M. cephalantha como M. nana apresentam tubo do cálice de $0,5-1 \mathrm{~mm}$ compr., claramente lobado ou denteado. $M$. cephalantha foi estudada por Kinupp (2005, fig. 6c), tendo sido coletada na floresta de platô e vertente, apenas com frutos em abril. 1.IV.1996 (fr) Campos \& Silva 587 (INPA MO SPF).

22.3 Margaritopsis nana (K. Krause) C.M. Taylor, Syst. Geogr. Pl. 75: 175. 2005.

Psychotria nana K. Krause, Verh. Bot. Vereins Prov. Brandenburg 50: 109. 1908.

Psychotria nudiceps Standl., Publ. Field Columbian Mus., Bot. Ser. 8: 378. 1931.

Arbustos até $1,5 \mathrm{~m}$ alt., $1 \mathrm{~cm}$ diâm. Tronco circular, base reta. Ritidoma marrom com estrias longitudinais; exterior da casca marrom; casca internamente creme; alburno creme; odor fraco e agradável. Ramos cilíndricos ou quadrangulares, glabros. Estípulas glabras, estreitamente triangulares, ca. $1 \mathrm{~mm}$ compr., aristadas, decíduas. Folhas opostas, pecioladas; pecíolo 1-8 mm compr.; 
lâmina elíptica, 5-14,5×2-6cm, ápice acuminado, base cuneada ou obtusa, papirácea, glabra; nervuras laterais 9-12 pares. Inflorescências glabras, subcapitadas ou cimosas, subsésseis, 4 $10 \mathrm{~mm}$ diâm. Flores subsésseis ou curtopediceladas; cálice ca. 0,5 mm compr., sinuoso ou curto-denteado; corola infundibuliforme, alva, externamente glabra, vilosa na fauce, tubo ca. 1,5 mm compr., lobos ca. 1,5 mm compr. Drupas elipsóides, ca. $4 \times 4 \mathrm{~mm}$, vermelhas ou alaranjadas; pirênios com 3-5 costas longitudinais.

Ocorre na Venezuela, Peru, Colômbia, Equador, Bolívia e na amazônia brasileira. Juntamente com $M$. cephalantha, esta espécie foi confundida com $M$. deinocalyx (Sandwith) C.M. Taylor (como Psychotria deinocalyx Sandwith em materiais examinados por Campos \& Brito (1999), porém estudos posteriores (Taylor 2005) ajudaram a elucidar a identidade destes espécimes, separando-os tanto de $M$. cephalantha, com base principalmente nas dimensões menores de suas estruturas reprodutivas, como de $M$. deinocalyx (ver discussão sob $M$. cephalantha). Na Reserva Ducke, $M$. nana foi coletada apenas com frutos, em fevereiro, março e agosto.

21.III.1995 (fr) Sothers et al. 349 (INPAMO); 8. II.1996 (fr) Campos et al. 467 (INPA MO); 14.VIII.1997, Assunção \& Pereira 617 (INPA MO); 28.IIII.1996 (fr) Campos \& Sothers 584 (INPA MO SPF).

22.4 Margaritopsis podocephala (Müll. Arg.) C.M. Taylor, Syst. Geogr. Pl. 75: 176. 2005. Mapouria podocephala Müll. Arg., Flora 59: 460, 466. 1876.

Psychotria podocephala (Müll. Arg.) Standl., Publ. Field Columbian Mus., Bot. Ser. 7: 109. 1930.

Árvores, arbustos ou arvoretas até 5 $\mathrm{m}$ alt. Ramos cilíndricos ou aplanados, glabros. Estípulas glabras, 3-10 mm compr., triangulares ou obovadas, obtusas, agudas ou 1-2-apiculadas. Folhas opostas, pecioladas; pecíolo 3-5 mm compr.; lâmina elíptica ou elíptico-oblonga, $12-27 \times 4,5-11 \mathrm{~cm}$, ápice agudo ou acuminado, base cuneada ou aguda, cartácea, glabra; nervuras laterais 9-11 pares. Inflorescências capitadas, subsésseis ou pedunculadas, pedúnculo 0-9 mm compr., glomérulo 12-18 mm diâm. Flores sésseis; cálice 2,5-5 mm compr., denteado; corola infundibuliforme, alva, glabra externamente, fauce vilosa, tubo ca. $5 \mathrm{~mm}$ compr., lobos ca. 2,5 mm compr. Drupas elipsóides, 10-15 $\times$ 8-11 mm, alaranjadas ou vermelhas; pirênios com 3-5 costas longitudinais arredondadas.

Ocorre no Peru, Venezuela e Brasil, na região amazônica. Estudada por Kinupp (2002: fig. 12d) como Psychotria podocephala, foi coletada na Reserva Ducke na floresta de vertente e platô, com flores em setembro e frutos de março a junho (Kinupp 2002). Campos \& Brito (1999: pág. 627, 639; sob Psychotria podocephala).

26.VI.2001 (fr) V.F. Kinupp 1923 (INPA); 26.IV.1994 (fr) Vicentini 503 (INPA SPF).

\section{Morinda L.}

Árvores, arvoretas ou arbustos hermafroditas, às vezes escandentes. Ramos cilíndricos ou quadrangulares. Estípulas interpeciolares ou unidas ao redor do caule, persistentes, triangulares ou bilobadas, de ápice cuspidado ou bipartido. Folhas opostas ou ternadas, subsésseis ou pecioladas, decussadas. Inflorescências terminais e/ou axilares, capitadas, glomérulos 1-muitos por inflorescência. Flores bissexuais, freqüentemente distílicas, livres ou fusionadas pelos ovários; cálice truncado ou sinuoso; corola infundibuliforme ou hipocrateriforme, alva, as vezes carnosa, glabra ou pubérula no interior da fauce, lobos 4-5(-7), prefloração valvar; estames 4-5(-7), inseridos no tubo ou na fauce, anteras dorsifixas, inclusas ou exsertas; ovário 2- ou 4-locular, óvulos 1 ou 2 por lóculo; estigma inteiro ou 2-partido. Frutos drupáceos, globosos ou elipsóides, livres ou fundidos num sincarpo, carnosos, negros ou esbranquiçados; pirênios 1-4, uniloculares; sementes oblongas, obovóides ou reniformes.

Gênero pantropical com cerca de 90 espécies, a maioria distribuída nos paleotrópicos, com cerca de 25 espécies neotropicais e uma distribuição ampla no Novo Mundo (Taylor et al. 2004). As características deste gênero são 
as inflorescências em glomérulos, as flores com hipantos geralmente fundidos uns aos outros, desenvolvendo-se, ao frutificar, num sincarpo carnoso. O gênero Appunia é caracterizado pela presença de flores e frutos livres, sendo que Taylor et al. (2004) consideram Appunia como sinônimo de Morinda.

23.1 Morinda triphylla (Ducke) Steyerm., Mem. New York Bot. Gard. 23: 386. 1972.

Fig. 21

Arvoretas ou arbustos, 1,5-3 m alt., ca. $2 \mathrm{~cm}$ diâm. Tronco circular, base reta. Ritidoma marrom, levemente fissurado, frágil, de desprendimento esfarelento; exterior da casca marrom, fina, ca. 0,5 mm de espessura; casca internamente creme, ca. $1 \mathrm{~mm}$ de espessura; alburno bege escuro, fibroso. Ramos quadrangulares, tomentosos, fistulosos. Estípulas interpeciolares, triangulares, bipartidas no ápice, 5-7×3-5 mm, tomentosas. Folhas opostas ou ternadas, curto-pecioladas; pecíolo 3-15 mm compr., pubescente; lâmina estreito-lanceolada a lanceolada ou elíptica, $10-24 \times 5-7,3 \mathrm{~cm}$, ápice acuminado, base cuneada, pubérula a pilosa em ambas as faces; nervuras laterais 11-12 pares. Inflorescências axilares, sésseis, glomérulos 1-2 cm compr. Flores sésseis, livres; cálice truncado ou curtamente 4-5-denteado, ca. $2 \times 2 \mathrm{~mm}$; corola creme-esverdeada, face externa tomentosa, 1,4-2 × 1-2 mm, lobos 4-5, com apêndices lineares, 0,5-1 mm compr.; estames 4-5, sésseis, anteras oblongas, estigma 2-partido. Drupas avermelhadas, elipsóides, 8-12×4$5 \mathrm{~mm}$, glabras.

Ocorre no Brasil, nos estados do Amazonas e Pará. Na Reserva Ducke ocorre preferencialmente em áreas perturbadas como capoeiras e clareiras, podendo ocorrer ocasionalmente em floresta de platô. Foi coletada com flores e frutos em março e novembro, e apenas com flores em abril (Campos \& Brito 1999: pág. 634, 647).

21.III.1996 (fl fr) Campos et al. 573 (INPA MO NY SPF); XI.1972 (fl fr) Silva \& Rodrigues 1051 (INPA NY US); 2.IV.1971 (fl) Prance et al. 11281 (INPANY).
Material adicional examinado: BRASIL. PARÁ: via férrea Belém-Bragança, Peixe Boi, 21.III.1927 (fl) Ducke 23210 (IAN K RB - material-tipo de M. triphylla).

\section{Pagamea Aubl.}

Arbustos ou arvoretas hermafroditas. Ramos cilíndricos. Estípulas unidas numa bainha cilíndrica com 4-8 setas decíduas no ápice. Folhas opostas, pecioladas, decussadas. Inflorescências axilares ou às vezes "pseudoterminais" (quando dois ou mais ramos encontram-se inseridos lateralmente em relação à gema apical do ramo), 1-multifloras, espiciformes, cimosas, tirsóides ou paniculadas. Flores bissexuais, homostílicas ou distílicas; cálice cupular, truncado ou 4-6-denteado; corola rotácea ou campanulada, alva ou creme-esverdeada, 4(-5)-lobada, densamente pubescente internamente, prefloração valvar; estames 4 (5), exsertos, inseridos na região da fauce, anteras basifixas; ovário súpero, bilocular, óvulos 1 por lóculo; estigma inteiro. Frutos drupáceos, elipsóides a subglobosos, súperos, carnosos, negros ou atrovioláceos, envolvidos pelo cálice cupular persistente; pirênios 2, plano-convexos, unisseminados.

Gênero com cerca de 40 espécies, a maioria da região norte da América do Sul, particularmente Venezuela, Guianas, Brasil, Colômbia e Peru (Taylor et al. 2004). As estípulas unidas numa bainha terminal, apicalmente setosas e decíduas, o ovário súpero (raro na família) e os frutos cupulados semelhantes aos de Lauraceae caracterizam este gênero.

24.1 Pagamea macrophylla Spruce ex Benth., J. Linn. Soc., Bot. 1: 110. $1857 . \quad$ Fig. 3a

Arvoretas ou árvores, 6-10 m alt., 6$10 \mathrm{~cm}$ diâm. Tronco circular, algumas vezes nodoso, base reta ou levemente digitada. Ritidoma bege-acinzentado ou marromavermelhado, finamente estriado, escamoso; exterior da casca marrom, fibrosa, fina, ca. 0,5 $\mathrm{mm}$ de espessura; casca internamente rosada, 1-2 mm espessura; alburno creme a amarelado, odor suave. Ramos cilíndricos, glabros a esparsamente pubescentes. Estípulas 4,2-7,5 $\times 0,4 \mathrm{~mm}$, glabras, setas $1-2 \mathrm{~mm}$ compr. Folhas 
com pecíolo 1,1-2,7 cm compr., glabro; lâmina lanceolada a elíptica, 11-22 ×5,9-7,5 cm, ápice acuminado, base atenuada, glabra em ambas as faces; nervuras laterais 5-8 pares, impressas na face adaxial. Inflorescências racemosas, 8-10 cm compr., com pequenos grupos de 2-5 flores sésseis distribuídos ao longo dos eixos. Flores sésseis; cálice truncado a curto-denteado; corola verde-amarelada, rotácea, 5-6 mm compr., glabra externamente, lobos densamente pilosos, tricomas alvos. Drupas negras, globosas, 1,5$2,1 \times 0,8-0,15 \mathrm{~cm}$, glabras, cúpula do cálice amarelada ou avermelhada.

Apresenta distribuição conhecida apenas para o Norte do Brasil mas é provavel que ocorra também na Colômbia. Na Reserva Ducke foi observada em todos os ambientes, florescendo de fevereiro a agosto e frutificando de fevereiro a junho (Campos \& Brito 1999: pág. 626, 646, 647).

12.V.1994 (fr) Vicentini et al. 539 (INPA MO NY SPF); 16.VI.1994 (fl) Ramos \& Silva 2842 (INPA K MO NY SPF); 4.VI.1993, Ribeiro et al. 841, 1841 (INPA K MO NY SPF); 3.II.1995 (fr) Vicentini et al. 839 (INPA K MO NY SPF); 28.IV.1995 (fr) Ribeiro et al. 1616 (INPA K MO NY SPF); 26.IV.1996 (fl) Ribeiro et al. 1821 (INPA K MO SPF); 13.III.1996 (fr) Campos \& Silva 546 (INPA K MO SPF); 31.VIII.1966 (fl) Prance et al. 2130 (INPA K NY).

\section{Palicourea Aubl.}

Arvoretas ou árvores hermafroditas. Ramos cilíndricos, triangulares ou quadrangulares; madeira tipicamente quebradiça. Estípulas unidas ao redor do caule numa bainha, geralmente bilobadas de cada lado, persistentes. Folhas opostas ou 3-4-verticiladas, decussadas, subsésseis ou pecioladas. Inflorescências terminais, paniculadas ou cimosas, geralmente coloridas. Flores bissexuais, geralmente distílicas; cálice subtruncado ou 5-lobado; corola tubular ou infundibuliforme, frequentemente colorida, gibosa na base, internamente glabra exceto por um anel piloso acima da base gibosa, 5-lobada, prefloração valvar; estames 5, inseridos na porção mediana a superior do tubo da corola, anteras dorsifixas, inclusas ou exsertas; ovário 2(-5)-locular, óvulos 1 por lóculo; estigma 2(-5)-partido. Infrutescências geralmente coloridas. Frutos drupáceos, elipsóides ou subglobosos, carnosos, arroxeados, azuis ou negros; pirênios 2, plano-convexos, geralmente costados, unisseminados.

Gênero neotropical com cerca de 200 espécies, do México, Caribe, América Central e principalmente na América do Sul (Taylor 1997), assemelha-se a Psychotria subg. Heteropsychotria, do qual se distingue pela corola estreita (não gibosa) na base, podendo ser pilosa internamente mas, neste caso, nunca apresentando um anel de tricomas abaixo do terço inferior do tubo. Palicourea é frequentemente confundida com Isertia; em Isertia as estípulas são intrapeciolares ou profundamente lobadas e aparentemente livres, as anteras são loceladas, e os pirênios são multisseminados.

\section{Chave para as espécies de Palicourea na Reserva Ducke}

1. Folhas (3)4-verticiladas; estípulas com a porção interpeciolar truncada ou largamente triangular, e às vezes bilobada, com lobos lineares; pirênios lisos.

2. Brácteas florais $4-11 \mathrm{~mm}$ compr.; frutos com 2 pirênios 3. P. corymbifera

2'. Brácteas florais 1,2-2 mm compr.; frutos com 5 pirênios 8. P. virens

1'. Folhas opostas; estípulas com a porção interpeciolar truncada ou em forma de U, bilobadas, lobos arredondados, ligulados ou triangulares; pirênios com 3-5 sulcos longitudinais.

3. Inflorescências piramidais ou cilíndricas, mais longas do que largas, com perfil triangular, com 6 ou mais pares de ramos secundários desenvolvidos.

4. Inflorescências cilíndricas, vermelhas ou róseas, 1,5-3 cm larg.; corolas vermelhas, violetas ou rosadas; frutos secos elipsóides, lateralmente achatados, pirênios com 35 cristas longitudinais agudas separadas por sulcos largos, côncavos

2. P. anisoloba 

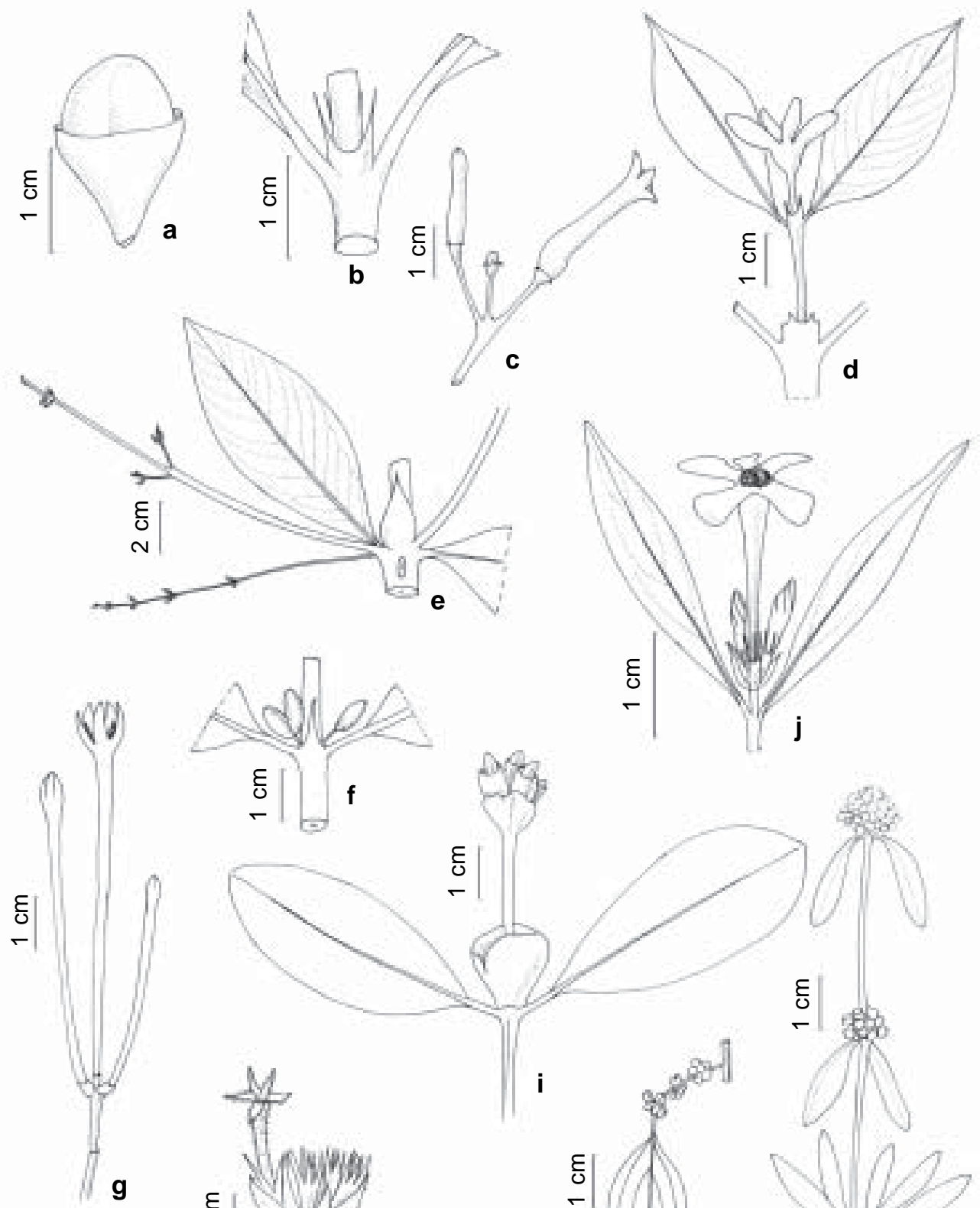

g
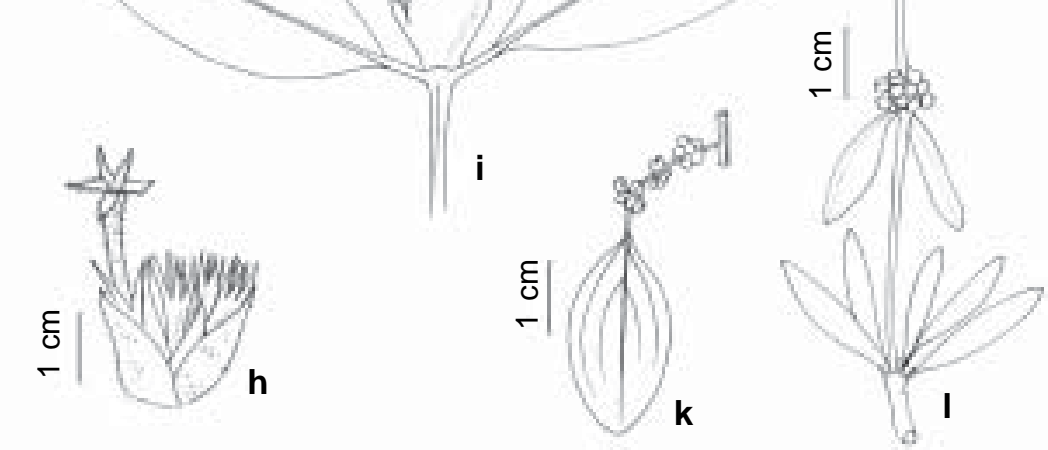

Figura 3 - a. Pagamea macrophylla, fruto (Ribeiro 841); b. Palicourea longistipulata, detalhe do ramo mostrando estípula bilobada (Nascimento 633); c. Palicoura longiflora, detalhe da inflorescência (Nascimento 634); d. Psychotria turbinella, ramo mostrando inflorescência involucrada e estípulas bilobadas (Pacheco 109); e. Remijia amazonica, detalhe da estípula e das inflorescências laterais (Ducke 194); f. Ronabea latifolia, detalhe do ramo mostrando estípula e frutos laterais (Campos 478); g. Rudgea gracilliflora, detalhe da inflorescência (Assunção 393); h. Sabicea amazonensis, detalhe da inflorescência bracteada (Costa 207); i. Schradera polycephala, parte apical do ramo mostrando estípulas e infrutescência (Campos 502); j. Sipanea pratensis, parte apical do ramo mostrando inflorescência (Costa 43); k. Spermacoce verticillata, parte apical do ramo mostrando estípulas e inflorescências (Costa 56); 1. Warszewiczia schwackei, detalhe da infrutescência com bráctea corolina (Ducke 24380). 
4'. Inflorescências piramidais, alaranjadas ou avermelhadas, 7,5-13 cm larg.; corolas amarelas; frutos secos ovóides ou subglobosos, pirênios com 3-5 cristas longitudinais arredondadas separadas por sulcos estreitos 4. P. guianensis

3'. Inflorescências corimbiformes, mais largas do que longas, com perfil arredondado até plano no ápice, com 1-4 pares de ramos secundários desenvolvidos.

5. Flores subsésseis em cimeiras congestas, cada uma acompanhada por 1-3 brácteas de 1-7 mm compr., elípticas ou lanceoladas 6. $P$. longistipulata

5'. Flores pediceladas em cimeiras abertas, ebracteadas ou os pedicelos acompanhados por 1-2 brácteas ou bractéolas de $0,3-1 \mathrm{~mm}$ compr., triangulares.

6. Corolas 9-16 mm compr., tubo densamente tomentoso externamente, lobos glabros nigrescentes no material seco 7. P. nitidella

6'. Corolas 14-23 mm compr., tubo glabro a pubérulo externamente, lobos não distintos do restante da corola no material seco.

7. Corolas purpúreas ou violetas; frutos secos $9-11 \times 8-10 \mathrm{~mm}$..... 1. P. amapaensis

7'. Corolas amarelas na base passando a rosas ou purpúreas nos lobos; frutos secos $4-5 \times 5-6 \mathrm{~mm}$ 5. P. longiflora

25.1 Palicourea amapaensis Steyerm., Mem. New York Bot. Gard. 23: 765. 1972.

Arvoretas ou arbustos até $10 \mathrm{~m}$ alt., 5 $\mathrm{cm}$ diâm. Tronco circular de base reta. Ritidoma marrom, estriado, com anéis transversais; exterior da casca marrom-esverdeada; casca internamente bege, ca. $3 \mathrm{~mm}$ de espessura; alburno cremealaranjado. Ramos cilíndricos ou quadrangulares, glabros. Estípulas glabras, bainha 0,5-1 mm compr., lobos arredondados, 0,5-1,5 mm compr. Folhas opostas, pecioladas; pecíolo 1-2 cm compr.; lâmina elíptica ou lanceolada, 13-16 $\times 4-11.5 \mathrm{~cm}$, ápice acuminado, base cuneada ou obtusa, papirácea, glabra; nervuras laterais 7-11 pares, planas na face adaxial, salientes na face abaxial. Inflorescências corimbiformes, rosa intenso, 3,5-4,6 $6-8 \mathrm{~cm}$, pedúnculo 3-4 cm compr., brácteas florais $0,3-$ $0,5 \mathrm{~mm}$ compr. Flores com cálice $0,3-0,4 \mathrm{~mm}$ compr., truncado ou curto-denteado; corola purpórea ou violeta, de coloração uniforme, glabra externamente, tubo 2,2-2,3 cm compr., 2-3 mm diâm. na porção mediana, lobos 2-4 mm compr. Drupas elipsóides, $0,9-1,1 \times 0,8-$ $1 \mathrm{~cm}$; pirênios com 3-5 sulcos longitudinais.

Ocorre na Guiana Francesa e no Brasil, nos estados do Amazonas e Amapá. Na Reserva, foi coletada na floresta de platô, apenas com flores, em setembro e outubro (Campos \& Brito 1999: pág. 638).
11.X.1994 (fl) Vicentini et al. 725 (INPA MO NY SPF), 28.IX.1994 (fl) Sothers et al. 184 (INPA MO NY SPF); 2.IX.1996 (fl) Campos \& Assunção 605 (INPA MO SPF).

25.2 Palicourea anisoloba (Müll. Arg.) B. Boom \& M.T. Campos, Bol. Mus. Par. Emílio Goeldi, Sér. Bot. 7(2): 243. 1991.

Psychotria anisoloba Müll. Arg., Fl. bras. 6(5): 237. 1881.

Palicourea duckei Standley, Publ. Field Mus. Nat. Hist., Bot. Ser. 22: 195. 1940.

Árvores, arvoretas ou arbustos até 8 $\mathrm{m}$ alt., $4 \mathrm{~cm}$ diâm. Ritidoma marrom, estriada; exterior da casca marrom, menos de $1 \mathrm{~mm}$ espessura; casca internamente creme com estrias alaranjadas, ca. $2 \mathrm{~mm}$ espessura; alburno bege. Ramos cilíndricos ou quadrangulares, glabros. Estípulas glabras, bainha $0,5-1 \mathrm{~mm}$ compr., lobos agudos, 2-4 mm compr. Folhas opostas, pecioladas; pecíolo 5-20 mm compr.; lâmina elíptica, 7$30 \times 2,5-11,5 \mathrm{~cm}$, ápice acuminado, base aguda, cuneada ou obtusa, papirácea, glabra ou pubérula na face abaxial; nervuras laterais 9-20 pares, planas na face adaxial, salientes na face abaxial. Inflorescências cilíndricas, vermelho-arroxeadas ou rosa-fortes, 6-17 $\times$ $1,5-4 \mathrm{~cm}$, pedúnculo $4-11,5 \mathrm{~cm}$ compr., brácteas florais 0,5-1 mm compr. Flores com 
cálice $0,3-0,8 \mathrm{~mm}$ compr., truncado ou curtolobado, vermelho ou rosa-amarelado; corola vermelha, violeta ou rosa, pubérula ou pilosa externamente, tubo 1,8-2 cm compr., 2-3 mm diâm. na porção mediana, lobos $1,5-2 \mathrm{~mm}$ compr. Drupas elipsóides, ca. $7 \times 5 \mathrm{~mm}$; pirênios com 3-5 com sulcos longitudinais.

Ocorre somente no Brasil, na região de Manaus. Na Reserva, foi coletada na floresta de baixio e vertente, com flores de julho a outubro, com frutos de fevereiro a abril (Campos \& Brito 1999: pág. 625, 626, 638).

11.VII.1994 (fl) Vicentini \& Assunção 594 (INPA MO); 7.VIII.1994 (fl) Vicentini et al. 661 (INPA MO); 2.IX.1996 (fl) Campos \& Silva 600 (INPA MO); 21.IX.1994 (fl) Ribeiro \& Silva 1429 (INPA MO); 19.X.1994 (fl) Costa et al. 15 (INPA MO); 26.X.1995 (fl) Ribeiro 1752 (INPA MO); $10 . I I .1996$ (fr) Campos et al. 477 (INPA MO); 6.III.1988 (fr) Santos \& Lima 848 p.p. (INPA MO SPF); 7.IV.1988 (fr) Santos \& Lima 878 (INPA K MO); 7.X.1966 (fl) Prance et al. 2621 (INPA K NY).

25.3 Palicourea corymbifera (Müll. Arg.) Standl., Publ. Field Columbian Mus., Bot. Ser. 7: 127.1930.

Arvoretas ou arbustos até $7 \mathrm{~m}$ alt., $7 \mathrm{~cm}$ diâm. Tronco circular, com anéis transversais proeminentes e lenticelas circulares em pequena quantidade. Ritidoma marrom, liso, com estrias longitudinais; exterior da casca marrom-esverdeada ou verde; casca internamente creme, fibrosa; alburno creme; odor suave. Ramos cilíndricos ou angulares, fistulosos, glabros ou pubérulos. Estípulas glabras ou pubérulas, bainha $2-6 \mathrm{~mm}$ compr., truncada ou largamente triangular, lobos lineares, 0,5-1 compr. Folhas 4-verticiladas, pecioladas; pecíolo 3-15 mm compr.; lâmina elíptica, 10-35 × 3-9 cm, ápice acuminado, base cuneada ou aguda, papirácea, glabra ou pubérula; nervuras laterais 11-28 pares, planas na face adaxial, salientes na face abaxial. Inflorescências corimbiformes, alaranjadas ou amareladas, 4,5-9 × 6-12 cm, pedúnculo 4-11,5 cm compr., brácteas florais 4-11 mm compr. Flores com cálice 0,2-0,3 mm compr., denteado ou subtruncado; corola amarela, acastanhada ou rosada, densamente hirtela ou glabrescente externamente, tubo 8-12 mm compr., 2,5-3 mm diâm. na porção mediana, lobos 1-2 mm compr. Drupas elipsóides, ca. $3 \times 5 \mathrm{~mm}$; pirênios lisos.

Ocorre na Guiana Francesa, Venezuela e Brasil, na região amazônica. Na Reserva, foi coletada na floresta de platô e vertente, com flores de setembro a dezembro e com frutos de dezembro a março (Campos \& Brito 1999: pág. 626, 633, 647).

14.IX.1987 (fl) Pruski et al. 3240 (INPA); 17.IX.1987 (fl) Pruski et al. 3280 (INPA); 2. IX1996 (fl) Campos \& Silva 601 (INPA MO); 22.III.1996 (fr) Campos et al. 579 (INPA K MO NY); 1.IX.1996 (fl) Prance et al. 2147 (MO NY W); 2.IX.1997, Costa \& Pereira 769 (INPA MO); 12.XII.1996 (fl) Assunção et al. 437 (INPA K MO); 11.X.1996 (fl) Sothers et al. 912 (MO); $12 . X I I .1996$ (fr) Sothers et al. 953 (INPA K MO); 1.IX.1966 (fl) Prance et al. 2147 (INPA K NY).

25.4 Palicourea guianensis Aubl., Hist. Pl. Guiane 1: 173, t. 66. 1775.

Arvoretas ou árvores até $8 \mathrm{~m}$ alt., 5 cm diâm. Tronco circular, base reta. Ritidoma com exterior da casca marrom-escuro ou marrom-claro, levemente fissurado; casca internamente bege, fibrosa; alburno creme ou branco; odor agradável. Ramos cilíndricos ou quadrangulares, glabros ou pubérulos. Estípulas glabras ou pubérulas, bainha 1-5 mm compr., lobos arredondados, 3-8 mm compr. Folhas opostas, pecioladas; pecíolo 0,8-3 cm compr.; lâmina elíptica ou ovada, 18-35 ×7$17 \mathrm{~cm}$, ápice acuminado, base cuneada ou obtusa, papirácea, glabra ou pubérula; nervuras laterais 18-19 pares, planas ou salientes na face adaxial, salientes na face abaxial. Inflorescências piramidais, amarelas, 8-15 $\times 7-15 \mathrm{~cm}$, pedúnculo 6-12 cm compr., brácteas florais $0,5-1,0 \mathrm{~mm}$ compr. Flores com cálice 0,3-0,8 mm compr., curto-denteado; corola amarela, externamente pubérula, tubo 9-25 mm compr., 1,5-2,5 mm diâm. na porção mediana, lobos 1,5-2 mm compr. Drupas ovóides, 4-7 × 3,5-5 mm; pirênios com 3-5 sulcos longitudinais. 
Apresenta ampla distribuição, ocorrendo no México, Caribe, Bolívia e no Brasil. Na Reserva, foi coletada em todos os ambientes, com flores de outubro a novembro, com frutos fevereiro, março e julho (Campos \& Brito 1999: pág. 626, 638).

24.X.1994 (fl) Sothers 237 (INPA); 22.III.1994 (fr) Vicentini et al. 432 (INPA K MO SPF); 8.XI.1994 (fl) Nascimento \& Silva 628 (INPA K MO SPF); 26.II.1996 (fr) Campos \& Pereira 522 (INPA K MO NY SPF); 5.VII.1993 (fr) Ribeiro et al. 1029 (INPA KMO NY SPF); 10.X.1966(fl.), Assunção 414 (INPA K SPF); 6.III.1988 (fr) Santos \& Lima 848 p.p. (INPA K NY); 7.II.2000 (fr) Anunciação \& Pereira 785 (INPA SP SPF).

25.5 Palicourea longiflora DC., Prodr. 4: 528. 1830.

Fig. 3c

Arvoretas ou arbustos até $4 \mathrm{~m}$ alt., 3 cm diâm. Ramos cilíndricos ou quadrangulares, glabros ou pubérulos. Estípulas glabras ou pubérulas, bainha 0,5-1 mm compr., lobos agudos, 0,5-0,8 mm compr. Folhas opostas, pecioladas; pecíolo 3-11 mm compr.; lâmina elíptica ou ovada, 6-20 ×3,5-8 cm, ápice agudo ou acuminado, base cuneada ou obtusa, papirácea, glabra ou pubérula, na face abaxial algumas vezes arroxeada; nervuras laterais 713 pares, planas na face adaxial, salientes na face abaxial. Inflorescências corimbiformes, alaranjadas ou amareladas, 3-6 × 4-8 cm, pedúnculo 4-8,5 cm compr., brácteas florais 0,5-2 mm compr. Flores com cálice 0,2-0,5 mm compr., truncado ou curto-denteado; corola com tubo amarelo e lobos violáceos ou arroxeados, externamente pubérula, tubo 23$28 \mathrm{~mm}$ compr., 1,5-3 mm diâm. na porção mediana, lobos 2-3 mm compr. Drupas ovóides, 4-5 × 5-6 mm; pirênios com 3-5 sulcos longitudinais.

O homônimo Palicourea longiflora (Aubl.) Rich. (Mém. Rubiaceae 95, t. 9, f. 2. 1829 [publ. dez. 1930]) foi publicado após o nome de De Candolle, que data de setembro de 1930, e que tem prioridade sobre o nome publicado por Richard (Taylor et al. 2004).

Esta espécie ocorre na Guiana Francesa, Suriname, Venezuela e Brasil, nos estados da região amazônica. Na Reserva, foi coletada na floresta de vertente, com flores em março e novembro, com frutos em fevereiro e março (Campos \& Brito 1999: pág. 626, 636).

10.XI.1994 (fl) Nascimento \& Silva 634 (INPA K MO NY SPF); 5.III.1996 (fr) Campos \& Silva 532 (INPA MO SPF); 8.II.1996 (fr) Campos et al. 460 (INPA MO); 23.XI.1995 (fl) Ribeiro et al. 1769 (INPA K MO SPF); 1.XI.1991 (fl) J. Ramos \& J. Guedes 1743 (NY); 25.III.2000 (fr) Anunciação \& Pereira 862 (INPA SP).

25.6 Palicourea longistipulata (Müll. Arg.) Standl. subsp. longistipulata Publ. Field Columbian Mus., Bot. Ser. 7: 140. 1930.

Arvoretas ou arbustos até $5 \mathrm{~m}$ alt., ca. $4 \mathrm{~cm}$ diâm. Tronco cilíndrico, base reta. Ritidoma marrom-acizentado, liso, rígido, desprendimento pulverulento; exterior da casca marrom-acinzentada; casca internamente bege ou amarela, fibrosa; alburno bege ou branco. Ramos cilíndricos ou quadrangulares, pilosos. Estípulas pilosas, bainha 2-4,5 mm compr., lobos agudos, 3-26 $\mathrm{mm}$ compr. Folhas opostas, pecioladas; pecíolo 4-20 mm compr.; lâmina elíptica, 12$40 \times 3,5-15 \mathrm{~cm}$, ápice agudo ou acuminado, base cuneada ou aguda, papirácea, pilosa; nervuras laterais 11-17 pares, planas na face adaxial, salientes na face abaxial. Inflorescências corimbiformes, vermelhas ou vermelho-alaranjadas, $2-7,5 \times 3-13 \mathrm{~cm}$, pedúnculo 1,5-10 $\mathrm{cm}$ compr., címulas acompanhadas por 1-3 brácteas florais de 1$7 \mathrm{~mm}$ compr. Flores com cálice 1-1,3 mm compr., curto-denteado; corola vermelhoamarelada, vinácea ou vermelha, externamente densamente pilosa, tubo 8-12 mm compr., 1,52,5 mm diâm. na porção mediana, lobos $1-1,5$ mm compr. Drupas ovóides, 4-5 × 3-4 mm; pirênios com 3-5 sulcos longitudinais. Fig. 3B.

Esta espécie ocorre nas Guianas, Colômbia, Venezuela, Peru, Bolívia e Brasil, da região amazônica até o Norte do Mato Grosso. Na Reserva, foi coletada em todos os ambientes, com flores em novembro, com frutos em janeiro, fevereiro e junho (Campos \& Brito 1999: pág. 626, 634). 
15.II.1996 (fr) Campos et al. 497 (INPA); 1.XI.1994 (fl) Ribeiro et al. 1463 (INPA NY), 1.XI.1994 (fl) Ribeiro et al. 1471 (INPANY); 3.VI.1993 (fr) Ribeiro et al. 815 (INPA MO NY SPF); 18.I.1996 (fr) Pirani et al. 3654 (INPA MO); 10.XI.1994 (fl) Nascimento \& Silva 633 (INPA K MO NY SPF); 25.XI.1994 (fl) Assunção 96 (INPA K MO NY SPF).

25.7 Palicourea nitidella (Müll. Arg.) Standl., Publ. Field Columbian Mus., Bot. Ser. 7: 142. 1930.

Palicourea lanata (Müll. Arg.) Standl., Publ. Field Columbian Mus., Bot. Ser. 8: 381. 1931.

Arvoretas ou arbustos até $2 \mathrm{~m}$ alt. Ramos cilíndricos ou quadrangulares, glabros, às vezes fistulosos. Estípulas glabras, bainha 1-1,5 mm compr., lobos agudos, 2-7 mm compr. Folhas opostas, pecioladas; pecíolo 5-30 mm compr.; lâmina elíptica ou ovada, 10-31 ×3,5-12 cm, ápice agudo ou acuminado, base cuneada ou aguda, papirácea, glabra ou pubérula; nervuras laterais 12-17 pares, salientes em ambas as faces. Inflorescências corimbiformes, vermelhas, 25,5 × 3-8 cm, pedúnculo 5-11,5 cm compr., brácteas florais 0,3-0,5 mm compr. Flores com cálice 0,5-1 mm compr., curto-denteado; corola vermelha ou róseo-avermelhada às vezes com lobos brancos ou amarelos, tubo 11-14 mm compr., externamente denso-pubescente, 2-4 mm diâm. na porção mediana, lobos $1,5-2 \mathrm{~mm}$ compr., glabros, nigrescentes no material seco. Drupas elipsóides ou subovóides, $4 \times 4-4,5 \mathrm{~mm}$; pirênios com 3-5 sulcos longitudinais.

Ocorre na Venezuela, Colômbia, Peru e Brasil, nos estados da região amazônica. $\mathrm{Na}$ Reserva, foi coletada em baixios, capoeiras e campinaranas, apenas com flores, em agosto e de outubro a dezembro (Campos \& Brito 1999: pág. 626, 638).

1.XI.1994 (fl) Ribeiro et al. 1470 (INPA); 8.VIII.1995 (fl) Souza et al. 67 (INPAMO SPF); 9.XII.1994, Costa \& Nascimento 44 (INPA K MO SPF); 12.X.1995 (fl) Ribeiro et al. 1726 (INPA MO NY SPF); 8.VI.1995 (fl) Soares 212 (INPA MO); 26.XI.1977, Keel \& Balick 197 (NY), 200 (NY); 6.II.1998, Brito \& Assunção 54 (INPA K MO); 8.VIII.1995 (fl.) Souza et al. 67 (INPA NY); Prance 2160 (INPA NY); 17.XI.1999 (fl) André 3186 (INPA SPF).
25.8 Palicourea virens (Poepp. \& Endl.) Standl., Field Mus. Nat. Hist., Bot. Ser. 11: 236. 1936.

Arvoretas ou arbustos até $4 \mathrm{~m}$ alt., ca. $3 \mathrm{~cm}$ diâm. Troncos com anéis transversais e lenticelas em pequena quantidade. Ramos cilíndricos ou angulares, glabros. Estípulas glabras, bainha 2-5 mm compr., truncada ou largamente triangular, lobos ( "aristas" em Campos \& Brito, 1999) lineares, 1-2 mm compr. Folhas (3)4-verticiladas, pecioladas; pecíolo 2-11 mm compr.; lâmina elíptica, 14$42 \times 3,5-12 \mathrm{~cm}$, ápice acuminado, base aguda, papirácea, glabra; nervuras laterais 12-22 pares, planas ou ligeiramente impressas na face adaxial, salientes na face abaxial. Inflorescências corimbiformes, amareladas ou amarelo-ouro, 2,5-8 $\times 3-12 \mathrm{~cm}$, pedúnculo 6-8 cm compr., brácteas florais $1,2-2 \mathrm{~mm}$ compr. Flores com cálice ca. 0,3 mm compr., curto-denteado ou subtruncado; corola amarela, externamente glabrescente, tubo 12$25 \mathrm{~mm}$ compr., 2,5-3 mm diâm. na porção mediana, lobos 2,5-3 mm compr. Drupas elipsóides, ca. $3 \times 5 \mathrm{~mm}$; pirênios 5 , lisos.

Esta espécie ocorre no Brasil, nos estados do Pará e Amazônas. Na Reserva, foi coletada na floresta de platô e vertente, com flores em julho e agosto, com frutos em fevereiro e outubro. Segundo Campos \& Brito (1999: pág. 626, 632) as folhas jovens desta espécie apresentam coloração arroxeada.

7.VII.1993 (fl) Ribeiro et al. 1054 (INPA NY); 13.X.1994 (fr) Vicentini et al. 751 (INPA NY); 22.VIII.1996 (fl) Costa \& Silva 562 (INPAMO SPF); 30.VII.1996 (fl) Azevedo et al. 7947 (INPA MO); 9.II.1996 (fr) Campos et al. 470 (INPA MO NY); 11.VII.1994 (fl) Vicentini \& Assunção 591 (INPAMO NY); 9.IX.1961, Rodriguez \& Coelho 3228 (NY).

\section{Posoqueria Aubl.}

Árvores, arvoretas ou arbustos hermafroditas. Ramos cilíndricos, geralmente espessados. Estípulas interpeciolares, triangulares ou ovadas, persistentes ou decíduas. Folhas opostas, decussadas, pecioladas, geralmente bem desenvolvidas e subcoriáceas. Inflorescências terminais, corimbosas ou 
umbeladas. Flores bissexuais, homostílicas, noturnas, vistosas; cálice 5-denteado; corola longamente salverforme, alva ou cremeamarelada, de tubo prolongado, internamente glabro ou papiloso, 5-lobada, prefloração imbricada; estames 5, iguais ou pouco desiguais, inseridos na região da fauce da corola, anteras basifixas, exsertas; ovário 2-locular ou incompletamente 1-locular, óvulos muitos por lóculo; estigma 1-partido. Frutos bacáceos, globosos a ovóides, lenhosos ou coriáceos, geralmente bem desenvolvidos, pardos ou alaranjados; sementes numerosas, angulosas ou subglobosas, imersas numa polpa gelatinosa.

Gênero com cerca de 20 espécies no México, Caribe, América Central e América do Sul tropical (Taylor et al. 2004). Pode ser diferenciado pelas folhas e estípulas conspícuas e geralmente coriáceas, flores alvas com o tubo bem desenvolvido e estreito, e fruto globoso, bem desenvolvido, com muitas sementes imersas numa polpa gelatinosa. Posoqueria é freqüentemente confundido com Tocoyena, mas distingue-se por apresentar o ápice do botão floral às vezes recurvado (não reto), a prefloração imbricada (não contorta), estames às vezes assimétricos, e sementes angulosas ou subglobosas (não comprimidas). As flores alvas são odoríferas principalmente durante a noite, e são provavelmente polinizadas por mariposas.

\subsection{Posoqueria sp.}

Árvores até $8 \mathrm{~m}$ alt. Ritidoma marrom; casca internamente marrom-avermelhada. Ramos cilíndricos, estriados, glabros e fistulosos. Estípulas 1,8-2 × 0,4-0,5 cm, glabras. Folhas com pecíolo $1,6-2,8 \mathrm{~cm}$ compr., glabro; lâmina ovada, largo-elíptica a largo-lanceolada, 28-30 × 14-17 cm, ápice agudo a curto-acuminado, base obtusa, margem revoluta, coriácea, glabra na face adaxial, hírtula na face abaxial; nervuras laterais 8-10 pares, nervação finamente saliente na face abaxial. Inflorescências e flores não vistas. Bagas globosas, bem desenvolvidas, glabras, 7-8 × 7-8 cm; sementes tetragonais, 9-17 $\times 11-17 \mathrm{~mm}$.
A identificação ao nível específico destes espécimes não foi possível devido à ausência de flores no material coletado, mas é provavel que se trate de Posoqueria latifolia (Rudge) Roem. \& Schult. ou de P. maxima Standl. Na Reserva, estes espécimes foi coletada na floresta de platô, com frutos em julho e agosto. Campos \& Brito (1999: pág. 642).

12.VIII.1993 (fr) Ribeiro et al 1129 (INPA MO NY); 3.VII.1963 (fr) Rodriguez et al. 13998 (INPA).

\section{Psychotria L.}

Arvoretas, árvores, arbustos ou ervas hermafroditas. Ramos cilíndricos ou quadrangulares; madeira tipicamente quebradiça. Estípulas interpeciolares, unidas ao redor do caule numa bainha geralmente bilobada ou num capuz cônico, persistentes ou decíduas. Folhas opostas, decussadas, subsésseis ou geralmente pecioladas. Inflorescências terminais, paniculadas ou corimbiformes, tirsóides, cimosas ou capitadas, verdes ou coloridas, com brácteas às vezes bem desenvolvidas. Flores bissexuais, geralmente distílicas; cálice subtruncado ou 5lobado; corola tubular ou infundibuliforme, geralmente alva, amarela ou esverdeada, glabra ou pubescente no interior, tubo com base estreita, 5-lobada, prefloração valvar; estames 5 , inseridos na porção mediana a superior do tubo da corola, anteras dorsifixas, inclusas ou exsertas; ovário 2-locular, óvulos 1 por lóculo; estigma 2-partido. Frutos drupáceos, elipsóides ou subglobosos, às vezes bilobados, carnosos, vermelhos, alaranjados, arroxeados, azuis ou negros; pirênios 2, 1-loculares, planoconvexos, geralmente costados.

Gênero pantropical que compreende mais de 1000 espécies, com possivelmente 600 espécies neotropicais (Taylor et al., 2004). Psychotria é relacionada com Palicourea, sendo que Palicourea se distingue pela corola gibosa na base, geralmente amarela, vermelha, arroxeada ou azul, e com o interior da corola possuindo um anel de tricomas abaixo do terço inferior do tubo. Psychotria é também frequentemente confundida com Rudgea; em Rudgea as estípulas são glandular-setosas a 
laciniadas e nunca bilobadas. Na América do Sul Psychotria compreende dois subgêneros, o subg. Psychotria, com estípulas interpeciolares ou caliptradas e decíduas e frutos vermelhos ou alaranjados, e o subg. Heteropsychotria, com estípulas persistentes, geralmente unidas ao redor do caule formando um tubo e bilobadas, e os frutos geralmente azuis ou negros. Ronabea e Margaritopsis foram recentemente separados de Psychotria (ver chave para os gêneros) enquanto Carapichea Aubl. provavelmente merece ser segregado, porém sua delimitação ainda não é muito bem compreendida. A distribuição espacial, o habitat e a riqueza de espécies de Psychotria e gêneros relacionados na Reserva Ducke foram estudadas por Kinupp (2002) e Kinupp \& Magnusson (2005).

\section{Chave para as espécies de Psychotria}

1. Ervas prostradas 28. P. variegata

1. Ervas eretas, subarbustos, arbustos, arvoretas ou árvores.

2. Inflorescências capitadas ou glomeruladas, não ramificadas, flores inseridas num mesmo ponto, sésseis a subsésseis.

3. Inflorescências com brácteas involucrais estreitas (0,5-2 mm larg.), flores não ocultas pelas brácteas.

4. Estípulas laceradas, com vários lobos lineares; inflorescências com pedúnculos 2,5-4,5 cm compr 23. P. sphaerocephala

4. Estípulas bilobadas, lobos triangulares; inflorescências sésseis ou subsésseis.

5. Folhas glabras na face adaxial; inflorescências subsésseis

3. P. bremekampiana

5. Folhas hirsutas ou hirtelas na face adaxial; inflorescências sésseis 11. P. iodotricha

3. Inflorescências protegidas por brácteas involucrais largas (5-30 mm larg.), flores parcialmente ocultas pelas brácteas.

6. Brácteas involucrais truncadas ou arredondadas; estípulas truncadas ou com lobos deltóides, 0,5-1,5 mm compr. ou estreitamente triangulares e 3-6 mm compr.

7. Estípulas com lobos 3-6 mm compr.; pedúnculo 10-15 mm compr.

27. P. turbinella

7. Estípulas truncadas ou com lobos $0,5-1,5 \mathrm{~mm}$ compr.; pedúnculo ausente ou até $5 \mathrm{~mm}$ compr.

8. Inflorescências eretas, esbranquiçadas, com brácteas involucrais 15$18 \mathrm{~mm}$ compr. 1. P. apoda

8. Inflorescências pêndulas, verdes, com brácteas 5-8 mm compr.

18. P. platypoda

6. Brácteas involucrais agudas ou acuminadas; estípulas bilobadas com lobos estreitamente triangulares a lineares, $2-16 \mathrm{~mm}$ compr.

9. Plantas glabras ou pubérulas

4. P. colorata

9. Plantas pilosas ou hirsutas.

10. Inflorescências com brácteas involucrais 2, ovadas, 20-30 mm larg... 19. P. poeppigiana

10. Inflorescências com brácteas involucrais 4-6, lanceoladas, 4-6 mm larg 21. P. prancei

2. Inflorescências ramificadas ao menos uma vez, cimosas a paniculadas.

11. Brácteas florais ausentes ou até $1 \mathrm{~mm}$ compr., não ultrapassando nem recobrindo o cálice. 12. Estípulas inteiras, oblanceoladas ou obovadas, decíduas ...15. P. mapourioides 
12. Estípulas bilobadas, geralmente persistentes.

13. Estípulas (bainha + lobos) $11-20 \mathrm{~mm}$ compr.

16. P. microbotrys

13. Estípulas (bainha + lobos) $0,5-8 \mathrm{~mm}$ compr.

14. Nervuras secundárias atingindo a margem da folha, margem geralmente espessada.

15. Flores separadas em címulas dicotômicas

25. P. subundulata

15. Flores agrupadas em glomérulos.

16. Flores em glomérulos 2-3-floros, cada ramo secundário da inflorescência com $2-5$ glomérulos

12. P. longicuspis

16. Flores em glomérulos 5-7-floros, cada ramo secundário da inflorescência com apenas 1 glomérulo

20. P. polycephala

14. Nervuras secundárias reticuladas, não atingindo a margem da folha, margens não espessadas.

17. Flores sésseis em glomérulos produzidos nos ramos finais das inflorescências; frutos bilobados, pirênios lisos

5. P. cornigera

17. Flores subsésseis ou curtamente pediceladas, distribuídas nos ramos secundários da inflorescência; frutos elipsóides ou subglobosos, pirênios verrucosos ou costados.

18. Estípulas com lobos ca. $0,5 \mathrm{~mm}$ compr.

14. P. manausensis

18. Estípulas com lobos $1-5 \mathrm{~mm}$ compr.

19. Pirênios verrucosos; frutos $3-3,5 \times 2,5-3 \mathrm{~mm}$; nervuras laterais 5-10 pares

6. P. deflexa

19. Pirênios com cristais longitudinais e faces planas; frutos $3,5-4 \times$ 4,5-5,5 mm; nervuras laterais $11-13$ pares ....17. P. paniculata

11. Brácteas florais 2,5-20 mm compr., ultrapassando e cobrindo o cálice.

20. Brácteas da inflorescência elípticas, oblanceoladas, ovadas ou lanceoladas, $3-15 \mathrm{~mm}$ larg.; corola tubular ou estreitamente infundibuliforme, com tubo 9-20 mm compr.

21. Estípulas (bainha + lobos) $10-20 \mathrm{~mm}$ compr.

24. P. stipulosa

21. Estípulas (bainha + lobos) $0,5-9 \mathrm{~mm}$ compr.

22. Brácteas da inflorescência lanceoladas a ovadas; folhas com nervuras secundárias geralmente salientes na face adaxial.... 10. P. humboldtiana

22. Brácteas da inflorescência elípticas a oblanceoladas; folhas com nervuras secundárias planas na face adaxial.

23. Lobos das estípulas 3-7 mm compr.; tubo da corola c. $5 \mathrm{~mm}$ compr. ....... 13. P. lupulina

23. Lobos das estípulas $0,5-1 \mathrm{~mm}$ compr.; tubo da corola $9-10 \mathrm{~mm}$ compr .. 22. P. rhombibractea

20. Brácteas da inflorescência elípticas a lineares, 1-5 mm larg.; corola infundibuliforme, com tubo 3-14 mm compr.

24. Ramos da inflorescência hirsutos ou hirtelos

26. P. trichocephala

24. Ramos da inflorescência glabros ou pubérulos.

25. Nervuras laterais da folha atingindo a margem espessada

7. P. egensis

25. Nervuras laterais reticuladas, não atingindo a margem da folha.

26. Folhas com nervuras intersecundárias bem desenvolvidas, mais longas que as nervuras secundárias 2. $P$. araguariensis

26. Folhas sem nervuras intersecundárias ou as mesmas inconspícuas, não atingindo a metade das nervuras secundárias. 
27. Brácteas principais da inflorescência $18-23 \mathrm{~mm}$ compr. 13. P. lupulina

27. Brácteas principais da inflorescência $3-8 \mathrm{~mm}$ compr.

28. Brácteas florais elípticas, 2-4 mm long.

8. P. gracilenta

28. Brácteas florais estreitamente triangulares, $4-8 \mathrm{~mm}$ compr. ....9. P. hoffmannseggiana

27.1 Psychotria apoda Steyerm., Mem. New York Bot. Gard. 23: 668. 1972.

Ervas ou subarbustos, ca. $20 \mathrm{~cm}$ alt. Ramos cilíndricos ou quadrangulares, glabros. Estípulas unidas ao redor do ramo, glabras ou pubérulas, persistentes, $2-4,5 \mathrm{~mm}$ compr., truncadas ou arredondadas. Folhas pecioladas; pecíolo $0,7-1,5 \mathrm{~cm}$ compr.; lâmina elíptica ou elíptico-oblonga, $8-14 \times 2-5 \mathrm{~cm}$, ápice acuminado, base cuneada ou obtusa, papirácea, glabra ou pubérula; nervuras laterais 12-15 pares, planas na face adaxial. Inflorescências terminais, capitadas, glabras ou pubérulas, esbranquiçadas, sésseis, 1,5-2,5 $\mathrm{cm}$ diâm., com brácteas involucrais, as externas oblongas ou liguladas, $1,5-1,8 \mathrm{~cm}$ compr., truncadas. Flores com cálice 1-1,5 mm compr., brevemente lobado; corola tubular ou infundibuliforme, alva, externamente glabra, tubo 1-1,2 cm compr., lobos ca. $2 \mathrm{~mm}$ compr. Drupas elipsóides, ca. 1,2 × 1,5 cm, azuis; pirênios 2, com 3-5 costas longitudinais.

Ocorre na Colômbia, Venezuela, as Guianas e ao norte e noroeste do Brasil. Na Reserva, foi coletada apenas em floresta de baixio e com flores em outubro (Campos \& Brito 1999: pág. 639). 25.X.1994 (fl) Sothers 239 (INPA).

27.2 Psychotria araguariensis Steyerm., Mem. New York Bot. Gard. 23: 588. 1972.

Arvoretas ou arbustos até $5 \mathrm{~m}$ alt., ca. $3,5 \mathrm{~cm}$ diâm. Tronco circular de base reta. Ritidoma marrom escuro, com anéis transversais e lenticelas; exterior da casca marrom; casca internamente marrom com estria bege; alburno amarelo; odor suave. Ramos cilíndricos, glabros. Estípulas unidas ao redor do ramo, glabras, persistentes, 3-4 mm compr., lobos 2 de cada lado, obtusas ou agudas, às vezes curto-aristadas. Folhas pecioladas; pecíolos $0,5-1,2 \mathrm{~cm}$ compr.; lâmina elíptica, 9-20 × 2,5-7 cm, ápice acuminado, base cuneada ou aguda, papirácea, glabra; nervuras laterais 18-20 pares, planas na face adaxial, unidas numa nervura submarginal próxima à margem. Inflorescências terminais, glabras, tirsóides, piramidais; pedúnculo 3,5-7 cm compr.; porção ramificada $1-4 \times 3-6 \mathrm{~cm}$, subcapitada a congesta, com ramos secundários curtos ou desenvolvidos; brácteas 2-12 mm compr. Flores sésseis em glomérulos 5-7floros; cálice 1-1,2 mm compr., truncado ou denticulado; corola infundibuliforme, alva, externamente glabra, tubo 13-14 mm compr., lobos ca. 2,5 mm compr., abaxialmente corniculados. Drupas elipsóides, 7-8 mm diâm., amarelas ou alaranjadas a vináceas; pirênios 2 , com 3-5 costas longitudinais pouco distintas.

Endêmica do Brasil, nos estados do norte da Amazônia. Identificada erroneamente como Psychotria pacimonica Müll. Arg. (Campos \& Brito 1999: pág. 627, 639; Kinupp 2002, fig. 12a, b, c), esta espécie é descrita como comum dentro da Reserva Ducke (Kinupp 2002), onde foi coletada em floresta de campinarana e baixio, com flores em fevereiro e março, com frutos maio a agosto.

12.III.1996 (fl) Campos \& Silva 543 (INPA), 12.II.1996 (fl) Campos et al. 481 (INPA MO), 16.VI.1994 (fr) Ribeiro \& Assunção 1325 (INPA MO SPF); 14.VII.1977 (fr) Silva et al. 2133 (INPA MO); 31.V.1995 (fr) Vicentini et al. 984 (INPA MO SPF); 3.II.1995 (fl) Vicentini et al. 840 (INPA MO SPF); 7.VIII.1995 (fr) Nee et al. 46191 (INPA SPF).

27.3 Psychotria bremekampiana Steyerm., Mem. New York. Bot. Gard. 23: 643. 1972.

Ervas ou subarbustos, ca. $0,5 \mathrm{~m}$ alt. Ramos prostrados ou eretos, cilíndricos, densamente hirtelos a pilosos. Estípulas unidas ao redor do caule, hirtelas a pilosas, persistentes, bainha 1,5-2 mm compr., lobos 2 de cada lado, triangulares ou lanceoladas, 4-5 mm compr. Folhas pecioladas; pecíolo 3-5 $\mathrm{mm}$ compr.; 
lâmina elíptica ou oblanceolada, 5-11 ×2-4,5 $\mathrm{cm}$, ápice agudo, base cuneada ou obtusa, papirácea, glabra na face adaxial, hirtela a pilosa na face abaxial; nervuras laterais 10-12 pares, planas ou ligeiramente impressas na face adaxial, ligeiramente salientes na face abaxial. Inflorescências terminais, capitadas, hirsutas ou hirtelas, pedúnculo 5-21 mm compr., glomérulos 5-10 mm diâm., sem brácteas involucrais, com brácteas estreitamente triangulares, 3-8 mm compr. Flores sésseis; cálice 4-4,5 mm compr., lobos estreitamente triangulares; corola infundibuliforme, alva a amarela, externamente pilosa, tubo 6-8 mm compr., lobos 2-2,5 mm compr. Drupas subglobosas, ca. $4 \mathrm{~mm}$ diâm., arroxeadas a azuis; pirênios 2, com 3-5 costas longitudinais.

Ocorre nas Guianas e no Brasil, nos estados do norte da Amazônia. Previamente, foi errôneamente determinada como Psychotria sciaphila S. Moore (Campos \& Brito 1999: pág. 635; Kinupp 2002, fig. 4b). Trata-se de uma espécie comum na Reserva Ducke, especialmente na floresta de platô e de vertente, sendo também encontrada nos baixios; e foi observada frequentemente formando populações monoespecíficas densas (Kinupp 2002). Foi coletada com flores em dezembro e com frutos em março.

2.XII.1994 (fl) Costa \& Nascimento 39 (INPA); 5.III.1996 (fr) Campos \& Silva 534 (INPAMO SPF).

27.4 Psychotria colorata (Willd. ex Roem. \& Schult.) Müll. Arg., Fl. bras. 6(5): 372. 1881.

Arbustos ou subarbustos, até $1 \mathrm{~m}$ alt. Ramos cilíndricos ou quadrangulares, puberulentos ou glabros. Estípulas unidas ao redor do caule, glabras ou pubérulas, persistentes, bainha 1,5-3 $\mathrm{mm}$ compr., truncada ou em forma de $\mathrm{U}$, lobos 2 de cada lado, estreitamente triangulares, 2-9 $\mathrm{mm}$ compr. Folhas pecioladas; pecíolo 2-15 mm compr.; lâmina elíptica ou elíptico-oblonga, 7$20 \times 2,5-8 \mathrm{~cm}$, ápice acuminado, base cuneada ou obtusa, papirácea, glabra ou pubérula; nervuras laterais 8-19 pares, planas na face adaxial, salientes na face abaxial. Inflorescências terminais, capitadas, glabras ou pubérulas, rosadas ou purpúreas, pedúnculo 0,5-6 cm compr., glomérulos 1,5-2 $\times 3-5 \mathrm{~cm}$, com brácteas involucrais externas 2 , ovadas, 2-3,5 cm compr., agudas ou acuminadas, curtamente unidas na base. Flores sésseis; cálice 1-2 mm compr., lobado; corola infundibuliforme, alva a rosada ou purpúrea, glabra externamente, tubo 10-14 mm compr., lobos 2-3 mm compr. Drupas elipsóides, 5$5,5 \times 3-3,5 \mathrm{~mm}$, azuis ou purpúreas; pirênios 2 , com 3-5 costas longitudinais.

Ocorre nas Guianas, na Venezuela e na amazônia brasileira. Foi listada no guia de campo (Campos \& Brito 1999: pág. 639), porém não foi ilustrada. Apesar das estípulas terem sido descritas como truncadas ou em forma de $\mathrm{U}$, o espécime estudado possui estípulas bilobadas. $\mathrm{Na}$ Reserva Ducke, foi coletada apenas uma vez, na floresta de baixio, florescendo em setembro. 7.IX.1996 (fl) Assunção 379 (INPA MO).

27.5 Psychotria cornigera Benth., J. Bot. (Hooker) 3: 227. 1841.

Psychotria bahiensis var. cornigera (Benth.) Steyerm., Mem. New York Bot. Gard. 23: 518. 1972, syn. nov.

Ervas, subarbustos ou arbustos, até 1 $m$ alt. Ramos subcilíndricos, glabros. Estípulas unidas ao redor do caule, glabras, persistentes, bainha $0,5-1,5 \mathrm{~mm}$ compr., truncada ou em forma de $U$, lobos 2 de cada lado, deltóides ou triangulares, 1-2 $\mathrm{mm}$ compr. Folhas pecioladas; pecíolo 0,8-1,2 cm compr.; lâmina elíptica, $9-18 \times 3-8 \mathrm{~cm}$, ápice acuminado, base cuneada ou obtusa, papirácea, glabra; nervuras laterais 7-10 pares, planas na face adaxial, proeminentes na face abaxial. Inflorescências terminais, corimbiformes, cimosas, glabras, pedúnculo 5-20 mm compr., panícula 6-15 × 15-25 mm, geralmente ebracteada. Flores subsésseis em glomérulos 5-15-floros; cálice ca. 0,3 mm compr., subtruncado ou denteado; corola infundibuliforme, alva ou amarela, glabra externamente, tubo 7-10 mm compr., lobos 22,5 mm compr. Drupas bilobadas, 4-5 × 7-9 $\mathrm{mm}$, alaranjados a enegrecidos; pirênios 2 , lisos, hemisféricos. 
Ocorre na Colômbia, Peru, Guianas, Venezuela, Equador, Bolívia e na amazônia brasileira. Foi previamente tratada como Psychotria bahiensis var. cornigera (Campos \& Brito 1999: pág. 627, 639; Kinupp 2002, fig. 5 b), seguindo o conceito estabelecido por Steyermark (1972). Estudos subsequentes mostraram que Psychotria bahiensis DC. e P. cornigera são entidades distintas (Taylor et al. 2004). Kinupp (2002) considerou esta espécie como típica dos baixios, formando grandes populações monoespecíficas, aparentemente através de reprodução vegetativa. Na Reserva, foi coletada em floresta de baixio e floresta de platô, com flores em agosto e setembro, com frutos em março e agosto.

15.VIII.1995 (fl) Costa et al. 348 (INPA MO SPF); 4.IX.1990 (fl) Campos et al. 609 (INPA MO SPF); 6.III.1988 (fr) Santos \& Lima 849 (INPA MO); 22.III.1996 (fr) Campos et al. 581 (INPA MO SPF); 3.IX.1996 (fl) Campos \& Assunção 606 (INPA MO 606); 7.VIII.1995 (fr) Nee et al. 46194 (INPA SPF).

27.6 Psychotria deflexa DC., Prodr. 4: 510. 1830.

Arvoretas até $4 \mathrm{~m}$ alt. Ramos ligeiramente quadrangulares ou cilíndricos, glabros. Estípulas unidas ao redor do caule, glabras, persistentes, bainha $0,5-1 \mathrm{~mm}$ compr., truncada ou em forma de $U$, lobos 2 de cada lado, triangulares, 2-5 mm compr. Folhas pecioladas; pecíolo $0,2-1,5 \mathrm{~cm}$ compr.; lâmina elíptica, 7-20×3-8 cm, ápice acuminado, base aguda, papirácea, glabra; nervuras laterais 510 pares, planas na face adaxial, ligeiramente proeminentes na face abaxial. Inflorescências terminais, piramidais ou cilíndricas, cimosas, glabras ou pubérulas, geralmente ebracteadas, pedúnculo 3-7 cm compr. Flores sésseis em címulas dicotômicas 5-9-floras; cálice 0,1-0,5 $\mathrm{mm}$ compr., denteado; corola infundibuliforme, alva, glabra externamente, tubo $2-4 \mathrm{~mm}$ compr., lobos 1-1,5 mm compr. Drupas elipsóides ou bilobadas, 3-3,5 × 2,5-3 mm, azuis a enegrecidos; pirênios 2 , hemisféricos, verrugosos.

Ocorre no México, Caribe, Paraguai e Brasil, onde é amplamente distribuída. Na
Reserva, foi coletada em floresta de campinarana com flores em dezembro (Campos \& Brito 1999: pág. 637).

12.XII.1998 (fl) Souza et al. 518A (INPA MO).

27.7 Psychotria egensis Müll. Arg., Flora 59: 542, 545. 1876.

Arbusto ou arvoretas, $1 \mathrm{~m}$ alt. Ramos quadrangulares, glabros. Estípulas unidas ao redor do caule, glabras, persistentes, bainha $0,5-$ $2 \mathrm{~mm}$ compr., truncada, lobos 2 de cada lado, triangulares, 1-2 mm compr. Folhas pecioladas; pecíolo 3-10 mm compr.; lâmina elíptica ou obovada, 9-16 × 2-7 cm, ápice acuminado, base cuneada ou obtusa, cartácea, glabra, com margens finamente cartilaginosas; nervuras laterais 6-9 pares, planas na ambas as faces, unidas às margens cartilaginosas. Inflorescências terminais, piramidais, glabras, subcapitadas a paniculadas, pedúnculo $2-3 \mathrm{~cm}$ compr., ramos secundários terminando em um 3(-5) capítulos, brácteas 2-13 mm compr. Flores sésseis em grupos de 5-7 flores; cálice ca. 0,2 $\mathrm{mm}$ compr., denteado; corola infundibuliforme, alva, externamente glabra, tubo ca. $3.5 \mathrm{~mm}$ compr., lobos ca. $1.5 \mathrm{~mm}$ compr. Drupas elipsóides, 4-5 mm diâm., negros; pirênios 2, com 3-5 costas longitudinais.

Ocorre na Venezuela, Colômbia e Brasil, na região amazônica. Na Reserva Ducke, foi registrada pela primeira vez por Kinupp (2002, fig. 7), tendo sido_coletada com flores em março e junho (Kinupp 2002). 2001, Кinирp 1838 (INPA), 1844 (INPA).

27.8 Psychotria gracilenta Müll. Arg., Flora 59: 545. 1876.

Psychotria brachybotrya Müll. Arg., Fl. bras. 6(5): 327. 1881.

Arbustos, até $2 \mathrm{~m}$ alt. Ramos quadrangulares ou cilíndricos, glabros. Estípulas unidas ao redor do caule, glabras, persistentes, bainha $0,5-1 \mathrm{~mm}$ compr., truncada ou em forma de $U$, lobos 2 em cada lado, deltóides ou triangulares, 1-3 mm compr. Folhas pecioladas; pecíolo 0,3-1 cm compr.; lâmina elíptica, 9-19×3-8 cm, ápice acuminado, base obtusa, papirácea, glabra; nervuras laterais 
7-10 pares, planas na face adaxial, salientes na face abaxial. Inflorescências terminais, glabras ou pubérulas, paniculadas a subcapitadas, pedúnculo 5-12 $\mathrm{mm}$ compr., panícula piramidal ou corimbiforme, $1-2 \times 1-$ $2,5 \mathrm{~cm}$; ramos secundários 2-6; brácteas elípticas, 2-9 mm compr. Flores sésseis em grupos de 4-7 flores; com cálice ca. 0,5 mm compr., denteado; corola infundibuliforme ou hipocrateriforme, alva, externamente glabra ou pubescente, tubo 1,5-3 mm compr., lobos ca. $1 \mathrm{~mm}$ compr. Drupas elipsóides, $4-5 \mathrm{~mm}$ diâm., negras a purpúreas (ocasionalmente alvas); pirênios 2, com 3-5 costas longitudinais.

Ocorre na América Central, Colômbia, Equador, Peru, Guianas, Venezuela, Bolívia e Brasil, onde é amplamente distribuída. Inicialmente esta espécie foi tratada sob o nome de Psychotria brachybotrya (Campos \& Brito 1999: pág. 627, 637; Kinupp 2002, fig. 5c, d) porém $P$. gracilenta tem prioridade sobre esse nome (Taylor et al. 2004). Kinupp (2002) notou que apesar da maioria dos frutos dessa espécie serem negros a purpúreos, estes podem ocasionalmente ser alvos; não fica claro na discussão de Kinupp se a cor dos frutos de uma mesma planta é consistente ou se esta varia em um mesmo espécime. Dimorfia na cor dos frutos (azul a alvo, atropurpúreo ou alvo) é encontrada em outras espécies de Psychotria e em outros gêneros de Rubiaceae, e possivelmente acarreta benefícios para a planta ao atrair potencialmente mais de um agente dispersor. $\mathrm{Na}$ Reserva, foi coletada em floresta de baixio, floresta de platô e floresta de vertente, com flores em março e abril e com frutos em junho. 29.VI.1993 (fr) Ribeiro et al. 914 (INPA MO SPF); 18.III.1996 (fl) Campos et al. 552 (INPA MO SPF); 9.IV.1995 (fl) Costa et al. 189 (INPA).

27.9 Psychotria hoffmannseggiana (Willd. ex Roem. \& Schult.) Müll. Arg., Fl. bras. 6(5): 336. 1881.

Psychotria barbiflora DC., Prodr. 4: 509. 1830.

Ervas, arbustos ou arvoretas até 4,5 m alt. Tronco circular, liso. Ramos quadrangulares ou cilíndricos, glabros. Estípulas unidas ao redor do caule, glabras, persistentes, bainha $0,5-1$ mm compr., truncada ou em forma de $U$, lobos 2 de cada lado, deltóides ou triangulares, 0,5$3 \mathrm{~mm}$ compr. Folhas opostas, pecioladas; pecíolo 3-8 mm compr.; lâmina elíptica, 7-15 $\times 2,8-7 \mathrm{~cm}$, ápice acuminado, base obtusa ou arredondada, papirácea, glabra; nervuras laterais $7-10$ pares, planas em ambas as faces ou proeminentes na face abaxial. Inflorescências terminais, glabras, corimbiformes a subcapitadas, pedúnculo 3-8 mm compr., panícula 5-10 $\times 1-2,5 \mathrm{~cm}$, ramos secundários 2-6, geralmente radiais, brácteas estreitamente triangulares, $3-8 \mathrm{~mm}$ compr. Flores sésseis em grupos de 5-15 flores; cálice ca. 0,8 mm compr., denteado; corola infundibuliforme, alva, externamente glabra ou pubescente, tubo 3-3,5 mm compr., lobos 11,5 mm compr. Drupas elipsóides, 4-5 mm diâm., negras; pirênios 2, hemisféricos, com 3-5 costas longitudinais.

Ocorre na Colômbia, Equador, Peru, Guianas, Venezuela e em todo o Brasil. Steyermark (1972) reconheceu Psychotria hoffmannseggiana e P. barbiflora como espécies distintas, mas estudos mais recentes demonstram que estes nomes foram aplicados para formas diferentes de uma espécie extremamente variável (Taylor et al. 2004). $\mathrm{Na}$ Reserva, foi coletada na floresta de vertente e campinarana e nas capoeiras, com flores em fevereiro, agosto e outubro, com frutos de janeiro a fevereiro (Campos \& Brito 1999: pág. 627, 636; sob Psychotria barbiflora).

11.X.1995 (fl) Sothers \& Pereira 617 (INPA); 13.II.1996 (fr) Campos et al. 482 (INPA MO SPF); 27.II.1996 (fl) Campos et al. 525 (INPA); 9.VIII.1994 (fl) Vicentini et al. 668 (INPA MO SPF); 26.VIII.1997, Souza et al. 404 (INPA MO); 1.I.1998 (fr) Brito \& Assunção 55 (INPA MO).

27.10 Psychotria humboldtiana (Cham.) Müll. Arg., Fl. bras. 6(5): 333. 1881.

Arbustos ou arvoretas até $3 \mathrm{~m}$ alt., ca. $1.5 \mathrm{~cm}$ diâm. Tronco com raízes de suporte na base. Ritidoma liso, verde-acastanhado, com lenticelas. Ramos quadrangulares ou cilíndricos, glabros. Estípulas unidas ao redor 
do caule, glabras, persistentes, bainha $0,5-1,5$ mm compr., truncada ou em forma de $U$, lobos 2 de cada lado, triangulares ou lineares, 1-2,5 mm compr. Folhas opostas, pecioladas, glabras; pecíolos 0,2-1 cm compr.; lâmina elíptica ou elíptico-oblonga, 9-17 ×0,8-3 cm, ápice acuminado, base aguda ou cuneada, papirácea; nervuras laterais $12-18$ pares, proeminentes em ambas as faces. Inflorescências terminais, glabras, corimbiformes a subcapitadas, pedúnculo $1-3,5 \mathrm{~cm}$ compr., panícula $2-5,5 \times$ 2,5-6,5 cm, brácteas elípticas ou ovadas, 10 $18 \mathrm{~mm}$ compr., rosadas a arroxeadas, obtusas ou arredondadas. Flores sésseis em glomérulos 5-8-floros; cálice 2,5-4 mm compr., denteado; corola tubular, alva ou rosada, externamente glabra, tubo 18-20 mm compr., lobos 3-4 mm compr. Drupas elipsóides, ca. $7 \times 3 \mathrm{~mm}$, brancas; pirênios 2, hemisféricos, lisos ou com 3-5 costas longitudinais.

Ocorre na Colômbia, Guianas, Venezuela e na amazônia brasileira. Na Reserva ocorre em baixios e campinarana hidromórfica (Kinupp 2002: fig. 8) e foi coletada com flores em maio, junho e outubro e com frutos em março (Campos \& Brito 1999: pág. 627, 636). 15.V.1995 (fl) Cordeiro et al. 1564 (INPA); 13.VI.1996 (fl) Assunção 296 (INPA); 23.III.1994 (fr) Ribeiro et al. 1245 (INPA MO SPF); 27.X.1994 (fl) Sothers et al. 248 (INPA MO SPF).

27.11 Psychotria iodotricha Müll. Arg., Fl. bras. 6(5): 375. 1881.

Ervas ou subarbustos até $0,5 \mathrm{~m}$ alt., prostradas. Ramos cilíndricos, densamente hirtelos a pilosos. Estípulas unidas ao redor do caule, hirtelas ou pilosas, persistentes, bainha 3-5 mm compr., lobos 2 do cada lado, estreitamente triangulares, 3-5 $\mathrm{mm}$ compr. Folhas opostas, pecioladas; pecíolo $2-4 \mathrm{~mm}$ compr.; lâmina elíptica, 5,5-12 × 2,5-6 cm, ápice agudo, base obtusa, arredondada ou truncada, papirácea, hirsuta ou hirtela; nervuras laterais 9-13 pares, planas na face adaxial, ligeiramente salientes na face abaxial. Inflorescências terminais, sésseis, capitadas, hirsutas, 10-15 mm diâm., sem brácteas involucrais, com brácteas lineares florais. Flores sésseis; cálice 5-6 mm compr., lobado; corola salverforme, alva a amarela, externamente pilosa, tubo ca. $8 \mathrm{~mm}$ compr., lobos ca. $2 \mathrm{~mm}$ compr. Drupas elipsóides, ca. 4 mm diâm., lilases, arroxeadas a azuladas; pirênios 2 , hemisféricos, com 3-5 costas longitudinais.

Ocorre na Venezuela, Peru e no Brasil, nos estados do norte da Amazônia. O nome da espécie aparece com a grafia incorreta como “idiotricha" em Campos \& Brito (1999: pág. $627,635)$. Os mesmos autores observaram que os tricomas dessa espécie apresentam frequentemente coloração arroxeada, e Kinupp (2002: fig. 4c, d, fig. 9) subsequentemente descreveu dois morfotipos, o "morfotipo peludo" e o "morfotipo folha fina". Na Reserva, foi coletada na floresta de vertente e platô, com flores em setembro e dezembro e com frutos em dezembro e março.

2.IX.1996 (fl) Campos \& Silva 603 (INPAMO SPF); 22.III.1996 (fr) Campos et al. 582 (INPA MO); 5.XII.2001 (fl,fr), Groppo et al. 927 (INPA SPF).

27.12 Psychotria longicuspis Müll. Arg., Flora 59: 549, 552. 1876

Psychotria cincta Standl., Publ. Field Columbian Mus., Bot. Ser. 7: 90. 1930.

Arbustos até $2 \mathrm{~m}$ alt. Ramos quadrangulares ou cilíndricos, glabros. Estípulas unidas ao redor do caule, glabras, persistentes, bainha 1-2 mm compr., truncada ou em forma de $U$, lobos 2 do cada lado, lineares, 1-3 mm compr. Folhas opostas, pecioladas; pecíolo 5-15 mm compr.; lâmina elíptica ou elíptico-oblonga, 8,5-20×2,5$9 \mathrm{~cm}$, ápice acuminado, base obtusa ou arredondada, papirácea, glabra, com margem espessada; nervuras laterais 7-12 pares, planas em ambas as faces, unidas na margem espessada. Inflorescências terminais, glabras, paniculadas, cilíndricas a estreitamente piramidais, pedúnculo 2,5-6 cm compr., panícula 5,5-10 × 2-4 cm, brácteas 0,5-2 mm compr. Flores sésseis em glomérulos 2-3-floros; cálice ca. $0,2 \mathrm{~mm}$ compr., subtruncado; corola infundibuliforme, alva, externamente glabra, tubo ca. 2 mm compr., lobos ca. 1 mm compr. Drupas elipsóides, 4-5 mm diâm., brancas; pirênios 2, hemisféricos, com 3-5 costas longitudinais. 
Ocorre na Costa Rica, Panamá, Colômbia, Equador, Peru, Guianas, Venezuela e na amazônia brasileira. Inicialmente, esta espécie foi tratada sob o nome Psychotria cincta (Campos \& Brito 1999: pág. 627, 637; Kinupp 2002, fig. 6a, b), porém estudos recentes concluíram que $P$. longicuspis tem prioridade sobre esse nome (Taylor et al. 2004). Na Reserva Ducke foi coletada em todos os ambientes, com flores em dezembro, com frutos de janeiro a abril.

10.III.1994 (fr) Ribeiro et al. 1226 (INPA MO SPF); 8.IV.1995 (fr) Costa et al. 179 (INPA MO SPF); 9.XII.1994 (fl) Costa \& Nascimento 37 (INPA MO SPF); $18 . \mathrm{I} .1995$ (fr) Costa \& Nascimento 110 (INPA); 5.III.1996 (fr) Campos \& Silva 533 (INPAMO SPF).

27.13 Psychotria lupulina Benth., J. Bot. (Hooker) 2: 320. 1841.

Arbustos até 1,5 $\mathrm{m}$ alt. Tronco cilíndrico, verde. Ramos quadrangulares tornando-se cilíndricos, glabros. Estípulas unidas ao redor do caule, glabras, persistentes, bainha 1-1,5 $\mathrm{mm}$ compr., truncada ou em forma de $U$, lobos 2 de cada lado, lineares, 3-7 mm compr. Folhas opostas, pecioladas; pecíolo $1-3 \mathrm{~mm}$ compr.; lâmina elíptica, 6-16×2-6,5 cm, ápice agudo ou ligeiramente acuminado, base cuneada, papirácea, glabra; nervuras laterais 7-9 pares, planas na face adaxial, salientes na face abaxial. Inflorescências terminais, glabras, corimbiformes ou subcapitadas, pedúnculo $1-2,5 \mathrm{~cm}$ compr., panícula $1-2 \times$ 1-3 cm, brácteas lineares ou estreitamente oblanceoladas, 1-2,3 cm compr. Flores sésseis em glomérulos 5-15-floros; cálice ca. $1 \mathrm{~mm}$ compr., denteado ou subtruncado; corola hipocrateriforme, alva, externamente glabra, tubo ca. $5 \mathrm{~mm}$ compr., lobos ca. $3 \mathrm{~mm}$ compr. Drupas subglobosas, 3-4 mm diâm., negras; pirênios 2, hemisféricos, com 3-5 costas longitudinais arredondadas.

Ocorre na Colômbia, Guianas, Equador, Peru, Bolívia, Venezuela e na amazônia brasileira. Esta espécie foi previamente erroneamente identificada como Psychotria lindenii Standl. em herbários. Psychotria lupulina é uma espécie amplamente distribuída e morfologicamente variável, contando com diversos táxons infra-específicos (Steyermark 1972, Taylor 2005). Segundo os conceitos de Steyermark, algumas das plantas da Reserva Ducke encaixam-se sob P. lupulina subsp. rhodoleuca (Müll. Arg.) Steyerm., com brácteas da inflorescência estreitas (Assunção 378), enquanto outras apresentam o perfil de P. lupulina subsp. lupulina, com brácteas elípticas a obovadas (Davidson \& Martinelli 10012). Na Reserva, foi coletada apenas com flores, em setembro, infelizmente o tipo de habitat ocupado pela espécie não foi registrado. 7.IX.1996 (fl) Assunção 378 (INPA MO); 25.V.1980, Davidson \& Martinelli 10012 (MO).

27.14 Psychotria manausensis Steyerm., Mem. New York Bot. Gard. 23: 516. 1972.

Arvoretas ou arbustos até $4 \mathrm{~m}$ alt., ca. $5 \mathrm{~cm}$ diâm. Tronco cilíndrico, de base reta. Ritidoma verde com estrias longitudinais; exterior da casca verde, fibrosa; casca internamente creme; alburno creme, fibroso. Ramos cilíndricos, glabros. Estípulas unidas ao redor do caule, glabras, persistentes, bainha ca. $1 \mathrm{~mm}$ compr., truncada ou em forma de U, lobos 2 de cada lado, deltóides, ca. $0,5 \mathrm{~mm}$ compr. Folhas opostas, pecioladas; pecíolo 0,3-1,8 cm compr.; lâmina elíptica, 7-22×2$9 \mathrm{~cm}$, ápice acuminado, base cuneada ou aguda, papirácea, glabra ou pubérula; nervuras laterais 10-12 pares, planas na face adaxial, salientes na face abaxial. Inflorescências terminais, pubérulas, corimbiformes, paniculadas ou cimosas, pedúnculo $3-7 \mathrm{~cm}$ compr., panícula 1-5 × 4-9 cm, ramos secundários dicotômicos com flores isoladas e todas voltadas para o mesmo lado, brácteas geralmente uma para cada ramo secundário, lineares, 2-4 mm compr. Flores sésseis; cálice 0,1-0,2 mm compr., denteado, pubérulo; corola não vista. Drupas elipsóides, 4-5 mm diâm., arroxeadas ou vináceas; pirênios 2, hemisféricos, com 3-5 costas longitudinais.

É conhecida apenas dos arredores de Manaus. Conforme apontado por Kinupp (2002), esta espécie foi tanto erroneamente identificada como Psychotria adderleyi Steyerm. por 
Campos \& Brito (1999: pág. 627), como corretamente sob P. manausensis (pág. 637). Tratam-se de espécies muito semelhantes mas, através dos estudos de Kinupp (2002), ficou confirmado que os espécimes coletados na Reserva Ducke pertencem definitivamente a P. manausensis. Kinupp (2002: fig. 10A, B) observou que esta espécie apresenta variação na coloração dos frutos, que podem ser vináceos ou azuis, e que aparentemente a coloração é consistente para cada indivíduo, sendo que esta situação foi observada em outras espécies de Rubiaceae (ver discussão acima sob Psychotria cornigera). Na Reserva, foi coletada na floresta de vertente e platô, apenas com frutos em março, maio e junho.

6.VI.1993 (fr) Ribeiro et al. 882 (INPA MO SPF); 23.V.1995 (fr) Vicentini \& Silva 966 (INPA SPF); 20.VI.1993 (fr) Ribeiro et al. 944 (INPA MO SPF); 3.VI.1993 (fr) Ribeiro et al. 791 (INPA MO); 12.III.1996 (fr) Campos \& Silva 544 (INPAMO SPF).

27.15 Psychotria mapourioides DC., Prodr. 4: 509.1830.

Árvores ou arvoretas até $10 \mathrm{~m}$ alt., ca. $8 \mathrm{~cm}$ diâm. Tronco cilíndrico, com pequenas raízes tabulares na base, com anéis transversais bem marcados. Ritidoma marrom, estriado; exterior da casca fina; casca internamente com três camadas, castanhoclara, alaranjada e castanho-clara, ca. $2 \mathrm{~mm}$ de espessura; alburno esbranquiçado; odor suave. Ramos quadrangulares tornando-se cilíndricos, glabros. Estípulas interpeciolares, glabras, decíduas, elípticas, oblanceoladas ou obovadas, 8-23 mm compr., obtusas ou arredondadas. Folhas opostas, pecioladas; pecíolo 1-3 cm compr.; lâmina elíptica ou elíptico-oblonga, 8-20 × 3,5-10 cm, ápice agudo ou acuminado, base cuneada ou obtusa, cartácea, glabra; nervuras laterais 5-10 pares, planas ou salientes em ambas as faces. Inflorescências terminais, glabras, piramidais, paniculadas, pedúnculo $3-10 \mathrm{~cm}$ compr., panícula 5-10 × 5-11 cm, ebracteada ou as brácteas reduzidas, pedicelos $0,5-6 \mathrm{~mm}$ compr. Flores subsésseis ou pediceladas em címulas 5-15-floras; cálice 0,8-1 mm compr., denteado ou subtruncado; corola infundibuliforme, alva, externamente glabra, tubo ca. $3 \mathrm{~mm}$ compr., barbada na fauce, lobos ca. $2 \mathrm{~mm}$ compr. Drupas elipsóides, 5-7×4-6 mm, alaranjadas a arroxeadas; pirênios 2 , hemisféricos, com 3-5 costas longitudinais arredondadas.

Ocorre na Colômbia, Peru, Guianas, Trinidad, Venezuela e na amazônia brasileira. Na Reserva Ducke, foi estudada por Kinupp (2002: fig. 10c, d), tendo sido coletada apenas com flores, em abril (Campos \& Brito 1999: pág. 627, 647). 3.IV.1996 (fl) Vicentini \& Silva 1172 (INPAMO SPF).

27.16 Psychotria microbotrys Ruiz ex Standl., Publ. Field Columbian Mus., Bot. Ser. 8: 204. 1930.

Arbustos ou subarbustos até $3 \mathrm{~m}$ alt. Ramos ligeiramente quadrangulares ou cilíndricos, glabros. Estípulas interpeciolares ou brevemente unidas ao redor do caule, glabras, persistentes, ovadas, 11-20 mm compr., bilobadas até $1 / 2-2 / 3$, lobos agudos ou acuminados. Folhas pecioladas; pecíolo 1-3,5 cm compr.; lâmina elíptica, $14-27 \times 7-13 \mathrm{~cm}$, ápice agudo ou acuminado, base cuneada ou aguda, papirácea, glabra; nervuras laterais 1315 pares, planas na face adaxial, ligeiramente proeminentes na face abaxial. Inflorescências terminais, piramidais ou cilíndricas, cimosas, glabras ou pubérulas, pedúnculo $3,5-7 \mathrm{~cm}$ compr., panícula 6-8 $\times 4-4 \mathrm{~cm}$, geralmente ebracteada, pedicelos 0-2 mm compr. Flores sésseis ou pediceladas em címulas 3-9-floras; cálice ca. 0,3 mm compr., denteado; corola infundibuliforme, alva, glabra externamente, tubo 2-3.5 mm compr., lobos ca. $1 \mathrm{~mm}$ compr. , elipsóides ou subglobosas, 3-4 × 3-4 mm, azuis ou brancos; pirênios 2 , hemisféricos, verrugosos e/ou com 3-5 costas longitudinais.

Esta espécie ocorre na América Central, Bolívia e Brasil, na região amazônica. Foi registrada na Reserva Ducke pela primeira vez por Kinupp (2002, fig. 11c, d), que observou que esta é rara na área de estudo (Kinupp, 2002; Kinupp \& Magnusson, 2005). Na Reserva, foi coletada com flores em fevereiro (Kinupp 2001). 2001, Кinupp 1591 (INPA). 
27.17 Psychotria paniculata (Aubl.) Raeusch., Nomencl. Bot., ed. 3, 56. 1797.

Arvoretas até $5 \mathrm{~m}$ alt. Tronco cilíndrico, base reta. Ritidoma marrom-acinzentado com estrias longitudinais de desprendimento em escamas; exterior da casca marromacinzentada, ca. $1 \mathrm{~mm}$ espessura; casca internamente marrom com estrias alvas, fibrosa; alburno creme. Ramos quadrangulares ou subcilíndricos, glabros. Estípulas unidas ao redor do caule, glabras, persistentes, bainha 1-1,5 mm compr., truncada ou em forma de $U$, lobos 2 de cada lado, deltóides ou triangulares, 1-1,5 mm compr. Folhas opostas, pecioladas; pecíolo $0,5-1 \mathrm{~cm}$ compr., pubérulo ou glabro; lâmina elíptica, 15-23 $\times$ $5-7,5 \mathrm{~cm}$, ápice acuminado, base cuneada ou aguda, papirácea, glabra na face adaxial, pubérula na face abaxial; nervuras laterais 11-13 pares, planas na face adaxial, salientes na face abaxial. Inflorescências terminais, piramidais, pubérulas, paniculadas, pedúnculo 5-7 cm compr., panícula 5-7 $\times 5,5-$ $8 \mathrm{~cm}$, ebracteada ou as brácteas reduzidas. Flores subsésseis, agrupadas em címulas dicotômicas; cálice 0,2-0,3 mm compr., pubérulo; corola infundibuliforme, brancoamarelada, externamente pubérula, tubo ca. $4 \mathrm{~mm}$ compr., lobos ca. 1,5 mm compr. Drupas elipsóides, 3,5-4 × 4,5-5,5 mm, aplanadas; pirênios 2, hemisféricos, com 3-5 costas longitudinais arredondadas.

Esta espécie ocorre nas Guianas, no sul da Venezuela e Leste do Brasil. Foi registrada na Reserva Ducke (Campos \& Brito, 1999) e é também conhecida da região leste do estado do Amazonas (Maués). Trata-se de uma espécie muito semelhante a Psychotria subundulata, sendo que todos os espécimes coletados na Reserva Ducke e determinados como "Psychotria paniculata" estão incluídos sob $P$. subundulata. De qualquer modo, é possível que $P$. paniculata venha a ser encontrada na região de Manaus, portanto foi incluída no presente tratamento para auxiliar na identificação de espécies.
27.18 Psychotria platypoda DC., Prodr. 4: 510. 1830.

Arbustos ou subarbusto até $1,5 \mathrm{~m}$ alt. Ramos cilíndricos ou quadrangulares, glabros. Estípulas unidas ao redor do caule, glabras, persistentes, bainha 1-2 mm compr., lobos 2 de cada lado, deltóides, 0,5-1,5 mm compr. Folhas opostas, pecioladas; pecíolo $0,2-1,2$ cm compr.; lâmina elíptica, 8-19×3-7,5 cm, ápice acuminado, base cuneada ou obtusa, papirácea, glabra; nervuras laterais 6-16 pares, planas na face adaxial, ligeiramente salientes na face abaxial. Inflorescências terminais, glabras ou pubérulas, pêndulas, capitadas, verdes, pedúnculo 3-5 mm compr., glomérulo ca. $1 \times 1 \mathrm{~cm}$, brácteas externas oblongas ou liguladas, 5-8 mm compr., truncadas ou arredondadas. Flores sésseis; cálice ca. 0,8 mm compr., denteado; corola infundibuliforme, alva ou rosada, externamente glabra, tubo 7,5$8,5 \mathrm{~mm}$ compr., lobos $1-1,5 \mathrm{~mm}$ compr. Drupas elipsóides ou subglobosas, 2-4 mm compr., 3,5-4 mm larg., azuis ou violáceas; pirênios 2, hemisféricos, com 3-5 costas longitudinais.

Ocorre na Colômbia, Guianas, Venezuela e Brasil, na região amazônica. Na Reserva, ocorre geralmente em baixios e também na floresta de vertente e de platô (Kinupp 2002), tendo sido coletada apenas com flores, em janeiro e fevereiro (Campos \& Brito 1999: pág. 636). 23.I.1996 (fl) Sothers 782 (INPA); 15.II.1996 (fl) Campos et al. 493 (INPA MO); 5.I.1995, Costa \& Nascimento 71 (INPA MO SPF).

27.19 Psychotria poeppigiana Müll. Arg., Fl. bras. 6(5): 370.1881.

Arbustos até 1,5 m alt. Ramos cilíndricos ou quadrangulares, pilosos ou hirsutos. Estípulas unidas ao redor do caule, pilosos ou hirsutos, persistentes, bainha $2-5 \mathrm{~mm}$ compr., truncada ou em forma de $U$, lobos 2 de cada lado, estreitamente triangulares ou lineares, $4-16 \mathrm{~mm}$ compr. Folhas opostas, pecioladas; pecíolo 0,4 $3 \mathrm{~cm}$ compr.; lâmina elíptica, $8-24 \times 3-11 \mathrm{~cm}$, ápice agudo ou acuminado, base cuneada ou obtusa, papirácea, hirsuta ou pilosa; nervuras 
laterais 6-12 pares, planas na face adaxial, salientes na face abaxial. Inflorescências terminais, hirtelas ou hirsutas, capitadas, avermelhadas, pedúnculo $5-13 \mathrm{~cm}$ compr., glomérulo 1,5-2,5 × 3-8 cm (sem incluir as brácteas), brácteas involucrais externas 2 , ovadas, 3-6 cm compr., agudas ou acuminadas. Flores sésseis; cálice 0,5-2 mm compr., lobado; corola tubular, amarela, no exterior pilosa, tubo 10-15 mm compr., lobos $2-3 \mathrm{~mm}$ compr. Drupas elipsóides, 10-12 × 5-10 mm, azuis; pirênios 2 , hemisféricos, com 3-5 costas longitudinais.

Ocorre do México até a Bolívia e na amazônia brasileira. Campos \& Brito (1999: pág. 627,634) registraram o nome vernacular desta espécie como "Lábios-de-prostituta". $\mathrm{Na}$ Reserva, foi coletada em baixios e campinarana (Kinupp 2002: fig. 13), apenas com flores, em fevereiro, junho e agosto.

22.II.1996 (fl) Campos et al. 515 (INPA MO); 12.VIII.1994 (fl) Ribeiro \& Assunção 1391A (INPA MO SPF); 4.VI.1995 (fl) Sothers 485 (INPA MO); 18.I.1996 (fl) Pirani et al. 3656 (INPA SPF).

27.20 Psychotria polycephala Benth., J. Bot. (Hooker) 3: 231. 1841.

Ervas ou arbustos ca. 0,8 m alt. Ramos cilíndricos, glabros. Estípulas unidas ao redor do caule, glabras, persistentes, bainha $0,5-2 \mathrm{~mm}$ compr., truncada ou em forma de $U$, lobos 2 de cada lado, lineares, 1-3 mm compr. Folhas opostas, pecioladas; pecíolo 0,3-1 cm compr.; lâmina elíptica ou elíptico-oblonga, 4,5-13×1,5$4,5 \mathrm{~cm}$, ápice acuminado, base cuneada ou obtusa, papirácea, glabra, com margens levemente cartilaginosas; nervuras laterais 7-9 pares, planas em ambas as faces, unidas às margens espessas. Inflorescências terminais, cilíndricas a estreitamente piramidais, glabras, paniculadas, pedúnculo $1-4 \mathrm{~cm}$ compr., panícula 3-7 × 1-1,5 cm, cada ramo secundário terminando em uma glomérulo, brácteas $0,5-3$ mm compr. Flores sésseis em glomérulos 57-floros; cálice ca. 0,2 mm compr., denteado; corola infundibuliforme, alva, externamente glabra, tubo ca. $3 \mathrm{~mm}$ compr., lobos ca. $1 \mathrm{~mm}$ compr. Drupas elipsóides, 2-2,5 mm diâm., negras; pirênios 2, hemisféricos, com 3-5 costas longitudinais.

Ocorre nas Guianas, Venezuela e Brasil, na região amazônica. Kinupp (2002) observou que esta espécie forma populações monoespecíficas através de reprodução vegetativa, e sugeriu que os seus frutos poderiam ser dispersos pela água. Na Reserva, foi coletada em campinarana, baixios e os margens de igarapés, às vezes dentro d'água (Kinupp 2002), com flores em março e frutos em abril (Campos \& Brito 1999: pág. 636). 22.III.1994 (fl) Ribeiro et al. 1239 (INPA SPF); 1.IV.1996 (fr) Campos \& Silva 590 (INPA MO SPF); 12.XII.1998, Souza 517 (INPA MO).

27.21 Psychotria prancei Steyerm., Mem. New York Bot. Gard. 23: 656. 1972.

Arbustos ou arvoretas até $3 \mathrm{~m}$ alt. Ramos cilíndricos, pilosos ou hirsutos. Estípulas unidas ao redor do caule, pilosas ou hirsutas, persistentes, bainha 1,5-3 mm compr., lobos 2 de cada lado, estreitamente triangulares ou lineares, 2-7 mm compr. Folhas opostas, pecioladas; pecíolo 3-5 mm compr.; lâmina elíptica ou elíptico-oblonga, 7-15×2,5-6,5 cm, ápice agudo ou acuminado, base cuneada ou obtusa, papirácea, hirsuta ou pilosa; nervuras laterais 9-14 pares, planas na face adaxial, planas ou ligeiramente salientes na face abaxial. Inflorescências terminais, capitadas, pilosas ou hirtelas, verdes, vináceas ou avermelhadas, pedúnculo 2-8 cm compr., glomérulo 1,5-2 $\times$ $1-1,5 \mathrm{~cm}$, brácteas externas 4-6, lanceoladas, 15-18 mm compr., agudas ou acuminadas. Flores sésseis; cálice 2,5-3 $\mathrm{mm}$ compr., denteado; corola tubular, alva, arroxeadas, creme ou roxo, externamente levemente pilosa ou glabrescente, tubo 10-15 mm compr., lobos ca. 1,5 mm compr. Drupas elipsóides, ca. $5 \times$ $4 \mathrm{~mm}$, azuis ou lilases; pirênios 2 , hemisféricos, com 3-5 costas longitudinais.

Ocorre apenas nos arredores de Manaus. Foi originalmente descrita a partir de um material da Reserva Ducke. Campos \& Brito (1999: pág. $627,634,635$ ) observaram que os tricomas desta espécie são frequentemente arroxeados, enquanto Kinupp (2002: fig. 14a, b, c) registrou 
a espécie como amplamente distribuída dentro da Reserva, sendo mais comum na foresta de platô. Foi coletada com flores em setembro e dezembro, e com frutos de fevereiro a maio. 9.XII.1994 (fl) Costa \& Nascimento 40 (INPA MO SPF); 6.XII.1995 (fl) Sothers 698 (INPA MO SPF); 8.IX.1994 (fl) Assunção 68 (INPAMO SPF); 8. II.1996 (fr) Campos et al. 462 (INPAMO SPF), 8.IV.1995 (fr) Costa \& Sothers 171 (INPAMO SPF); 18.V.1988 (fr) Coêlho 64 (INPA MO SPF); 21.III.1995 (fr) Sothers et al. 350 (INPA MO SPF); 18.III.1996 (fr) Campos \& Pereira 551 (INPA MO SPF), 9.IV.1995 (fr) Costa et al. 188 (INPA MO SPF); 9.III.1994 (fr) Ribeiro et al. 1218 (INPA MO SPF).

27.22 Psychotria rhombibractea C. M. Taylor \& M. T. Campos, Novon 9: 118, fig. 1. 1999.

Arvoretas ou arbustos até $5 \mathrm{~m}$ alt., ca. $2 \mathrm{~cm}$ diâm. Tronco cilíndrico, de base reta. Ritidoma marrom-escuro; exterior da casca marrom-escuro; casca internamente creme, fibrosa; alburno creme. Ramos cilíndricos, glabros. Estípulas unidas ao redor do caule, glabras, persistentes, bainha $0,5-1 \mathrm{~mm}$ compr., truncada ou em forma de $U$, lobos 2 de cada lado, deltóides, 0,5-1 mm compr. Folhas opostas, pecioladas; pecíolo 0,5-1,5 cm compr.; lâmina elíptica, 7-18 $\times 2-7 \mathrm{~cm}$, ápice acuminado a longo acuminado, base cuneada ou aguda, papirácea, glabra; nervuras laterais 6-10 pares, planas ou ligeiramente espessadas em ambas as faces. Inflorescências terminais, glabras, cimosas, corimbiformes, pedúnculo 8-20 mm compr., panícula 1-1,5×2-4cm, congesta, com 1-3 pares de ramos secundários, brácteas alvas, elípticas, estreitamente elípticas, oblanceoladas ou usualmente rômbicas, 3-10 mm compr., obtusas ou agudas. Flores sésseis em címulas 5-7-floras; cálice 0,2-0,5 mm compr., denteado, pubérulo; corola estreitamente infundibuliforme, alva, glabra externamente, tubo 9-10 mm compr., lobos 5$6 \mathrm{~mm}$ compr. Infrutescências com brácteas vináceas, avermelhadas ou alaranjadas. Drupas subglobosas, ligeiramente bilobadas, 4-6×6-8 $\mathrm{mm}$, avermelhadas, vináceas ou arroxeadas; pirênios 2, hemisféricos, lisos.

É conhecida somente da região de Manaus. Tanto Taylor \& Campos (1999) como Kinupp (2002: fig. 14d) observaram que é uma espécie amplamente distribuída dentro da Reserva Ducke. Brito \& Campos (1999: pág. 627, 637) identificaram a maioria dos espécimes da Reserva corretamente, porém, em uma instância, usaram erroneamente o nome $P$. casiquiaria Müll. Arg. (p. 636), que havia sido utilizado nas determinações provisórias do material da reserva, e provavelmente permaneceu no banco de dados quando a maioria dos registros foi re-identificada como $P$. rhombibractea. Na Reserva, foi coletada em floresta de platô, com flores em setembro e novembro, com frutos de fevereiro a abril, junho e agosto. Nome vulgar: "mata-calado".

23.VIII.1994 (fr) Sothers \& Silva 124 (INPA MO SPF), 6.III.1996 (fr) Campos \& Pereira 536 (INPA MO SPF); 8.II.1996 (fr) Campos et al. 461 (INPA); 28.IX.1994 (fl) Hopkins et al. 1483 (INPAMO type); 9.VI.1963 (fr) Rodrigues \& Freitas 5322 (INPANY); 6.XI.1961 (fl) Rodrigues \& Lima 3534 (INPA NY); 25.X.1977 (fr) Keel 189(NY); 11.III.1994 (fr) Vicentini \& Silva 418 (INPA MO SPF); 12.XI.1993 (fl) Vicentini \& Assunção 372 (INPA MO SPF); 5.VI.1963 (fr) Rodrigues 5254 (INPANY); 18.III.1991 (fr) Mota \& Santana 3 (INPA MO); IV.1973 (fr) Rodriguez \& Silva 9110 (INPAMO); 14.VI.1994 (fr) Ramos 2826 (INPAMO SPF); 29.III.1996 (fr) Campos \& Silva 586 (INPA MO SPF); XII.1997 (fr) Martins et al. 61 (INPA MO), 62 (INPAMO).

27.23 Psychotria sphaerocephala Müll. Arg., Flora 59: 550. 1876.

Subarbustos ou ervas até $2 \mathrm{~m}$ alt., ca. $3 \mathrm{~cm}$ diâm. Ramos cilíndricos, densamente hirtelos ou pilosos. Estípulas unidas ao redor do caule ou quase interpeciolares, hirtelas ou pilosas, persistentes, 1,5-4 $\mathrm{mm}$ compr., laceradas, cada lado com vários lobos. Folhas opostas, pecioladas; pecíolo 3-5 mm compr.; lâmina elíptica, 6,5-11 × 2,5-5 cm, ápice acuminado, base cuneada ou obtusa, papirácea, curtamente pilosa; nervuras laterais 14-17 pares, impressas na face adaxial, salientes na face abaxial. Inflorescências terminais, capitadas, hirtelas, pedúnculo $2,5-4,5 \mathrm{~cm}$ compr., glomérulo 6-10 mm diâm., sem brácteas involucrais. Flores sésseis; cálice 2,5-3 mm compr., denteado; corola infundibuliforme, alva, externamente glabra, tubo 3,5-4 mm compr., 
lobos ca. $1 \mathrm{~mm}$ compr. Drupas subglobosas, 2,53,5 mm diâm., azuis; pirênios 2, hemisféricos, com 3-5 costas longitudinais.

Ocorre na Venezuela e na amazônia brasileira, e foi estudada por Kinupp (2002, fig. 15c, d, fig. 16a). Na Reserva, foi coletada apenas com frutos, em junho (Campos \& Brito 1999: pág. 635). 20.VI.1993 (fr) Ribeiro et al. 942 (INPA).

27.24 Psychotria stipulosa Müll. Arg., Fl. bras. 6(5): 334. 1881.

Arbustos ou subarbustos até $2 \mathrm{~m}$ alt. Ramos ligeiramente quadrangulares ou cilíndricos, glabros. Estípulas interpeciolares ou brevemente unidas ao redor do caule, glabras, persistentes, ovadas, bainha 5-10 mm compr., lobos 2 de cada lado, agudos, 5-10 mm compr. Folhas pecioladas; pecíolo 0,5-4 cm compr.; lâmina elíptica ou elíptico-oblonga, 13-28 ×4$9 \mathrm{~cm}$, ápice agudo, base cuneada, papirácea, glabra; nervuras laterais 20-26 pares, ligeiramente salientes na face adaxial, salientes na face abaxial. Inflorescências terminais, subglobosos, subcapitadas ou congestocimosas, glabras, pedúnculo 1-6 cm compr., glomérulo ou panícula 2,5-4,5 × 2,5-6 cm, brácteas elípticas, 8-25 mm compr. Flores sésseis; cálice ca. 0,8 mm compr., subtruncado ou denteado; corola infundibuliforme, alva, glabra externamente, tubo 8-11 mm compr., lobos 3,5-4 mm compr. Drupas elipsóides, ca. 4,5 × 4,5 mm, azuis ou negras; pirênios 2, hemisféricos, com 3-5 costas longitudinais.

Ocorre na Venezuela, Colômbia e na amazônia brasileira, e foi registrada pela primeira vez na Reserva Ducke por Kinupp (2002), sendo que sua distribuição foi estudada por Kinupp (2002) e Kinupp \& Magnusson (2005). Na Reserva, foi coletada em floresta de platô e de transição baixio-vertente, apenas com frutos, em maio (Kinupp 2002).

2001, Кinupp 1771 (INPA).

27.25 Psychotria subundulata Benth., J. Bot. (Hooker) 3: 227. 1841.

Arvoretas até $5 \mathrm{~m}$ alt. Tronco cilíndrico, base reta. Ritidoma verde ou marrom-acinzentado com estrias longitudinais de desprendimento em escamas, lenticelas pequenas; exterior da casca marrom-acinzentada, ca. $1 \mathrm{~mm}$ espessura; casca internamente marrom com estrias alvas, fibrosa; alburno creme. Ramos quadrangulares ou cilíndricos, glabros. Estípulas unidas ao redor do caule, glabras, persistentes, bainha $0,5-1,5 \mathrm{~mm}$ compr., truncada ou em forma de $U$, lobos 2 de cada lado, deltóides ou triangulares, 1-1,5 mm compr. Folhas opostas, pecioladas; pecíolo 0,5$2 \mathrm{~cm}$ compr., pubérulo ou glabro; lâmina elíptica, 12-23 × 3,5-11 cm, ápice acuminado, base cuneada ou aguda, papirácea, glabra na face adaxial, pubérula na face abaxial; nervuras laterais 11-13 pares, planas na face adaxial, salientes na face abaxial. Inflorescências terminais, piramidais, pubérulas, paniculadas, pedúnculo 5-7 cm compr., porção ramificada 4,5-7 ×4$8 \mathrm{~cm}$, ebracteada ou as brácteas reduzidas. Flores subsésseis, agrupadas em címulas dicotômicas; cálice 0,2-0,3 mm compr., denteado, pubérulo; corola infundibuliforme, branco-amarelada, externamente glabra, tubo 2-3 mm compr., lobos ca. 1,5 mm compr. Drupas subglobosas, ca. $2 \times 3 \mathrm{~mm}$; pirênios não observados.

Ocorre na Venezuela, Guianas, Equador, Colômbia e na amazônia brasileira. Ver comentários acima, sob Psychotria paniculata. $\mathrm{Na}$ Reserva, foi coletada nos baixios, com flores em janeiro e com frutos em março (Campos \& Brito 1999: pág. 637; Kinupp 2002: fig, 16b, c). 6.III.1997 (fl) Assunção \& Pereira 483 (INPA MO SPF); 28.I.1998 (fl) Brito \& Assunção 51 (INPA MO); 22.III.1996 (fr) Campos et al. 574 (INPA MO SPF); 2001, Kinupp 1843 (INPA), 1845 (INPA).

27.26 Psychotria trichocephala Poepp. \& Endl., Nov. Gen. Sp. P1. 3: 32, t. 238. 1845.

Psychotria medusula Müll. Arg., Flora 59: 541. 1876, syn. nov.

Ervas prostradas ou subarbustos até $8 \mathrm{~cm}$ alt. Ramos cilíndricos, hirtelos ou pilosos. Estípulas unidas ao redor do caule, hirtelas ou pilosas, persistentes, bainha 1-2 mm compr., truncada ou em forma de $U$, lobos 2 de cada lado, triangulares, 4-5 mm compr., ciliados. Folhas opostas, pecioladas; pecíolo 0,5-1 cm compr.; lâmina elíptica, 6-12,5 × 1,5-4,5 cm, ápice 
acuminado, base cuneada, papirácea, glabra na face adaxial, glabra ou esparsamente pilosa na face abaxial, margens ciliadas; nervuras laterais 6-10 pares, planas em ambas as faces. Inflorescências terminais, subcapitadas, hirsutas ou hirtelas, pedúnculo 5-10 mm compr., panícula 1-2 × 1-2,5 cm, com brácteas lineares, cobertas por abundantes tricomas escuros nos espécimes herborizados, 8-15 mm compr. Flores sésseis em glomérulos 2-3-floros; cálice ca. 0,5 mm compr., denteado; corola tubular, alva, externamente glabra, tubo 1,1-1,3 cm compr., lobos 2-3 mm compr. Drupas elipsóides, 56 mm diâm., arroxeadas ou azuis; pirênios 2 , hemisféricos, com 3-5 costas longitudinais.

Ocorre na Colômbia, Peru e no Brasil, nos estados da região amazônica. No Guia de Campo, esta espécie foi inicialmente identificada sob o nome Psychotria medusula (Campos \& Brito 1999: pág. 627, 634; Kinupp 2002: fig. 4c, fig. 11a, b), porém um estudo mais detalhado mostrou que $P$. trichocephala tem prioridade sobre $P$. medusula. Na Reserva, foi coletada em diferentes habitats, com flores em outubro e com frutos em março e abril.

21.III.1995 (fr) Sothers et al. 352 (INPA); 9.IV.1995

(fr) Costa et al. 184 (INPA MO); 19.III.1996 (fr)

Campos et al. 557 (INPA MO); 31.X.1995 (fl)

Sothers \& Silva 661 (INPA MO); 12.X.1994 (fl) Vicentini \& Pereira 736 (INPA MO).

27.27 Psychotria turbinella Müll. Arg., Fl. bras. 6(5): 374. 1881.

Fig. 3d

Arbustos ou subarbustos até $1 \mathrm{~m}$ alt. Ramos cilíndricos, glabros. Estípulas unidas ao redor do caule, glabras, persistentes, bainha ca. $1 \mathrm{~mm}$ compr., lobos 2 de cada lado, estreitamente triangulares, 3-6 mm compr. Folhas opostas, pecioladas; pecíolo 3-7 mm compr.; lâmina elíptica ou oblanceolada, 7-16×3-7 cm, ápice agudo ou curto-acuminado, base cuneada, papirácea, glabra; nervuras laterais 12-14 pares, planas ou impressas na face adaxial, ligeiramente salientes na face abaxial. Inflorescências terminais, capitadas, glabras, verdes na base, pedúnculo 1-1,5 cm compr., glomérulo 1-1,5 × 2-3 cm, brácteas externas 4, elípticas, 0,6-1,5 cm compr., obtusas. Flores sésseis; cálice 0,8-1 mm compr., denteado; corola tubular, alva, externamente glabra, tubo ca. $5 \mathrm{~mm}$ compr., lobos ca. $2 \mathrm{~mm}$ compr. Drupas elipsóides, ca. $5 \times 3,5 \mathrm{~mm}$, lilases; pirênios 2 , hemisféricos, com 3-5 costas longitudinais.

Ocorre apenas nas proximidades de Manaus, tendo sido registrada na Reserva a partir de uma coleta estéril por Kinupp (2002, fig. 17), e posteriormente por Kinupp \& Magnusson (2005). Steyermark (1972) reconhece duas variedades para a espécie, sendo que a variedade típica possui folhas geralmente glabras e ocorre no Leste do Brasil, enquanto que a var. sororiella (Müll. Arg.) Steyerm. possui folhas, ramos e estípulas com pilosidade hirta, ocorrendo na Venezuela, Bolivia e oeste do Brasil. As plantas que ocorrem na reserva encaixam-se na descrição da var. sororiella, enquanto espécimes pertencendo à var. turbinella também foram coletados nas proximidades de Manaus.

1963, A. Castellanos s.n. (INPA-27590).

Material adicional examinado: BRASIL. AMAZONAS: Manaus, Distrito Agropecuário, Res. 1501 (km 41), 2²4'26”- 2²5'31'"S, 5943'40”59॰45' 50” W, 50-125 m, 11.I.1989 (fl) Pacheco et al. 109 (INPA K).

27.28 Psychotria variegata Steyerm., Mem. New York Bot. Gard. 23: 638. 1972.

Ervas prostradas. Ramos cilíndricos, pilosos ou hirsutos. Estípulas unidas ao redor do caule ou quase interpeciolares, pilosas ou hirsutas, persistentes, bainha 2-3 mm compr., lobos 2 de cada lado, estreitamente triangulares ou lineares, 3-5 mm compr. Folhas opostas, pecioladas; pecíolo 0,3-1 cm compr.; lâmina lanceolada ou ovada, 2,5-6 × 1-3 cm, ápice obtuso ou agudo, base truncada ou subcordada, papirácea, hirsuta ou pilosa; nervuras laterais 9-14 pares, planas em ambas as faces. Inflorescências terminais, capitadas, pilosas ou hirtelas, verdes, pedúnculo 4-15 mm compr., glomérulo 0,8-1 ×1-2 cm, brácteas lanceoladas ou triangulares, 6-9 mm compr., agudas. Flores sésseis; cálice 1,2-1,5 mm compr., denteado; corola tubular, alva ou amarela, externamente levemente pilosa ou glabrescente, tubo 5-7 mm compr., lobos 2-2,5 mm compr. Drupas 
subglobosas, 4-7×2-7 mm, azuis; pirênios 2, hemisféricos, lisos.

Ocorre nas Guianas, Brasil e Bolívia. Registrada pela primeira vez na Reserva Ducke por Kinupp (2002: fig. 4a, fig. 18), que frisou a existência de dois morfotipos já observados por outros autores (Steyermark 1972): o morfotipo "não variegado", com folhas arroxeadas na face inferior e uniformemente verdes na face superior, e o morfotipo "variegado", cujas folhas são verdes na face inferior e verde-escuras com uma estria mais clara ao longo da face superior. Kinupp (2002) sugere que estes morfotipos podem estar associados aos diferentes microhabitats ocupados pela espécie. Na Reserva, foi coletada com flores em janeiro e fevereiro e com frutos em março (Kinupp 2002).

2001, Кіпирр 1633 (INPA), 1687 (INPA), 1987 (INPA), 2002 (INPA).

\section{Remijia DC.}

Árvores ou arbustos hermafroditas. Ramos geralmente quadrangulares, às vezes com exsudado resinoso, ocasionalmente com formigas, usualmente espessados. Estípulas interpeciolares, triangulares ou elípticas, conspícuas, decíduas. Folhas opostas ou verticiladas, sésseis ou pecioladas, decussadas, ocasionalmente com domácias, freqüentemente bem desenvolvidas. Inflorescências axilares, subcapitadas, cimosas, paniculadas ou tirsóides. Flores bissexuais, fragrantes, geralmente distílicas; cálice truncado, espatáceo ou geralmente 4-6-denteado; corola salverforme, alva ou rosada, 4-6-lobada, prefloração valvar; estames 4-6, inseridos no tubo da corola, anteras dorsifixas, inclusas ou exsertas; ovário 2-locular, óvulos muitos por lóculo; estigma inteiro ou 2partido. Frutos capsulares, cilíndricos ou oblongos, cartáceos ou lenhosos, deiscência septicida, as valvas às vezes bífidas no ápice; sementes numerosas, irregularmente elípticas, aplanadas, aladas.

Compreende cerca de 45 espécies distribuídas na América do Sul, principalmente no Brasil, Venezuela, Colômbia, Equador, Bolívia e Peru (Taylor et al. 2004). São características deste gênero as folhas geralmente verticiladas e bem desenvolvidas, as estípulas conspícuas e geralmente eretas, as inflorescências axilares e os frutos capsulares com sementes aladas.

\section{Chave para as espécies de Remijia na Reserva Ducke}

1. Folhas com lâmina $35-42 \times 7-8 \mathrm{~cm}$; estípulas $3-3,5 \mathrm{~cm}$ compr. 1. R. amazonica

1'. Folhas com lâmina $75-90 \times 25-27 \mathrm{~cm}$; estípulas 9-12 cm compr. 2. R. ulei

28.1 Remijia amazonica K. Schum., Fl. bras. 6(6): 153.1889.

Fig. 3e

Arbustos ou arvoretas até $7 \mathrm{~m}$ alt., ca. $9 \mathrm{~cm}$ diâm. Tronco acanalado. Ritidoma marrom, liso ou reticulado em alguns pontos; exterior da casca marrom, ca. 0,5 $\mathrm{mm}$ de espessura; casca internamente bege com estrias marrons; alburno bege; exsudato hialino, avermelhado, escasso. Ramos ligeiramente quadrangulares, ferrugíneos, tomentosos, fistulosos, resinosos no ápice (i.e., "com látex" de Campos \& Brito 1999). Estípulas triangulares a lanceoladas, $3-3,5 \times 1-1,5 \mathrm{~cm}$, externamente tomentosas, internamente glabras. Folhas 3-4-verticiladas; pecíolo 1-2 cm compr.; lâmina estreito-lanceolada, $35-42 \times 7-8 \mathrm{~cm}$, ápice acuminado, base decurrente, coriácea, glabra a esparsamente pubérula na face adaxial, pubérula na face abaxial; nervuras laterais 21-25 pares, com domácias pubescentes nas axilas abaxiais. Inflorescências paniculadas ou espiciformes, multifloras, 31-38 × 1-3 cm, pedunculadas. Flores sésseis; cálice curtamente 5-denteado, ca. $1 \times 1 \mathrm{~mm}$, tomentoso; corola creme, tomentosa, 1-2 $\times 1 \mathrm{~cm}, 5$-lobada; estames 5. Cápsulas oblongas, esparsamente pubérulas, 2,5-3,5 ×5$8 \mathrm{~mm}$; sementes ca. $15 \times 2-5 \mathrm{~mm}$.

Ocorre na região amazônica da Venezuela, Bolívia e Brasil. Na Reserva Ducke, ocorre em floresta vertente e campinarana. Floresce em março e frutifica em agosto (Campos \& Brito 1999: pág. 627, 633). 
25.VIII.1994 (fr) Sothers 144 (INPANY); 12. III.1996 (fl) Campos \& Silva 542 (INPA MO NY SPF).

Material adicional examinado: BRASIL. AMAZONAS: Manaus, Estrada da Raiz, 19.V.1936, Ducke 194 (IAN K).

28.2 Remijia ulei K. Krause, Notizbl. Bot. Gart. Berlin-Dahlem 6: 201. 1914.

Árvores ou arvoretas até $3 \mathrm{~m}$ alt., ca. 8 $\mathrm{cm}$ diâm. Tronco irregular, com pequenas raízes tabulares. Ritidoma marrom-claro, escamoso; lenticelas salientes, circulares, dispersas pelo tronco; exterior da casca fina; casca rosada internamente; exsudato alaranjado ou transparente, pegajoso, escasso; alburno branco. Ramos quadrangulares, fistulosos, ferrugíneotomentosos, glabrescentes. Estípulas triangulares, 9-12 × 2,5-4 cm, esparsamente pubérulas. Folhas 3-4-verticiladas; pecíolo 1-2 cm compr.; lâmina lanceolada a estreito-lanceolada, 75-90 $\times 25-27 \mathrm{~cm}$, esparsamente pubérula na face adaxial, pubérula na face abaxial, tomentosa nas nervuras, ápice acuminado, base decurrente; nervuras laterais 20-22 pares. Inflorescências em panículas multifloras, seríceas, $23-47 \times 5-$ $7 \mathrm{~cm}$. Flores sésseis; cálice 5-lobado, lobos curto-denteados, seríceos, 3-4 × 3-4 mm; corola creme, serícea, $1,5-2 \times 0,2-0,3 \mathrm{~cm}, 5-$ lobada. Cápsulas oblongas, esparsamente pubérulas, glabrescentes, 5-6,5 × 1-1,5 cm; sementes $1,5-2 \mathrm{~cm}$.

Ocorre amplamente nas florestas tropicais do Peru, Equador, Venezuela e Brasil. Apresenta associação com formigas que habitam seus ramos fistulosos. Na Reserva, foi coletada na floresta de baixio e de vertente, com flores em novembro e frutos em janeiro (Campos \& Brito 1999: pág. 627, 633).

4.IX.1962 (est) A.P. Duarte 6944 (K RB); 1.XI.1994, (fl) Vicentini et al. 759 (INPA K MO NY SPF); 24.I.1995 (fr) Nascimento \& Silva 713 (INPANY).

\section{Ronabea Aubl.}

Arbustos hermafroditas. Ramos cilíndricos ou quadrangulares. Estípulas interpeciolares ou curto-unidas ao redor do caule, triangulares ou subuladas, persistentes. Folhas opostas, decussadas, pecioladas. Inflorescências axilares, capitadas ou subcapitadas. Flores bissexuais, distílicas; cálice subtruncado a 5denteado; corola hipocrateriforme, alva, no interior pubescente na porção mediana do tubo, 5-lobada, prefloração valvar; estames 5, inseridos na porção mediana a superior do tubo da corola, anteras dorsifixas, inclusas; ovário 2-locular, óvulos 1 por lóculo; estigma 2-partido. Frutos drupáceos, elipsóides, carnosos, negros ou azuis; pirênios 2, plano-convexos, 1-loculares.

Compreende três espécies tropicais da América Central e do Sul (Taylor 2004), com apenas uma espécie na Reserva Ducke. No Guia de Campo (Campos \& Brito 1999), esta espécie foi listada dentro de Psychotria porém estudos moleculares e morfológicos evidenciaram que Ronabea trata-se de um gênero à parte (Taylor 2004), cujas características morfológicas são as inflorescências axilares e as estípulas estreitamente triangulares.

29.1 Ronabea latifolia Aubl., Hist. Pl. Guiane 1: 154, t. 59. $1775 . \quad$ Fig. 3f

Ronabea erecta Aubl., Hist. Pl. Guiane 1:154. 1775.

Psychotria axillaris Willd., Sp.Pl. 1:962. 1798.

Psychotria erecta (Aubl.) Standl. \& Steyerm., Publ. Field Mus. Nat. Hist., Bot. Ser. 23: 24. 1943.

Arvoretas até $4,5 \mathrm{~m}$ alt. Ramos cilíndricos ou quadrangulares, puberulentos ou glabros. Estípulas interpeciolares, glabras ou pubérulas, 2-6 $\mathrm{mm}$ compr., triangulares, agudas. Folhas pecioladas; pecíolo $8-20 \mathrm{~mm}$ compr.; lâmina elíptica, 8-20 × 3-9 cm, ápice acuminado, base cuneada ou aguda, papirácea, glabrescente; nervuras laterais 5-8 pares. Inflorescências subcapitadas, glabras ou pubérulas, pedúnculos e pedicelos 0-1 cm compr., brácteas reduzidas. Flores com cálice ca. $1 \mathrm{~mm}$ compr., subtruncado; corola salverforme, alva, externamente glabra, tubo 3-4 $\mathrm{mm}$ compr., lobos 1,5-3 mm compr. Drupas elipsóides, $8-10 \times 5-8 \mathrm{~mm}$, azuladas a enegrecidas; pirênios lisos.

Ocorre da América Central, Bolívia e Brasil, nos estados da região amazônica. $\mathrm{Na}$ Reserva, foi coletada na floresta de baixio, 
apenas com frutos em fevereiro (Campos \& Brito 1999: pág. 644, sob Psychotria erecta). 10.II.1996 (fr) Campos et al. 478 (INPA K MO SPF).

\section{Rudgea Salisb.}

Arvoretas ou árvores hermafroditas. Ramos geralmente cilíndricos. Estípulas interpeciolares, persistentes ou às vezes decíduas, freqüentemente laciniadas ou setosas, com apêndices aristados, às vezes glandulares, raramente inteiras, freqüientemente decíduas. Folhas opostas, decussadas, subsésseis ou pecioladas. Inflorescências terminais, paniculadas, cimosas, umbeladas ou capitadas. Flores bissexuais, geralmente distílicas, odoríferas; cálice subtruncado ou 4-6-lobado; corola tubulosa ou infundibuliforme, alva a amarela, internamente glabra até pubescente, 4-6-lobada, prefloração valvar, lobos da corola frequentemente corniculados; estames 4-6, inseridos na porção mediana a superior do tubo da corola, anteras dorsifixas, inclusas ou exsertas; ovário 2-locular, óvulos 1 por lóculo; estigma 2-partido. Frutos drupáceos, elipsóides ou subglobosos, carnosos ou esponjosos, alvos, amarelos, vermelhos, arroxeados, negros, raramente azulados; pirênios 2, plano-convexos, geralmente costados, 1-loculares.

Este gênero neotropical compreende cerca de 160 espécies que ocorrem no México, América Central e América do Sul tropical (Taylor et al. 2004). É semelhante à Psychotria subg. Heteropsychotria, do qual se distingue pelas estípulas nunca bilobadas, frequentemente laciniadas, apendiculadas ou aristadas (Taylor \& Zappi 2006).

\section{Chave para as espécies de Rudgea na Reserva Ducke}

1. Estípulas 10-22 mm compr., profundamente laciniadas, os lobos persistentes, não glandulares; lâmina foliar $24-30 \mathrm{~cm}$ compr. 2. R. lanceifolia

1'. Estípulas 2-6 mm compr., triangulares, com apêndices decíduos, curtos e glandulares no ápice; lâmina foliar 8,5-14 cm compr. 1. R. gracilliflora

30.1 Rudgea gracilliflora Standl., Field. Mus. Nat. Hist., Bot. Ser. 11: 262. $1936 . \quad$ Fig. 3g Árvores até $10-17$ m alt., $10-12 \mathrm{~cm}$ diâm. Tronco cilíndrico, base acanalada, levemente tortuosa na base. Ritidoma marrom ou marromacintenzado, com fissuras horizontais; exterior da casca fina, ca. $0,5 \mathrm{~mm}$ de espessura; casca internamente alvo-amarelada ou amareloalaranjada; alburno alvo-esverdeado, avermelhado quando oxidado. Estípulas triangulares a arredondadas, 2-6 $\times 2-5 \mathrm{~mm}$, glabras, com apêndices decíduos glabros na face adaxial. Folhas pecioladas; pecíolo 1-1,5 cm compr., glabro; lâmina elíptica a estreito-lanceolada, 8,5$14 \times 4,5-7,5 \mathrm{~cm}$, ápice acuminado, base obtusa, glabra em ambas as faces; nervuras laterais 67 pares, impressas na face adaxial, salientes na face abaxial. Inflorescências subcapitadas ou curto-cimosas, $10-12,5 \mathrm{~cm}$ compr. pedunculadas. Flores sésseis, distílicas; cálice 1-1,5×1 mm, glabro, 5-denteado; corola alva, glabra, tubo $7-$ $9,5 \times 2-4 \mathrm{~mm}, 5$-lobada, lobos da corola corniculados; anteras amareladas; estigma alvo. Drupas elipsóides, ca. $1 \times 0,7-0,8 \mathrm{~cm}$, vermelhas, passando a castanhas quando maduras, carnosas.

Ocorre no Equador, Peru, Bolívia, Venezuela, Guianas e norte e noroeste do Brasil. Na Reserva, foi coletada na floresta de vertente e platô, com flores em setembro (Campos \& Brito 1999: pág. 641 como "Rudgea graciliflora"; e 647 como "Rudgea gracilenta" - foto do tronco). 12.IX.1996 (fl) Assunção et al. 387 (INPA K MO SPF), 13.IX.1996 (fl) Assunção \& Pereira 393 (INPA KMO SPF).

30.2 Rudgea lanceifolia Salisb., Trans. Linn.

Soc. London 8: 327, t. 18. 1807.

Rudgea fissistipula Müll. Arg., Flora 59: 449, 460. 1876.

Rudgea prancei Steyerm., Brittonia 33(3): 358. 1981. Syn. nov.

Arvoretas até 5,5 m alt., ca. $10 \mathrm{~cm}$ diâm. Tronco circular, base reta. Ritidoma marromclaro; exterior da casca marrom, ca. $1 \mathrm{~mm}$ 
espessura; casca internamente bege, ca. $3 \mathrm{~mm}$ de espessura; alburno amarelo-claro. Ramos cilíndricos ou ligeiramente quadrangulares, glabros. Estípulas profundamente laciniadas, 1$2,2 \times 0,8-1 \mathrm{~cm}$, decíduas. Folhas pecioladas; pecíolo 1,5-2 cm compr., glabro; lâmina lanceolada ou estreito-elíptica, 24-30 ×7,5-10,5 $\mathrm{cm}$, ápice acuminado, base aguda, subcoriácea, glabra em ambas as faces; nervuras laterais 911 pares, impressas na face adaxial, salientes na face abaxial. Inflorescências subcapitadas ou curto-3-ramificadas, multifloras, 5-7 cm compr., curto-pedunculadas. Flores sésseis; cálice ca. $5 \mathrm{~mm}$ compr., 5-denteado; corola alvoesverdeada, externamente tomentosa, 8-9,7 cm compr., tubo 2-3 mm diâm., 5-lobada. Drupas alaranjadas, 3-3,8 × 1,7-2,5 cm, glabras.

Ocorre na Guiana Francesa, Guiana, Venezuela, Peru e amazônia brasileira. Foi inicialmente determinada como $R$. fissistipula (Campos \& Britto 1999), porém estudos recentes (Taylor et al. 2004) comprovam que tanto $R$. fissistipula como $R$. prancei não possuem características que possibilitem sua separação de $R$. lanceifolia, a espécie-tipo do gênero. O espécime coletado por Rodrigues \& Osmarino 5719 foi previamente identificado como Rudgea krukovii Standl., mas deve ser incluído como $R$. cf. lanceifolia, ainda necessitando confirmação. Na Reserva Ducke, $R$. lanceifolia ocorre em floresta de platô, foi coletada em flor em fevereiro e setembro e em fruto no mês de fevereiro (Campos \& Brito 1999: pág. 627, 647).

14.II.1996 (fr) Campos et al. 491 (INPA MO NY SPF); 14.IX.1971 (fl) Prance et al. 14739 (MO NY; material-tipo de Rudgea prancei); 25.II.1964 (fl) W. Rodrigues \& Osmarino 5719 (INPA).

\section{Sabicea Aubl.}

Lianas herbáceas ou arbustos com ramos escandentes ou raramente eretos, hermafroditas. Ramos cilíndricos. Estípulas interpeciolares, eretas ou geralmente reflexas com a idade, ovais a liguladas, persistentes. Folhas opostas ou verticiladas, decussadas, pecioladas. Inflorescências axilares, corimbosas, glomerulares ou capitadas. Flores bissexuais, geralmente distílicas; cálice 5-lobado; corola hipocrateriforme ou infundibuliforme, geralmente alva, pubescente na região da fauce, 5-lobada, prefloração valvar; estames 5, inseridos no tubo ou na fauce da corola, anteras dorsifixas; ovário 5-locular, óvulos muitos por lóculo; estigma 5-partido. Frutos bacáceos, globosos, carnosos, rubros, arroxeados ou negros; sementes numerosas, ovais ou angulosas.

Ocorre na América tropical, África tropical e Madagascar, com cerca de 130 das quais cerca de 60 ocorrem na América (Taylor et al. 2004). O hábito escandente, as estípulas persistentes geralmente recurvadas e os frutos bacáceos são características deste gênero. Sabicea pode ser confundida com Malanea, porém este último têm frutos drupáceos paucisseminados e nervação terciária das folhas paralela.

31.1 Sabicea amazonensis Wernh., Monogr. Sabicea 47, t. 5, figs. 3, 4. 1914 Fig. 3h

Lianas herbáceas. Ramos cilíndricos, delgados, densamente hirsutos e com tricomas aracnóides e às vezes arroxeados. Estípulas membranáceas, deltóides, recurvadas, 6-10× 6-10 mm, externamente glabras, internamente hirsutas. Folhas dísticas, discolores, pecioladas; pecíolo 4-10 mm compr., hirsuto; lâmina oblanceolada, oblonga ou elíptica, 6,4-10,5 $\times$ 2,6-4,5 cm, ápice acuminado, base obtusa, densamente hirsutas principalmente nas nervuras em ambas as faces, abaxialmente esbranquiçada com tricomas aracnóides e às vezes arroxeados; nervuras laterais 16-18 pares. Inflorescências glomerulares, 4-5-floras, subsésseis, protegidas por brácteas hirsutas, semelhantes às estípulas. Flores sésseis; cálice 1,5-2 × 3-4 mm, hirsuto, lobos triangulares; corola alva, 3-3,5 × 1,5-2 cm, externamente hirsuta, lobos triangulares. Bagas avermelhadas, 2,5-3 × 9-13 $\mathrm{mm}$, hirsutas.

Ocorre no Peru, Venezuela e no Brasil, nos estados do Amazonas, Pará, Amapá e Mato Grosso. É facilmente reconhecível por ser uma liana herbácea, com folhas discolores, estípulas recurvadas, e bagas multisseminadas. $\mathrm{Na}$ Reserva Ducke, ocorre preferencialmente em 
áreas perturbadas como capoeiras e clareiras; floresce de fevereiro a abril e frutifica em março e abril. Campos \& Brito (1999: pág. 627, 628). 3.II.1995 (fl) Costa \& Nascimento 136 (INPA NY); 10.IV.1995 (fl fr) Costa et al. 207 (INPA K MO NY SPF); 1.II.1994 (fl) Assunção 106 (INPA NY SPF); 27.III.1996 (fl fr) Sothers \& Silva 840 (MO SPF).

\section{Schradera Vahl.}

Arbustos epifíticos ou lianas lenhosas, hermafroditas, suculentos. Ramos cilíndricos. Estípulas interpeciolares ou unidas ao redor do caule, obovadas a oblongas, decíduas. Folhas opostas, pecioladas, decussadas. Inflorescências terminais, capitadas com brácteas involucrais. Flores bissexuais, freqüentemente distílicas, fragrantes, noturnas; cálice truncado ou sinuoso; corola salverforme, alva, carnosa, glabra ou na região da fauce vilosa, 5-6-lobada, prefloração valvar; estames 5-6, inseridos no tubo da corola, antera dorsifixas; ovário 2(-4)-locular, óvulos muitos por lóculo; estigma 2-partido. Frutos bacáceos, globosos ou elipsóides, carnosos, verde claros a amarelados; sementes numerosas, suborbiculares, comprimidas.

Compreende cerca de 65 espécies as quais ocorrem no Caribe, América Central e América do Sul, Sudoeste da Ásia e Nova Guiné (Puff et al. 1993; Taylor et al. 2004). É caracterizado pelo hábito escandente suculento, as inflorescências capitadas com invólucro na forma de um anel truncado, as flores alvas, noturnas e carnosas e os frutos bacáceos. Os espécimes apresentam dimorfismo entre ramos jovens, com raízes adventícias e folhas relativamente pequenas, e ramos reprodutivos, com folhas maiores e suculentas e desprovidos de raízes adventícias.

\subsection{Schradera polycephala DC., Prodr. 4:} 444. 1830.

Fig. 3i

Lianas lenhosas. Tronco acanalado. Ritidoma marrom-avermelhado, fissurado, rígido, com desprendimento pulverulento; exterior da casca marrom-avermelhada; casca internamente vermelha, ca. $1 \mathrm{~mm}$ de espessura; alburno creme com faixas longitudinais marrons, odor suave. Ramos cilíndricos, glabros, fistulosos. Estípulas obovadas a oblanceoladas, 1,7-1,9× 4-6 mm, glabras. Folhas coriáceas, pecioladas; pecíolo 0,9-1,4 cm compr., glabro; lâmina lanceolada a oblongo-elíptica, 5,2-8,2 × 2,5$3,4 \mathrm{~cm}$, ápice obtuso a arredondado, base cuneada, glabra em ambas as faces; nervuras laterais 810 pares, nervação secundária e terciária obscuras. Inflorescências com pedúnculos 2,5-3,5 cm, glomérulos 2-6, 8-15 mm diâm., invólucro 5-6 mm compr., truncado. Flores numerosas; cálice truncado, ca. $4 \times 3,5 \mathrm{~mm}$; corola creme-esverdeada, ca. 1,5 ×2-4 mm, 56-lobada; estames 5-6. Bagas globosas, verde claras, 5-7 ×4-6 mm; sementes ca. $4 \times 3 \mathrm{~mm}$.

Ocorre na região amazônica da Venezuela e nas Guianas, sendo que no Brasil ela é conhecida dos estados do Amazonas, Pará e Bahia. Na Reserva, foi encontrada apenas na floresta de baixio, com flores e frutos em setembro e fevereiro, e com frutos em junho (Campos \& Brito 1999: pág. 627, 629).

1.IX.1995 (fl fr) Ribeiro et al. 1686 (INPA K MO NY SPF); $16 . I I .1996$ (fl fr) Campos et al. 502 (INPA K MO NY); 5.VI.1996 (fr) Vicentini \& Assunção 1192 (INPA K MO).

\section{Sipanea Aubl.}

Ervas eretas ou decumbentes até subarbustos pequenos, hermafroditas. Ramos delgados. Estípulas interpeciolares, persistentes, arredondadas ou triangulares até partidas. Folhas opostas, sésseis ou pecioladas, decussadas. Inflorescências terminais e/ou axilares, paniculadas, cimosas ou reduzidas a 1-3-floras. Flores bissexuais, homostílicas; cálice 4-5(-6)-lobado; corola hipocrateriforme, alva a rosada, vilosa na região da fauce, 5(-6)-lobada, prefloração contorta; estames $5(-6)$, inseridos na região inferior ou mediana do tubo da corola, anteras dorsifixas; ovário 2-locular, óvulos muitos por lóculo; estigma 2-partido. Frutos capsulares, elipsóides a subglobosos, cartáceos, deiscência loculicida; sementes numerosas, angulosas.

Compreende cerca de 17 espécies, da América Central até Bolívia e Paraguai (Taylor et al. 2004). O hábito geralmente herbáceo, as 
flores rosadas vistosas, o tubo da corola estreito e hipocrateriforme, muitas vezes com um anel amarelo contrastando com os lobos alvos a rosados, a prefloração contorta e as pequenas cápsulas cartáceas com muitas sementes são alguns caracteres diagnósticos deste gênero.

\subsection{Sipanea pratensis Aubl., Hist. P1.} Guiane 1: 148. 1775.

Ervas ou subarbustos eretos, $20-50 \mathrm{~cm}$ alt. Ramos cilíndricos, seríceos ou hirsutos. Estípulas triangulares, 2-4 × $2 \mathrm{~mm}$, hirsutas. Folhas sésseis a curto pecioladas; pecíolo 1$2 \mathrm{~mm}$ compr., hirsuto; lâmina estreitolanceolada a lanceolada, 1,7-5,2 ×4-12 mm, ápice agudo a acuminado, base atenuada, hirsuta principalmente nas nervuras em ambas as faces; nervuras laterais 4-6 pares. Inflorescências terminais, em dicásios modificados, 3,5-4,3 cm compr. Flores subsésseis; cálice 5(-6)-lobado, lobos estreitamente triangulares, mais longos que o tubo do cálice, $6-8 \times 1,5-2 \mathrm{~mm}$, hirsutos externamente, glabros internamente; corola 5(-6)-lobada, hipocrateriforme, estreita, rosada, $15-30 \times 1-2 \mathrm{~mm}$, região da fauce densamente pilosa com tricomas amarelos, lobos obtusos ou arredondados. Cápsulas elipsóides, 6-9 × 1,5-2 mm, membranáceas, hirsutas; sementes pequenas, irregulares, reticuladas, 0,5-0,8 $\mathrm{mm}$ compr.

Ocorre na América do Sul, Guianas, Venezuela, Peru, Colômbia, Bolívia e Brasil, no Amapá e Amazonas. Entre os materiais coletados na Reserva Ducke foram observados espécimes hexâmeros, o que até então não tinha sido referido para o gênero, e existe necessidade de aprofundar os estudos desta população para definir se eles se encaixam dentro da variabilidade da espécie, que apresenta uma ampla distribuição geográfica acompanhada por grande variabilidade morfológica, tendo sido descritas diversas variedades e formas (Steyermark 1974; Taylor et al. 2004). Na Reserva, ocorre preferencialmente em áreas perturbadas, e floresce e frutifica de dezembro a abril (Campos \& Brito 1999: pág. 627, 630).
28.IV.1988 (fl fr) Ramos 1890 (INPAK MO NY SPF); 9.XII.1994 (fl fr) Costa \& Nascimento 43 (INPA K SPF); 22.III.1996 (fl) Campos et al. 580 (INPA MO NY SPF).

\section{Spermacoce L.}

Ervas hermafroditas anuais ou perenes até pequenos subarbustos, eretos ou prostrados. Ramos quadrangulares ou aplanados. Estípulas unidas aos pecíolos através de uma bainha desenvolvida, apicalmente fimbriada ou setosa, persistente. Folhas opostas ou às vezes pseudoverticiladas (ou seja, folhas dos ramos axilares não expandidos agrupadas com as folhas do ramo), sésseis ou subsésseis, decussadas. Inflorescências em glomérulos axilares e/ou terminais. Flores bissexuais, homostílicas ou distílicas; cálice (2-)4(-8)-denteado ou raro ausente; corola infundibuliforme ou salverforme, alva ou rosada, internamente pubescente ou glabra, lobos 4, prefloração valvar; estames (3)-4, inseridos na fauce da corola, anteras dorsifixas, inclusas ou geralmente exsertas; ovário 2-locular, óvulos 1 por lóculo; estigma capitado ou bipartido. Frutos capsulares, elipsóides a subglobosos, cartáceos a papiráceos, deiscência septicida ou com uma metade deiscente e a outra indeiscente; sementes oblongas a elipsóides, reticuladas, com um sulco ventral.

Gênero pantropical que apresenta cerca de 250 espécies, muitas delas ocorrendo na América tropical. Atualmente este gênero é frequentemente circunscrito incluindo os gêneros Borreria e Hemidiodia (Taylor et al. 2004). Spermacoce é semelhante a Diodia, onde os dois mericarpos do fruto são indeiscentes, e com Mitracarpus, cuja cápsula abre-se através de uma circuncisão subapical. Algumas características úteis na distinção deste gênero são o pequeno porte, hábito herbáceo, estípulas setosas com a bainha unida aos pecíolos, folhas subsésseis, as inflorescências em glomérulos pequenos axilares e as cápsulas geralmente deiscentes com duas sementes por fruto. 
Chave para as espécies de Spermacoce na Reserva Ducke

1. Inflorescências sempre axilares; folhas ligeiramente escabrosas na face adaxial, $4,1-7,1 \times$ 0,9-1,9 cm, cápsulas com um mericarpo deiscente e outro indeiscente .........3. S. ocymifolia

1'. Inflorescências tanto terminais como axilares; folhas lisas, $2-2,5 \times 0,9-1,1 \mathrm{~cm}$ ou $1-5,5 \times 0,1-$ $0,6 \mathrm{~cm}$, cápsulas com ambos mericarpos deiscentes.

2. Folhas 2-2,5 $\times 0,9-1,1 \mathrm{~cm}$, elípticas; ervas delicadas

2. S. exilis

2 '. Folhas $1-2,8 \times 0,1-0,6 \mathrm{~cm}$, estreitamente elípticas ou lineares; ervas robustas a subarbustos.

3. Inflorescências terminais hemisféricas; cálice 4-lobado, 2-3 mm compr...... 1. S. capitata

3'. Inflorescências terminais globosas; cálice bilobado, $1-2 \mathrm{~mm}$ compr. ....... 4. S. verticillata

34.1 Spermacoce capitata Ruiz \& Pav., Fl. Peruv. 1: 61, t. 91, fig. b. 1798.

Borreria capitata (Ruiz \& Pav.) DC., Prodr. 4: 545. 1830.

Ervas eretas ou subarbustos, $30-50 \mathrm{~cm}$ alt., pouco ramificados. Ramos cilíndricos ou ligeiramente quadrangulares, escamosos, glabros. Estípulas ca. $4 \times 2-3 \mathrm{~mm}$, glabras, setas 4-9. Folhas pseudoverticiladas, sésseis; lâmina estreito-elíptica ou linear, $1-2,1 \times 0,1-0,6 \mathrm{~cm}$, ápice agudo acuminado, base aguda, glabra em ambas as faces; nervação secundária obscura. Inflorescências em glomérulos terminais, 6$8 \mathrm{~mm}$ compr. Flores com cálice 4-lobado, lobos estreitos, ciliados, 2-3 ×0,5-1 mm; corola 4-6 $\times 1-1,5 \mathrm{~mm}$; anteras azuladas. Cápsulas com ambos mericarpos deiscentes, 1,8-2,2 mm compr.; sementes oblongas, reticuladas, $0,4-0,7 \mathrm{~mm}$ compr.

Ocorre no México, Caribe, América Central eAmérica do Sul até Bolívia eArgentina. No Brasil é amplamente distribuída. Na Reserva, ocorre em áreas perturbadas, foi coletada com flores e frutos em março e abril, mas provavelmente floresce e frutifica durante a maior parte do ano (Campos \& Brito 1999: pág. 627, 630). 15.III.1996 (fl fr) Costa \& Lohmann 479(INPANY SPF); 27.IV.1995 (fl fr) Costa et al. 216 (INPA K NY SPF).

34.2 Spermacoce exilis (L.O. Williams) C.D. Adams exW.C. Burger \& C.M. Taylor, Fieldiana, Bot., n.s. 33: 316. 1993.

Borreria exilis L.O. Williams, Phytologia 28: 227. 1974.

Borreria repens DC., Prodr. 4: 544. 1830.

Spermacoce mauritiana Gideon, Kew Bull. 37: 547. 1983.

Ervas prostradas ou eretas, até $30 \mathrm{~cm}$ alt., pouco ramificadas. Ramos delgados, quadrangulares, pubescentes. Estípulas 1,5-4 $\times 1,5-6 \mathrm{~mm}$, esparsamente pubescentes, com 5-9 setas desiguais. Folhas opostas, subsésseis; lâmina lanceolada a elíptica, 2-2,5 $\times 0,9-1,1 \mathrm{~cm}$, ápice agudo, base cuneada, glabra em ambas as faces ou a margem esparsamente pubérula; nervuras laterais 4-6 pares. Inflorescências terminais e axilares, paucifloras, 2-4 $\mathrm{mm}$ compr. Flores muito pequenas; cálice bilobado, 0,5-1 mm compr.; corola alva, 1-2 mm compr. Cápsulas com ambos mericarpos deiscentes, $0,8-1,2 \times 1-2$ $\mathrm{mm}$; sementes amareladas ou castanhas, oblongas, foveoladas, $0,6-0,9 \mathrm{~mm}$ compr.

Ocorre do México e Caribe até a América do Sul e em varias regiões paleotropicais (Taylor et al. 2004). Na Reserva, ocorre em áreas alteradas; foi coletada com flores em março, mas provavelmente floresce e frutifica durante todo o ano (Campos \& Brito 1999: pág. 627, 630). 16.III.1995 (fl) Costa et al. 160 (INPA MO NY SPF).

34.3 Spermacoce ocymifolia Willd. ex Roem. \& Schult., Syst. veg. 3: 530. 1818.

Hemidiodia ocimifolia (Willd. ex Roem. \& Schult.) K. Schum., Fl. bras. 6(6): 30, t. 72. 1889.

Didia ocymifolia (Willd. ex Roem. \& Schult.) Bremek., Recueil Trav. Bot. Néerl. 31: 305. 1934.

Borreria ocymifolia (Willd. ex Roem. \& Schult.) Bacigalupo \& E.L. Cabral, Opera Bot. Belg. 7: 307. 1996.

Ervas eretas ou subarbustos, $0,5-1 \mathrm{~m}$ alt. Ramos geralmente quadrangulares na base, distalmente cilíndricos, esparsamente pubescentes, fistulosos. Estípulas 6-12×3-5 mm, hirtelas, com 6-8 setas desiguais. Folhas opostas, subsésseis; lâmina estreito-lanceolada, lanceolada a elíptica, 
4,1-7,1 × 0,9-1,9 cm, ápice agudo a longoacuminado, base atenuada a decurrente, margem ligeiramente revoluta, glabra ou pubérula, ligeiramente escabrosa na face adaxial; nervuras laterais 7-9 pares, geralmente impressas na face adaxial. Inflorescências em glomérulos axilares, paucifloros, 5-7 mm compr. Flores com cálice 4-lobado, lobos triangulares, ciliados, ca. $2 \times 1 \mathrm{~mm}$; corola alva, $3-5 \mathrm{~mm}$ compr., 4-lobada, lobos esparsamente pilosos. Cápsulas oblongas, com um dos mericarpos indeiscente e o outro deiscente na face adaxial, basalmente curto-estipitadas, 5-8 × 1-1,5 mm; sementes plano-convexas, foveoladas, com sulco longitudinal adaxial.

Apresenta ampla distribuição geográfica, ocorrendo desde o México, América Central, e o Caribe até o Paraguai. Na Reserva ocorre em grandes populações, principalmente em áreas abertas e perturbadas; foi coletada florescendo e frutificando em janeiro e março mas provavelmente floresce e frutifica durante o ano todo (Campos \& Brito 1999: pág. 630). 29.III.1996 (fl fr) Campos 585 (INPA MO NY SPF); 17.I.1995 (fl fr) Costa et al. 100 (INPAKMO NYSPF).

34.4 Spermacoce verticillata L., Sp. Pl. 102. 1753.

Fig. 31

Borreria verticillata (L.) G. Meyer, Prim. Fl. Esseq. 83. 1818.

Ervas eretas ou subarbustos, até $50 \mathrm{~cm}$ alt., ramificados. Ramos cilíndricos ou ligeiramente quadrangulares, glabros ou híspidulos. Estípulas 2-7×3 mm, hispídulas ou glabras, setas 5-6. Folhas pseudoverticiladas, subsésseis; lâmina estreito-elíptica ou linear, 1,5$5,5 \times 0,1-0,6 \mathrm{~mm}$, ápice agudo acuminado, base aguda, glabra ou híspida em ambas as faces; nervação secundária obscura. Inflorescências em glomérulos terminais e às vezes axilares, 4-8 mm compr. Flores com cálice bilobado, lobos estreitos, $1-2 \times 0,5-1 \mathrm{~mm}$; corola $1-3 \times$ $1 \mathrm{~mm}$. Cápsulas com ambos mericarpos deiscentes, 1,5-2 mm compr.; sementes oblongas, foveoladas.

Possui ampla distribuição geográfica, ocorrendo do sul dos Estados Unidos ao sul América do Sul e também no Velho Mundo
(Taylor et al. 2004). Na Reserva, ocorre em áreas alteradas; foi coletada com flores em janeiro e abril, mas provavelmente floresce e frutifica durante ano inteiro (Campos \& Brito 1999: pág. 627, 630).

29.IV.1994 (fl) Ribeiro et al. 1298 (INPA MO SPF); 3.I.1995 (fl) Costa \& Silva 56 (INPA K MO SPF).

\section{Tocoyena Aubl.}

Arbustos, arvoretas ou árvores hermafroditas. Ramos cilíndricos, às vezes fistulosos. Estípulas interpeciolares ou às vezes unidas ao redor do caule, triangulares, persistentes. Folhas opostas ou ternadas, pecioladas, decussadas. Inflorescências terminais, corimbosas, capitadas ou cimosas. Flores bissexuais, vistosas, odoríferas, homostílicas; cálice 5-6-lobado; corola hipocrateriforme, alva, creme ou amarela, com tubo bem desenvolvido, geralmente glabra no interior, 56-lobada, prefloração contorta; estames 5-6, inseridos na região da fauce da corola, anteras dorsifixas; ovário 2-locular, óvulos numeroso em cada lóculo; estigma 2-partido. Frutos bacáceos, globosos a subglobosos, carnosos, bem desenvolvidos, negros ou azulados; sementes numerosas, comprimidas, envolvidas numa polpa gelatinosa.

Apresenta cerca de 22 espécies, distribuídas na região tropical da América Central até o Paraguai (Prado 1987; Taylor $e t$ $a l$. 2004). Suas principais características são o tubo da corola reto e alongado, as inflorescências terminais e o fruto globoso terminal, geralmente solitário. Posoqueria é um gênero afim a Tocoyena, porém apresenta flores zigomorfas com prefloração imbricada e sementes angulosas a subglobosas.

35.1 Tocoyena longiflora Aubl., Hist. Pl. Guiane 1; 131, t. 50. 1775.

Arvoretas até $7 \mathrm{~m}$ alt., $6 \mathrm{~cm}$ de diâm. Tronco circular, base acanalada. Ritidoma marrom, estriado, com anéis transversais; exterior da casca marrom, ca. $1 \mathrm{~mm}$ de espessura; casca internamente amarela. Ramos levemente quadrangulares, estriados, glabros, raramente fistulosos. Estípulas interpeciolares, 
triangulares, 1-1,2 $\times 5-7 \mathrm{~cm}$, agudas ou aristadas. Folhas opostas, pecioladas; pecíolo glabro a esparsamente pubérulo, $1-3,5 \mathrm{~cm}$ compr.; lâmina lanceolada a elíptica, 37-60× $12-15,5 \mathrm{~cm}$, ápice agudo a acuminado, base obtusa a cuneada, glabra em ambas as faces ou hirtela nas nervuras da face abaxial; nervuras laterais 12-13 pares. Inflorescências fasciculadas, multifloras, $1-2 \mathrm{~cm}$ compr. (sem flores), pedúnculo 0,3-1 cm compr. Flores com cálice denteado, lobos 2-4 mm compr., agudos; corola creme-amarelada, glabra, tubo 18-23 $\times 0,2-0,3 \mathrm{~cm}$, lobos elípticos, ca. $2 \times 0,8 \mathrm{~cm}$. Bagas globosas, 6-6,5 $\times 3,5 \mathrm{~cm}$, glabras.

Ocorre na Guiana Francesa e no Brasil, nos estados do Amazonas, Pará, Maranhão e Bahia (Prado 1987). Na Reserva Ducke, é rara e foi coletada na floresta de platô, apenas estéril até o momento (Campos \& Brito 1999: pág. 640, 647). VIII.1970 (est) Rodrigues \& Coelho 1246 (INPA).

\section{Warszewiczia Klotzch}

Árvores ou arbustos hermafroditas. Ramos cilíndricos ou tetragonais, às vezes com exsudado resinoso. Estípulas interpeciolares, triangulares ou lanceoladas, decíduas, às vezes torcidas. Folhas opostas, pecioladas, decussadas. Inflorescências terminais e às vezes nas axilas das folhas distais, paniculadas ou tirsóides, freqüentemente com eixos racemosos ou espiciformes. Flores bissexuais, protogínicas; cálice truncado a 5-denteado, em umas flores com um dos lobos freqüentemente expandido numa lâmina petalóide (ou calicofilo) alvo, esverdeado, vermelho ou arroxeado; corola infundibuliforme, alva, amarelada ou avermelhada, vilosa na fauce, 5-lobada, prefloração imbricada; estames 5, inseridos na porção mediana da corola, anteras dorsifixas, exsertas; ovário 2-locular, óvulos muitos por lóculo; estigma 2-partido. Frutos capsulares, globosos, subglobosos ou turbinados, lenhosos ou cartáceos, deiscência septicida; sementes numerosas, comprimidas ou angulosas.

Compreende cerca de seis ou sete espécies neotropicais (Taylor et al. 2004). É caracterizado por apresentar flores pequenas com um dos lobos do cálice expandido numa lâmina petalóide, aqui referida como calicofilo, estípulas interpeciolares e decíduas e frutos capsulares pequenos de deiscência septicida.

36.1 Warszewiczia schwackei K. Schum., Fl. bras. 6(6): 219, t. 115. 1889.

Fig. 3k

Árvores ca. $15 \mathrm{~m}$ alt., $10-15 \mathrm{~cm}$ diâm. Tronco acanalado, base acanalada. Ritidoma marrom-avermelhado, fissurado, frágil; exterior da casca marrom, 2-3 $\mathrm{mm}$ de espessura; casca internamente creme, 1,5-2 mm de espessura; anel marrom entre a casca internamente e o alburno; alburno amarelado. Ramos ligeiramente quadrangulares, longitudinalmente sulcados, escamosos, ferrugíneo-tomentosos. Estípulas 1-2×0,6-1 cm, ferrugíneo-tomentosas, agudas a acuminadas. Folhas pecioladas; pecíolo 23,5 cm compr., ferrugíneo-tomentoso; lâmina oval a lanceolada, $21-35 \times(10,5-) 15,5-19,5 \mathrm{~cm}$, ápice agudo ou acuminado, base atenuada ou subcordada, glabra na face adaxial ou com as nervuras pubérulas, pubérula na face abaxial; nervuras laterais 13-16(-19) pares. Inflorescências multifloras, $13-30 \mathrm{~cm}$ compr., com ramos espiciformes, ferrugíneo-tomentosos. Flores sésseis em glomérulos; cálice tomentoso, 1-2 mm compr., lobos ciliados, calicofilo lanceolado, alvo-esverdeado, 1,5-5× $0,5-3 \mathrm{~cm}$; corola alva, $2-2,5 \times 1-2 \mathrm{~mm}$, pubérula externamente, com um anel de tricomas internamente. Cápsulas obovóides, tomentosas, ca. $2 \times 2 \mathrm{~mm}$; sementes $0,5-1 \mathrm{~mm}$ compr.

Ocorre nas florestas tropicais do Peru, Colômbia, Venezuela, Equador e Brasil, na região amazônica. Na Reserva, ocorre na floresta de vertente e de platô, com flores e frutos de fevereiro a julho (Campos \& Brito 1999: pág. 643, 647).

21.VII.1994, (fr) Ribeiro et al. 1347 (INPAMO NY); 15.II.1996 (fl fr) Campos et al. 494 (INPA MO NY SPF); 22.VI.1994 (fr) Hopkins et al. 1414 (INPA MO NY SPF); $10 . I I .1996$ (fl fr) Campos et al. 474 (INPA MO NY SPF); 25.V.1995, (fr) Vicentini \& Silva 976 (INPA MO NY SPF); 21.III.1995 (fr) Nascimento et al. 768 (INPA MO NY).

Material adicional examinado: BRASIL. AMAZONAS: Manaus, 10.II.1933 (fl) Ducke 24379 (IAN K); $31 . I I I .1932$ (fr) Ducke 24380 (IAN K). 


\section{Agradecimentos}

As autoras agradecem aos diversos indivíduos e instituições que auxiliaram tanto na fase de trabalho de campo como de estudos de herbário relativos à compilação da Flora da Reserva Ducke, especialmente Lucia Lohmann, Brian Boom, Claes Persson, e os curadores dos herbários F, INPA, K, MO e NY; e em particular ao Valdely Kinupp, por ter contribuído generosamente com um grande volume de informações relatives às Rubiaceae da Reserva; ao Paulo Ormindo pela finalização das pranchas; à voluntária Carla Gleeson, que localizou exsicatas no Herbário K; ao Mike Hopkins, pela sua contribuição no avanço deste projeto e por conferir e compilar informações pertinentes ao projeto; e à Rafaela Campostrini Forzza, pela dedicação e entusiasmo com que vem apoiando a publicação dos tratamentos de famílias da Flora. 